\title{
Republic of Korea: Report on Observance of Standards and Codes_Data Module
}

This Report on Observance of Standards and Codes on Data Module for the Republic of Korea was prepared by a staff team of the International Monetary Fund as background documentation for the periodic consultation with the member country. It is based on the information available at the time it was completed on July 8,2010. The views expressed in this document are those of the staff team and do not necessarily reflect the views of the government of the Republic of Korea or the Executive Board of the IMF.

The Response by the Authorities to this report, and the Detailed Assessments Using the Data Quality Assessment Framework (DQAF) are also included.

The policy of publication of staff reports and other documents by the IMF allows for the deletion of market-sensitive information.

Copies of this report are available to the public from

International Monetary Fund • Publication Services

$70019^{\text {th }}$ Street, N.W. $\bullet$ Washington, D.C. 20431

Telephone: (202) 623-7430 • Telefax: (202) 623-7201

E-mail: publications@imf.org Internet: http://www.imf.org

\section{International Monetary Fund Washington, D.C.}


INTERNATIONAL MONETARY FUND

REPUBLIC OF KOREA

\title{
Report on the Observance of Standards and Codes (ROSC)—Data Module Volume I
}

\author{
Prepared by the Statistics Department \\ Approved by Adelheid Burgi-Schmelz and Anoop Singh
}

July 8, 2010

The Report on the Observance of Standards and Codes (ROSC)—Data Module provides an updated assessment of Korea's macroeconomic statistics against the Special Data Dissemination Standard (SDDS) complemented by an assessment of data quality based on the IMF's Data Quality Assessment Framework (DQAF) July 2003. The DQAF lays out internationally accepted practices in statistics, ranging from good governance in data-producing agencies to practices specific to datasets.

The datasets covered in this report are national accounts, consumer and producer price indices, government finance, monetary and balance of payments statistics. The agencies that compile the datasets assessed in this report are the Bank of Korea, the Ministry of Strategy and Finance, and Statistics Korea.

The datasets to which this report pertains can be accessed in print and on the Internet:

Bank of Korea (http://www.bok.or.kr)

Ministry of Strategy and Finance (http://www.mosf.go.kr)

Statistics Korea (http://kostat.go.kr)

This report is based on information provided prior to and during a staff mission from December 9-22, 2009 and publicly available information. The mission team comprised Mr. Enoch (Head), Mr. Harutyunyan and Ms. Mesias (STA), Messrs. Collins, Gorter, and Harvey (Experts), and Ms. George (Administrative Assistant, STA). 
Acronyms. 3

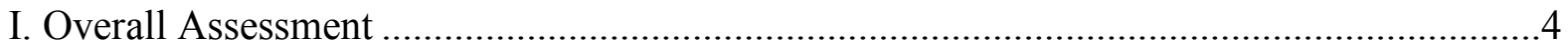

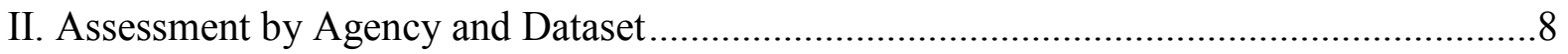

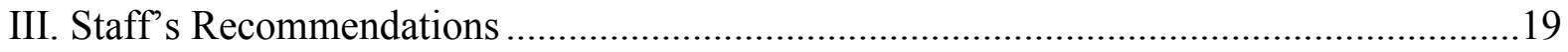

Tables

1. DQAF July 2003-Summary Results .9

2a. Assessment of Data Quality —Dimensions 0 and 1-Bank of Korea...............................10

2b. Assessment of Data Quality—Dimensions 0 and 1-Statistics Korea..............................11

2c. Assessment of Data Quality—Dimensions 0 and 1-Ministry of Strategy and Finance ..12

3a. Assessment of Data Quality-Dimensions 2 to 5-National Accounts ............................13

3b. Assessment of Data Quality—Dimensions 2 to 5-Consumer Price Index ........................14

3c. Assessment of Data Quality-Dimensions 2 to 5-Producer Price Index .........................15

3d. Assessment of Data Quality-Dimensions 2 to 5-Government Finance Statistics ........16

3e. Assessment of Data Quality—Dimensions 2 to 5-Monetary Statistics...........................17

3f. Assessment of Data Quality—Dimensions 2 to 5-Balance of Payments Statistics .........18

Appendixes

I. Practices Compared to the SDDS Coverage, Periodicity, and Timeliness of Data 


\section{ACRONYMS}

1993 SNA

2008 SNA

BOK

BOP

BPM5

ВРМ6

COFOG

COICOP

CPI

CPIM 2004

CPS

DACOS

DCS

DQAF

DSBB

ECOS

ESD

f.o.b.

FEIS

FESF

GDP

GFS

GFSM 1986

GFSM 2001

HIES

IIP

ILO

IMF

ISIC

KOSIS

KOSTAT

KSIC

MAA

MFSM

MEST

MOSF

MOPAS

ODCs

OECD

PIM

PPI

PPIM

ROSC

SDDS

STA
System of National Accounts, 1993

System of National Accounts, 2008

Bank of Korea

Balance of Payments

Balance of Payments Manual, Fifth Edition

Balance of Payments and International Investment Position Manual, Sixth Edition

Classifications of the Functions of Government

Classification of Individual Consumption by Purpose

Consumer Price Index

Consumer Price Index Manual, 2004

Consumer Price Survey

Data Collection System

Depository Corporations Survey

Data Quality Assessment Framework

Dissemination Standards Bulletin Board

Economic Statistics System, Bank of Korea

Economic Statistics Department, Bank of Korea

Free on board

Foreign Exchange Information System

Foreign Exchange Stabilization Fund

Gross Domestic Product

Government Finance Statistics

A Manual on Government Finance Statistics, 1986

Government Finance Statistics Manual, 2001

Household Income and Expenditure Survey

International Investment Position

International Labor Organization

International Monetary Fund

International Standard Industrial Classification

Korean Statistical Information System

Statistics Korea

Korean Standard Industrial Classification

Monetary Authorities' Account

Monetary and Financial Statistics Manual, 2000

Ministry of Education, Science, and Technology

Ministry of Strategy and Finance

Ministry of Public Administration and Security

Other Depository Corporations

Organization for Economic Co-operation and Development

Perpetual Inventory Method

Producer Price Index

Producer Price Index Manual, 2004

Report on the Observance of Standards and Codes

Special Data Dissemination Standard

Statistics Department, IMF 


\section{Overall ASSESSMent}

1. Korea's statistics are generally of a high quality, and reflect a significant improvement since the last Report on the Observance of Standards and Codes (ROSC) Data Module for Korea in 2001, which itself recognized substantial improvement over the previous few years. This momentum has been reinforced by legal reform, in particular the most recent revisions to the Bank of Korea Act in February 2008, and the Statistics Act in April 2009. The responsibility for macroeconomic statistics is more heavily located in the central bank, the Bank of Korea (BOK), than is the case in many countries, with the BOK holding responsibility for national accounts, producer price indices (PPI), monetary, and balance of payments (BOP) statistics. Statistics Korea (KOSTAT) is responsible for the consumer price index $(\mathrm{CPI})$, reflecting Korea's inflation targeting policy regime and the undesirability of the central bank to be seen to be responsible for compiling the indicator that it is mandated to target. The compilation of government finance statistics (GFS) is decentralized, with central government falling to the Fiscal Policy Bureau of the Ministry of Strategy and Finance (MOSF), while data on local governments are compiled by the Ministry of Administration and Security (MOPAS) and the Ministry of Education, Science and Technology (MEST).

2. Korea subscribed to the Special Data Dissemination Standard (SDDS) of the International Monetary Fund (IMF) in September 1996 and started posting its metadata on the Dissemination Standards Bulletin Board (DSBB) in March 1998. Korea is in observance of the SDDS, meeting the specifications for coverage, periodicity, timeliness, and the dissemination of advance release calendars. The country uses flexibility options on the timeliness of the general government operations data and the depository corporations survey (DCS). On the other side, it exceeds the SDDS requirements for timeliness and periodicity in some areas. Appendix Table I provides an overview of Korea's dissemination practices compared to the SDDS.

3. This Data ROSC contains the following main observations. Korean statistics are of a high standard and have improved substantially since the 2001 ROSC Data Module. Plans in train will further establish the strength of the Korean statistical system. In all compiling agencies there is an appropriate legal structure, as well as strong provisions to ensure the integrity of the data. While largely sound, nearly all datasets have some room for improvement. As regards national accounts, improvements could be made in a few statistical techniques. The CPI is sound, although KOSTAT may wish to consider whether to more fully integrate measures relating to owner-occupied housing; also, an unbiased approach in the imputation of out-of-season prices should be adopted. The PPI could be improved by taking the price movements of similar products in the event that a particular price is missing, rather than simply taking the most recent observation. For GFS, until very recently, a key issue was improving accessibility to the data and metadata for measures other than central government. For monetary statistics, the BOK's foreign currency denominated assets and liabilities are revalued only twice a year, as opposed to revaluation at least monthly, which is common internationally. Finally, BOP statistics could show improvements as regards scope, classification, and basis of recording practices. 
4. The compilation and dissemination of statistics are at a key juncture at this time. There are ambitious programs, for instance, to migrate to the Balance of Payments and International Investment Position Manual, Sixth Edition (BPM6) as from 2010, the Government Finance Statistics Manual, 2001 (GFSM 2001) in 2012, and the System of National Accounts, 2008 (2008 SNA) in 2014, and to further enhance the quality of the websites of the compiling agencies. These could help bring Korea towards the cutting edge of statistical achievement. On the other hand, there still remain a range of problems on data accessibility, and progress to the new methodologies could lead to data inconsistencies during the transition if not fully coordinated. It would be helpful to have close collaboration among the compiling agencies, and with users both inside and outside the official sector, to ensure the migration programs can move ahead smoothly and effectively. This could well be a focus for the work of the National Statistics Committee (see below) over the coming years. And, as noted above, Korea still maintains two flexibility options in the SDDS from which it could seek to graduate. The compiling agencies may consider using the opportunity of the prospective 2010 rebasing of national accounts, CPI, and PPI, to effect desired changes smoothly in those datasets.

5. Section IV of this report provides some summary recommendations for addressing these issues. Some of the recommendations in this report can be implemented very quickly; others may take staff and financial resources.

6. In applying the IMF's Data Quality Assessment Framework (DQAF) July 2003, the remainder of this section presents the mission's main findings. The findings are presented at the level of the DQAF's quality dimensions, by agency for the first two dimensions, and across datasets for the remaining four.

\section{Pre-requisites of quality and assurances of integrity}

- $\quad$ National accounts, PPI, and monetary and BOP statistics are compiled by the Bank of Korea in accordance with Article 86 of the Bank of Korea Act which states that "The Bank of Korea may, when necessary for the formulation of its monetary and credit policies, collect and compile statistics on money and banking, public finances, prices, wages, production, the balance of payments, and other basic economic statistical series and conduct economic research and for such purposes request any materials or information from government organizations and any juristic or individual person." Article 42 of the Banking Act states the terms under which commercial and specialized banks are to submit balance-sheet accounts to the BOK and that the BOK may publish the reported data; and the Foreign Exchange Transactions Act and bylaws provide authority for the BOK to collect information on international transactions for the purposes of compiling the BOP. The BOK is an independent agency, protected from interference from government under the provisions of the Bank of Korea Act. The present management has set high store on enhancing this central bank independence. In addition, the Statistics Act specifies all aspects of the production of statistics in Korea. Article 15 describes conditions for the designation of statistics collecting agencies; Article 18 governs conditions for the collection; and Article 27 describes conditions for dissemination of statistics. As a designated agency, the BOK is governed in its statistical work also by other provisions of the 
Statistics Act. Resources are commensurate for the BOK to carry out its statistical functions, which are organized within a dedicated Economic Statistics Department (ESD). The institution seeks to maintain high levels of transparency in the compilation and dissemination of its statistics, with public explanation of the terms and conditions under which the statistics are collected, compiled, and disseminated, no prior internal government access, and advance notice of major changes. There is heavy emphasis on professionalism among the staff. All BOK staff are bound by the Bank of Korea Act, section 42, which specifies that they should not divulge confidential matters to outsiders. Similar provisions are contained in Article 20 of the Articles of Incorporation of the BOK, as well as in the Rules of Employment, the Code of Conduct, the Code of Ethics and Morals, and the Guidelines of Compilation and Dissemination of Statistics of the BOK and the Foreign Exchange Transactions Act of the MOSF. All staff must take a written oath to commit to follow the Code of Conduct.

- $\quad$ The Statistics Act establishes KOSTAT as the overarching statistical agency in the country, with powers to designate the conduct of statistical exercises or to designate other agencies to provide specified statistics. Under the Statistics Act a high-level deliberative body, the National Statistics Committee, has been established under the Minister of Strategy and Finance. KOSTAT is mandated to compile the CPI, and has designated the conduct of a consumer price survey (CPS) and a household income and expenditure survey (HIES) in order to be able to fulfill its mandate. KOSTAT is an independent agency, protected by the Statistics Act from outside interference. It has sole power to choose its statistical techniques and processes. A high emphasis is placed on professionalism, with all staff mandated to take 90 hours of training each year, and encouraged to prepare papers and attend international conferences. The Statistics Act requires the Commissioner to secure resources to carry out the agency's mandate: resources are broadly adequate. KOSTAT staff have to respect the confidentiality of the statistics. There is no pre-release to government. There is also high emphasis on ethics, with newcomers having to attend a course on ethics, and existing staff having to retake the course twice a year.

- $\quad$ The Government Organization Act and subsequent Presidential Decrees specify the Fiscal Policy Bureau of the Ministry of Strategy and Finance as the agency to compile GFS. Local government data are the responsibility of the MOPAS and local education of the MEST. All ministries meet periodically in order to coordinate statistical activities. As agencies designated by KOSTAT, the staff are bound also by the Statistics Act. As noted above, this ensures the confidentiality of data. Resources are sufficient for the compilation and dissemination of the data, and there are high levels of professionalism. Relevance is ensured by frequent contacts with users. Quality awareness is high, with outside evaluations on key current topics. Efforts are being made also to provide explanations on the consolidated budget balance.

8. The methodological foundations of the statistics are generally sound, and reflect substantial improvement since the 2001 ROSC Data Module. National accounts are closely based on the System of National Accounts, 1993 (1993 SNA), although there could be some relatively minor improvements in scope. The CPI is appropriately based, although farming 
and fishing households are excluded and the "all items" index does not include estimates from housing owner-occupiers (these are shown separately). The PPI too has an appropriate overall structure in terms of concepts and definitions, as well as in scope, although the commodity classification could be better aligned with international standards. The compilation of GFS still follows the methodology of A Manual on Government Financial Statistics, 1986 (GFSM 1986), but a project to implement the GFSM 2001 framework and methodology is well advanced and is scheduled to result in the publication of fiscal source data in the GFSM 2001 format in 2012. A comprehensive new digital budget and accounting system has been introduced and new government accounting standards have been adopted. Most government units already apply accrual accounting and double bookkeeping (cash based data will continue to be available). Monetary statistics broadly follow the Monetary and Financial Statistics Manual, 2000 (MFSM), although the central bank survey does not identify the monetary base. In addition, the BOK values its financial assets and liabilities at book value and revalues foreign currency assets and liabilities only twice a year. The BOK intends that BOP statistics migrate to the BPM6 framework starting in 2010, making Korea among the first countries to do so. At present Korea follows the Balance of Payments Manual, Fifth Edition (BPM5) framework, although with a number of deviations: The scope of the transactions of enterprises through accounts held abroad and of reinvested earnings is partial; trade credits and short-term loans with affiliated entities are recorded under other investment; and income transactions are recorded on a payment basis. Data with an improved scope of the reinvested earnings data are to be disseminated in early 2010.

9. The accuracy and reliability of Korea's statistics have improved markedly in recent years. National accounts fulfill most of the requirements for accuracy and reliability, although a better method could be used to adjust original quarterly data to agree with annual estimates, and no specific estimates are included for the non-observed economy.

Depreciation should be replaced with consumption of fixed capital for sectors other than general government. The CPI appears accurate and reliable, although there is some scope for improvement in some specific statistical techniques. As regards the PPI, while it fulfils most of the requirements for accuracy and reliability, temporarily missing prices for both regular and seasonal products are imputed by simply repeating the most recent reported observation; also, elementary aggregate indices are currently calculated using the "Carli formula" as the simple arithmetic mean of price relatives, which has been shown to have potential bias. GFS, $\mathrm{BOP}$, and monetary statistics are accurate and reliable.

10. The serviceability of Korean statistics is in many cases excellent, with timeliness in many areas exceeding the requirements of the SDDS, in some cases by significant margins. BOP statistics are particularly strong in this regard, with timeliness better than SDDS requirements across many of the categories. Similarly, the timeliness of the CPI (as well as some labor market indicators) is much faster than required under the SDDS, with dissemination on the first business day in the month after the reference period. On the other hand, Korea maintains two flexibility options. It maintains a flexibility option for the timeliness of general government operations, which are usually disseminated one year after the reference period rather than the mandated two quarters and for the timeliness of the DCS, which is disseminated after six weeks rather than the mandated one month. There are a number of data gaps that users have indicated they would wish to see covered, in particular seasonal adjustment for the CPI. 
11. The accessibility of Korea's data at the moment is somewhat problematic, although there is potential for it to become excellent. Data-compiling agencies have put substantial efforts into developing their websites, so that data can be downloaded quickly and data manipulations performed easily. In the BOK, this is achieved through the Economic Statistics System (ECOS) database, and at KOSTAT through the Korean Statistical Information System (KOSIS). Users interviewed by the mission found the systems excellent. However, these systems encounter a problem that reportedly is affecting computers throughout Korea. These systems are based on access to Internet Explorer, which has a so-called "Active X" component that is intended to increase the speed of access to the site. Upon seeking to access ECOS or KOSIS, users are asked to download a dedicated locally-provided software program. While this software may be cutting-edge in terms of accessing and manipulating data, the "Active X" component on the browser apparently prevents the software crossing the firewalls that protect users, or leads to security warnings before the software can be downloaded. Both the BOK and KOSTAT are aware of this issue, and are working on addressing it. The BOK estimates that the problem will be resolved by 2012, when there will be state-of-the-art browser-free access, while KOSTAT has indicated that it expects that financing to address this will be available by the end of 2010, and it may take until 2013 to resolve. In the meantime, however, international users without direct assistance are restricted to obtaining data and metadata from print publications or by going through commercial vendors. Although the MOSF's GFS webpage does not use sophisticated browser software, until recently users were obliged to download a program to access the data. Until recently, the accessibility of the GFS lagged considerably behind that of the other datasets, which probably contributed to the concerns raised about GFS in the users' survey (see section III). Methodological descriptions of the GFS remain dispersed.

12. Section II provides a summary assessment by agency and dataset based on a four-part scale. A summary of the users' survey is shown in Section III. This is followed by staff recommendations in Section IV. Practices compared to the SDDS are summarized in Appendix I. The authorities' response to this report and a volume of detailed assessments are presented in separate documents.

\section{Assessment by AgenCy and Dataset}

13. An assessment of the quality of six macroeconomic datasets - national accounts, consumer price index, producer price index, government finance, monetary, and balance of payments statistics - was conducted using the DQAF, July 2003. In this section, the results are presented at the level of the DQAF elements and using a four-point rating scale (Table 1). Assessments of the prerequisites of data quality and the assurances of integrity (Dimensions " 0 " and " 1 " of the DQAF) are presented in Tables $2 \mathrm{a}-\mathrm{c}$. For the various datasets, the assessment of methodological soundness, accuracy and reliability, serviceability, and accessibility (Dimensions " 2 " to " 5 " of the DQAF) is shown in Tables 3a-f. The analysis was carried out on the basis of a self-assessment by the compiling agencies, discussions during the mission, and an informal users' survey. 
Table 1. Data Quality Assessment Framework July 2003—Summary Results

Key to symbols: $\mathrm{O}=$ Practice Observed; LO = Practice Largely Observed; LNO =Practice Largely Not Observed;

$\mathrm{NO}=$ Practice Not Observed; NA = Not Applicable

\begin{tabular}{|c|c|c|c|c|c|c|}
\hline $\begin{array}{lc} & \text { Datasets } \\
\text { Dimensions/Elements } & \\
\end{array}$ & $\begin{array}{l}\text { National } \\
\text { Accounts }\end{array}$ & $\begin{array}{l}\text { Consumer } \\
\text { Price Index }\end{array}$ & $\begin{array}{c}\text { Producer } \\
\text { Price Index }\end{array}$ & $\begin{array}{c}\text { Government } \\
\text { Finance } \\
\text { Statistics } \\
\end{array}$ & $\begin{array}{l}\text { Monetary } \\
\text { Statistics }\end{array}$ & $\begin{array}{c}\text { Balance of } \\
\text { Payments } \\
\text { Statistics } \\
\end{array}$ \\
\hline \multicolumn{7}{|l|}{ 0. Prerequisites of quality } \\
\hline 0.1 Legal and institutional environment & $\mathrm{O}$ & $\mathrm{O}$ & $\mathrm{O}$ & $\mathrm{O}$ & $\mathrm{O}$ & $\mathrm{O}$ \\
\hline 0.2 Resources & $\mathrm{O}$ & $\mathrm{O}$ & $\mathrm{O}$ & $\mathrm{O}$ & $\mathrm{O}$ & $\mathrm{O}$ \\
\hline 0.3 Relevance & $\mathrm{O}$ & $\mathrm{O}$ & $\mathrm{O}$ & $\mathrm{O}$ & $\mathrm{O}$ & $\mathrm{O}$ \\
\hline 0.4 Other quality management & $\mathrm{O}$ & $\mathrm{O}$ & $\mathrm{O}$ & $\mathrm{O}$ & $\mathrm{O}$ & $\mathrm{O}$ \\
\hline \multicolumn{7}{|l|}{ 1. Assurances of integrity } \\
\hline 1.1 Professionalism & $\mathrm{O}$ & $\mathrm{O}$ & $\mathrm{O}$ & $\mathrm{O}$ & $\mathrm{O}$ & $\mathrm{O}$ \\
\hline 1.2 Transparency & $\mathrm{O}$ & $\mathrm{O}$ & $\mathrm{O}$ & $\mathrm{O}$ & $\mathrm{O}$ & $\mathrm{O}$ \\
\hline 1.3 Ethical standards & $\mathrm{O}$ & $\mathrm{O}$ & $\mathrm{O}$ & $\mathrm{O}$ & $\mathrm{O}$ & $\mathrm{O}$ \\
\hline \multicolumn{7}{|l|}{ 2. Methodological soundness } \\
\hline 2.1 Concepts and definitions & $\mathrm{O}$ & $\mathrm{O}$ & $\mathrm{O}$ & $\mathrm{O}$ & $\mathrm{O}$ & $\mathrm{O}$ \\
\hline 2.2 Scope & $\mathrm{O}$ & $\mathrm{O}$ & $\mathrm{O}$ & $\mathrm{O}$ & $\mathrm{O}$ & LO \\
\hline 2.3 Classification/sectorization & $\mathrm{O}$ & $\mathrm{O}$ & LO & $\mathrm{O}$ & $\mathrm{O}$ & LO \\
\hline 2.4 Basis for recording & $\mathrm{O}$ & $\mathrm{O}$ & $\mathrm{O}$ & $\mathrm{O}$ & $\mathrm{LO}$ & $\mathrm{LO}$ \\
\hline \multicolumn{7}{|l|}{ 3. Accuracy and reliability } \\
\hline 3.1 Source data & $\mathrm{O}$ & $\mathrm{O}$ & $\mathrm{O}$ & $\mathrm{O}$ & $\mathrm{O}$ & $\mathrm{O}$ \\
\hline 3.2 Assessment of source data & $\mathrm{O}$ & $\mathrm{O}$ & $\mathrm{O}$ & $\mathrm{O}$ & $\mathrm{O}$ & $\mathrm{O}$ \\
\hline 3.3 Statistical techniques & LO & LO & LNO & $\mathrm{N} / \mathrm{A}$ & $\mathrm{O}$ & $\mathrm{O}$ \\
\hline $\begin{array}{l}\text { 3.4 Assessment and validation of intermediate } \\
\text { data and statistical outputs }\end{array}$ & $\mathrm{O}$ & $\mathrm{O}$ & $\mathrm{O}$ & $\mathrm{O}$ & $\mathrm{O}$ & $\mathrm{O}$ \\
\hline 3.5 Revision studies & LO & $\mathrm{O}$ & $\mathrm{O}$ & $\mathrm{N} / \mathrm{A}$ & $\mathrm{O}$ & $\mathrm{O}$ \\
\hline \multicolumn{7}{|l|}{ 4. Serviceability } \\
\hline 4.1 Periodicity and timeliness & $\mathrm{O}$ & $\mathrm{O}$ & $\mathrm{O}$ & LO & LO & $\mathrm{O}$ \\
\hline 4.2 Consistency & $\mathrm{O}$ & $\mathrm{O}$ & $\mathrm{O}$ & $\mathrm{LO}$ & LO & $\mathrm{O}$ \\
\hline 4.3 Revision policy and practice & $\mathrm{O}$ & $\mathrm{O}$ & $\mathrm{O}$ & $\mathrm{O}$ & $\mathrm{O}$ & $\mathrm{O}$ \\
\hline \multicolumn{7}{|l|}{ 5. Accessibility } \\
\hline 5.1 Data accessibility & LO & LO & LO & LO & LO & LO \\
\hline 5.2 Metadata accessibility & $\mathrm{O}$ & $\mathrm{O}$ & $\mathrm{O}$ & LO & $\mathrm{O}$ & $\mathrm{O}$ \\
\hline 5.3 Assistance to users & $\mathrm{O}$ & $\mathrm{O}$ & $\mathrm{O}$ & $\mathrm{O}$ & $\mathrm{O}$ & $\mathrm{O}$ \\
\hline
\end{tabular}

Practice observed: Current practices generally meet or achieve the objectives of DQAF internationally accepted statistical practices without any significant deficiencies. Practice largely observed: Some departures, but these are not seen as sufficient to raise doubts about the authorities' ability to observe the DQAF practices. Practice largely not observed: Significant departures and the authorities will need to take significant action to achieve observance. Practice not observed: Most DQAF practices are not met. Not applicable: Used only exceptionally when statistical practices do not apply to a country's circumstances. 
Table 2a. Assessment of Data Quality-Dimensions 0 and 1-Bank of Korea

\section{Prerequisites of quality}

Legal and institutional environment. Provisions for collecting and compiling BOP, monetary, PPI , and national accounts statistics, among others, are included in the Bank of Korea Act (last amended in February 2008) and the Statistics Act (last amended in April 2009). Article 86 of the Bank of Korea Act states the BOK may require government agencies, enterprises, and individuals to submit necessary data or information; and Article 87 states it has the right to request all information from banks and other financial intermediaries, although it has no powers to levy penalties itself. Article 15 of the Statistics Act states that KOSTAT may designate agencies for the purposes of developing statistics and Articles 18 and 27 govern conditions for the collection and dissemination of statistics respectively. This designation should be by legal provision. In the case of the BOP, the statistical reporting is ensured by the Foreign Exchange

Transactions Act (last amended in October 2009) and its corresponding bylaws. Data sharing and coordination among data-producing agencies is adequate. There are established rules to ensure that respondent's data are kept confidential and used only for statistical purposes.

Resources. Human, computing, and financing resources are adequate to collect, compile, and disseminate high-quality statistics. Measures to ensure efficient use of resources seem to be adequate.

Relevance. The BOK has formal mechanisms to consult data users about their information needs, such as a users' advisory committee for national accounts.

The ECOS website allows exchange of communication with users, among others.

The BOK participates in statistical meetings and seminars organized by international and regional organizations.

Other quality management. The BOK conducts an independent quality evaluation every five years and a quality self evaluation every year. In addition, it has established three committees on quality evaluation, source data improvement, and seasonal adjustment- to promote quality. The Audit Department of the BOK regularly reviews the consistency and accuracy of the published statistics along with the appropriateness of respective budgets and expenses. The BOK developed the Plan for Developing and Improving Economic Statistics in July 2009 and has participated in the Mid-long Term Development Plan for national statistics organized by KOSTAT.

\section{Assurances of integrity}

Professionalism. The terms and conditions under which the BOK produces and disseminates the BOP, monetary statistics, PPI, and national accounts datasets are in accordance with professional independence and follow strict technical criteria. The BOK encourages staff to participate in seminars and training programs arranged by domestic and international organizations in order to enhance statistical knowledge. When statistics are misinterpreted or misused, the $\mathrm{BOK}$ provides comments and clarifications.

Transparency. The BOK disseminates on its website information about the terms and conditions under which the statistical data are compiled and disseminated, including relevant laws. There is no internal government access to BOP, monetary, PPI, and national accounts statistics prior to their release to the public. The BOK statistical products area clearly identified as such. Important methodological changes are announced to the press and described in the national publications.

Ethical standards. The Rules of Employment, the Code of Conduct, and the Code of Ethics and Morals prescribe correct behavior of the BOK staff. The Code of Ethics and Morals is circulated each month to the BOK staff. Concerning statistical compilation procedures, guidelines for staff conduct are contained in the BOK's Guidelines on Compilation and Dissemination of Statistics. 


\section{Table 2b. Assessment of Data Quality-Dimensions 0 and 1-Statistics Korea}

\section{Prerequisites of quality}

Legal and institutional environment. The Statistics Act, last revised in April 2009, establishes KOSTAT as the overarching statistics-producing agency in the country. Under the Statistics Act a high-level deliberative body, the National Statistics Committee, has been established under the chairmanship of the Minister of Strategy and Finance. The Statistics Act tasks KOSTAT with the responsibility for compiling the CPI. Articles 15, 17 , and 18 specify that the agency designate designated agencies or statistics in order to achieve its mandates. Directive 10107 designates the CPS, and Directive 10106 the HI ES, to enable compilation of the CPI.

Article 32 of the Statistics Act specifies the duty of respondents to answer truthfully, while Article 33 mandates the confidentiality of the data. These provisions are widely disseminated and well known. Data sharing within KOSTAT and with other agencies is generally adequate.

Resources. Human, computing, and financing resources are adequate for the compilation and dissemination of the CPI. Measures are in place to ensure efficient use of the resources.

Relevance. When it revises the CPI, KOSTAT collects views on users' needs through meetings, surveys, and official documents. Between the five-year revision cycles, it has regular contacts with a wide group of users to ensure the continued relevance of the CPI. Staff regularly participate in the statistical meetings and seminars organized by the International Labor Organization, the Organization for Economic Cooperation and Development-Purchasing Power Parity (OECD-PPP), and the Ottawa Group.

Other quality management. Articles 9, 10, and 11 of the Statistics Law stipulate that the Commissioner of KOSTAT provide for examinations of the quality of statistics. In this connection, regular examinations of the quality of the statistics are conducted by the staff of KOSTAT and by outside experts. The resulting reports are publicly available on KOSTAT's website.

\section{Assurances of integrity}

Professionalism. The terms and conditions under which the CPI is produced are in accordance with professional independence and follow strict technical criteria. Staff are not influenced in the statistical techniques that they employ. All staff have 90 hours of mandatory training each year. KOSTAT maintains its own Statistical Training Institute to ensure that training is available to meet its needs. Staff are encouraged to prepare research papers; also, outside experts are invited to KOSTAT to give lectures. The Price Statistics Division monitors news media for stories about the CPI. It comments publicly on erroneous interpretations or misuse of statistics in the news media.

Transparency. Details of the CPI are posted on KOSTAT's website, as well as in news releases, and in monthly and annual reports. The public therefore has free access to this information. The weights and surveyed items of the CPI are revised every five years. No government agency has access to the products of KOSTAT before their release. The public is informed in bulletins, briefings, news releases, and on the website when major changes are introduced in methodologies, statistical techniques and sources, including weights and surveyed items Some of this information is in English, although more is provided in Korean.

Ethical standards. All staff receive training on ethics before they begin their jobs. This training is repeated twice a year. All staff have to follow KOSTAT's Code of Ethics, which is distributed to staff and posted on the premises. 


\section{Table 2c. Assessment of Data Quality-Dimensions 0 and 1-Ministry of Strategy and Finance}

\begin{tabular}{|c|c|}
\hline 0. Prerequisites of quality & 1. Assurances of integrity \\
\hline $\begin{array}{l}\text { Legal and institutional environment. The Government Organization } \\
\text { Act (1948) and subsequent Presidential Decrees attribute the responsibility } \\
\text { for compiling GFS to the Fiscal Policies Bureau in the MOSF. These } \\
\text { statistics are based on the budget realization data compiled and published } \\
\text { by the MOSF (for central government agencies), the MOPAS (for local } \\
\text { government agencies), and unpublished data compiled by the MEST (for } \\
\text { local education) as mandated by law. The three ministries meet regularly } \\
\text { for consultation. The GFS is approved by KOSTAT under the } \\
\text { Statistics Act. As such, the compiling agencies are bound by the Act's } \\
\text { provisions, for instance to keep individual reporters' data confidential. } \\
\text { Resources. Staff, computing, and financing resources are deemed } \\
\text { sufficient for the compilation of GFS. Staff are well trained. Annual policy } \\
\text { performance assessments conducted by the Prime Minister's office are } \\
\text { conducive for the efficient use of resources. } \\
\text { Relevance. The MOSF, MOPAS, and MEST work with other ministries, } \\
\text { experts, and researchers to review the usefulness of existing statistics and } \\
\text { to identify statistics that will be needed in the future. This is particularly } \\
\text { true with regard of the project to implement the GFSM 2001 and the } \\
\text { increased need for statistical information revealed by the global financial } \\
\text { crisis. } \\
\text { Other quality management. Quality awareness is high, among other } \\
\text { things as a result of the major reform projects that have stretched over } \\
\text { several years. In accordance with the Statistics Act, KOSTAT conducted } \\
\text { quality assessments of the consolidated fiscal balance (2007) and the } \\
\text { government bond statistics (2008). Efforts are being made also to provide } \\
\text { explanations on the consolidated budget balance. }\end{array}$ & $\begin{array}{l}\text { Professionalism. Although there is no formal provision supporting } \\
\text { professional independence, the compiling units' culture of professionalism } \\
\text { ensures independence. Statistics are compiled on the basis of objective } \\
\text { facts, derived from administrative records, and methodological rules. } \\
\text { Outside agencies do not interfere with the compilation process or the } \\
\text { dissemination of data. The MOSF comments on misinterpretations by the } \\
\text { National Assembly, the media, and others, generally through a press } \\
\text { release. To prevent misinterpretation or misuse of statistics, the MOSF } \\
\text { Public Relations Division reviews the media every day. } \\
\text { Transparency. All Acts and Presidential and Ministerial Decrees are } \\
\text { published in the Korean Official Gazette. The Government Accounting } \\
\text { Settlement Guidelines are also published and easily accessible. There is no } \\
\text { internal government access to statistics prior to their release. Statistics } \\
\text { disseminated in the form of a press release show the name of the } \\
\text { data-producing agency, agency's logo or emblem, and contact information } \\
\text { of staff in charge. The source of GFS released in other forms is also } \\
\text { clearly identified. } \\
\text { Ethical standards. MOSF staff are bound by the Code of Ethics for Civil } \\
\text { Servants and a specific Code of Conduct for MOSF officials. New or } \\
\text { transferred staff are educated in the codes of conduct when they join the } \\
\text { organization, and existing staff are periodically reminded of it through } \\
\text { workshops. }\end{array}$ \\
\hline
\end{tabular}




\begin{tabular}{|c|c|c|c|}
\hline 2. Methodological soundness & 3. Accuracy and reliability & 4. Serviceability & 5. Accessibility \\
\hline $\begin{array}{l}\text { Concepts and definitions. National accounts } \\
\text { are compiled according to the } 1993 \text { SNA. } \\
\text { Scope. Annual and quarterly Gross Domestic } \\
\text { Product (GDP) are compiled by the production } \\
\text { and expenditure approaches at current and } \\
\text { chained average } 2005 \text { prices, as well as annual } \\
\text { input-output tables, and the sequence of } \\
\text { accounts up to the financial account for the total } \\
\text { economy and by institutional sector. The } \\
\text { economic territory, production, and asset } \\
\text { boundaries are generally in accordance with } \\
\text { the } 1993 \text { SNA. Illegal activities are not explicitly } \\
\text { included in GDP, but these are not significant in } \\
\text { Korea. } \\
\text { Classification/sectorization. Economic } \\
\text { activities are classified according to the Korean } \\
\text { Standard Industrial Classification (KSIC), which } \\
\text { is consistent with International Standard } \\
\text { Industrial Classification (ISIC) Rev } 4 \text {. } \\
\text { Classifications of Individual Consumption by } \\
\text { Purpose (COICOP) and Classifications of the } \\
\text { Functions of Governments (COFOG) are used to } \\
\text { classify household consumption and the } \\
\text { functions of government, respectively. } \\
\text { Basis for recording. Market output and output } \\
\text { for own final use are valued at basic prices and } \\
\text { at equivalent market prices, respectively. } \\
\text { Intermediate consumption and final uses are } \\
\text { valued at purchasers' prices, including levied } \\
\text { sales/excise taxes and value added taxes, with } \\
\text { the deductible part excluded. Total exports and } \\
\text { imports are valued at free on board (f.o.b). } \\
\text { prices. Transactions are recorded on an accrual } \\
\text { basis. Transactions between establishments from } \\
\text { the same enterprise are recorded on a gross } \\
\text { basis. }\end{array}$ & $\begin{array}{l}\text { Source data. Data for the national } \\
\text { accounts are provided by KOSTAT, which } \\
\text { conducts quarterly and annual } \\
\text { establishment and enterprise surveys. The } \\
\text { surveys cover large proportions of the } \\
\text { total enterprise population. The BOK uses } \\
\text { HIES data collected monthly by } \\
\text { KOSTAT. Data for the government sector } \\
\text { and the BOP are obtained from other areas } \\
\text { in the BOK. Various monthly economic } \\
\text { activity surveys are also conducted by } \\
\text { KOSTAT. Source data are available on a } \\
\text { timely basis. } \\
\text { Assessment of source data. Appropriate } \\
\text { measures are taken to validate source data. } \\
\text { Statistical techniques. Both production } \\
\text { and expenditure estimates are compiled at } \\
\text { a sufficient level of detail. Chained } \\
\text { Laspeyres measures are used for volume } \\
\text { estimates of GDP. The Denton method is } \\
\text { used for seasonally adjusted estimates, but } \\
\text { not for original estimates. Depreciation } \\
\text { estimates are used instead of consumption } \\
\text { of fixed capital for all sectors except } \\
\text { general government. } \\
\text { Assessment and validation of } \\
\text { intermediate data and statistical } \\
\text { outputs. Discrepancies between } \\
\text { intermediate results and other independent } \\
\text { source data are measured and assessed } \\
\text { when compiling the national accounts. If } \\
\text { necessary, appropriate adjustments are } \\
\text { made to remove the discrepancies. } \\
\text { Revision studies. Analyses of time series } \\
\text { revisions are made only when updating the } \\
\text { reference year for volume estimates every } \\
\text { five years. }\end{array}$ & $\begin{array}{l}\text { Periodicity and timeliness. } \\
\text { Periodicity and timeliness of the } \\
\text { national accounts follow the } \\
\text { SDDS requirements. } \\
\text { Consistency. Consistent quarterly } \\
\text { and annual time series are } \\
\text { maintained from } 1970 \text {. In March } \\
2009 \text { chain volume measures were } \\
\text { introduced and a new reference } \\
\text { year (2005) was adopted. The } \\
\text { initial release covered the period } \\
\text { from } 2000 \text { forward, with the full } \\
\text { time series from } 1970 \text { being } \\
\text { released by the end of } 2009 \text {. } \\
\text { Consistency is maintained } \\
\text { between the quarterly and annual } \\
\text { national accounts series. The } \\
\text { national accounts statistics are } \\
\text { reconcilable with those from BOP } \\
\text { and GFS. } \\
\text { Revision policy and practice. } \\
\text { The revision cycle of the national } \\
\text { accounts is determined to align } \\
\text { with the availability of source data } \\
\text { and the timing of revisions to } \\
\text { related datasets. It is explained in } \\
\text { publications and press releases. } \\
\text { Revisions arising from the annual } \\
\text { seasonal reanalysis are discussed } \\
\text { in the quarterly national accounts } \\
\text { publication. Detailed analyses of } \\
\text { revisions for major aggregates are } \\
\text { published every five years at the } \\
\text { time of rebasing the volume } \\
\text { estimates. }\end{array}$ & $\begin{array}{l}\text { Data accessibility. Data are initially } \\
\text { disseminated via a press release and } \\
\text { on the BOK's website. Quarterly } \\
\text { data for value-added and } \\
\text { expenditure components of GDP are } \\
\text { provided in both original and } \\
\text { seasonally adjusted form. More } \\
\text { detailed statistics and unpublished } \\
\text { time series are provided through the } \\
\text { BOK's ECOS. Access to the ECOS } \\
\text { database requires the installation of } \\
\text { software that may cause computer } \\
\text { security concerns, particularly for } \\
\text { non-Korean users. An advance } \\
\text { release calendar for quarterly GDP } \\
\text { is also shown on the website. } \\
\text { National accounts statistics are } \\
\text { released simultaneously to all users. } \\
\text { Non-confidential information is } \\
\text { provided upon request. } \\
\text { Metadata accessibility. Metadata } \\
\text { are available on the BOK's website } \\
\text { and on the IMF's DSBB website. } \\
\text { Detailed sources and methods } \\
\text { publications are available for both } \\
\text { the quarterly and annual national } \\
\text { accounts, although the annual } \\
\text { version is only available in Korean. } \\
\text { See above for access problems. } \\
\text { Assistance to users. Contact } \\
\text { information is provided in } \\
\text { publications, and on the BOK } \\
\text { website. The BOK operates an } \\
\text { automated response service to } \\
\text { provide better service to users. User } \\
\text { requests are monitored daily and are } \\
\text { answered promptly. }\end{array}$ \\
\hline
\end{tabular}


Table 3b. Assessment of Data Quality-Dimensions 2 to 5-Consumer Price Index

\begin{tabular}{|c|c|c|c|}
\hline 2. Methodological soundness & 3. Accuracy and reliability & 4. Serviceability & 5. Accessibility \\
\hline $\begin{array}{l}\text { Concepts and definitions. The CPI } \\
\text { is compiled using concepts and } \\
\text { definitions that follow international } \\
\text { standards provided in the } 1993 \text { SNA } \\
\text { and the Consumer Price Index } \\
\text { Manual, } 2004 \text { (CPIM 2004). } \\
\text { Scope. The CPI covers all urban } \\
\text { households except for farming and } \\
\text { fishing households. The weights are } \\
\text { derived from the HIES and relate to } \\
\text { purchases of market goods and } \\
\text { services for consumption in } \\
\text { residential households. } \\
\text { Owner-occupied housing is not } \\
\text { included in the headline CPI, } \\
\text { although is included in a } \\
\text { supplementary index based on } \\
\text { imputed rentals. } \\
\text { Classification/sectorization. The } \\
\text { classification and sectorization used } \\
\text { are in broad conformity with } \\
\text { COICOP. } \\
\text { Basis for recording. Prices } \\
\text { collected for the CPI are } \\
\text { purchasers' prices of marketed } \\
\text { goods and services. Detailed } \\
\text { product specifications are used. The } \\
\text { weights are based on consumption } \\
\text { expenditure in purchasers' prices } \\
\text { which include trade and transport } \\
\text { margins and taxes on products. }\end{array}$ & $\begin{array}{l}\text { Source data. The items and weights for the CPI } \\
\text { are derived from the HIES which samples about } \\
9,000 \text { households. The outlet samples are } \\
\text { selected from the census and survey of wholesale } \\
\text { and retail trade. } 489 \text { items ( } 880 \text { specifications) } \\
\text { are collected from } 22,000 \text { outlets in } 38 \text { cities. } \\
\text { Assessment of source data. The Statistics } \\
\text { Quality Management Team of KOSTAT } \\
\text { evaluates all its surveys in accordance with the } \\
\text { Statistics Act. All prices are checked for } \\
\text { accuracy. } \\
\text { Statistical techniques. Temporarily missing } \\
\text { prices are generally imputed using the price } \\
\text { movements of similar products in the same } \\
\text { region, although out-of-season prices are simply } \\
\text { carried forward. Replacement items are selected } \\
\text { when a specific variety is unavailable. Quality } \\
\text { adjustments are made using a variety of } \\
\text { techniques consistent with international } \\
\text { standards. The Dutot formula is used for the } \\
\text { derivation of the elementary aggregates by city; } \\
\text { these are aggregated to national indices on the } \\
\text { basis of city expenditure shares. The Laspeyres } \\
\text { formula is used for higher level aggregations } \\
\text { with weight updates every five years-there are } \\
\text { plans to move to a three-yearly update cycle. } \\
\text { Assessment and validation of intermediate } \\
\text { data and statistical outputs. The CPI is } \\
\text { compared with relevant estimates from other } \\
\text { major price indices such as the PPI, export price } \\
\text { index, and import price index. } \\
\text { Revision studies. The CPI is final when first } \\
\text { released. Following the five-yearly rebase, the } \\
\text { effect of substitution bias on the index is } \\
\text { evaluated and revision studies are undertaken. }\end{array}$ & $\begin{array}{l}\text { Periodicity and timeliness. } \\
\text { The CPI is published } \\
\text { monthly and is released on } \\
\text { the first business day of the } \\
\text { following month. } \\
\text { Consistency. Upper-level } \\
\text { indices are compiled by } \\
\text { aggregating lower-level } \\
\text { indices and are hence } \\
\text { internally consistent. } \\
\text { Consistent monthly series } \\
\text { are available from } 1965 \text {. } \\
\text { Revision policy and } \\
\text { practice. The CPI is final } \\
\text { when first released. The CPI } \\
\text { items and weights are } \\
\text { updated every five years } \\
\text { (with the year ending in } 0 \\
\text { or 5). The next rebase will } \\
\text { relate to } 2010 \text { data. }\end{array}$ & $\begin{array}{l}\text { Data accessibility. Data are } \\
\text { disseminated in a monthly news } \\
\text { release which contains a short } \\
\text { analysis, time series, and charts. } \\
\text { More tables are subsequently } \\
\text { released in monthly and annual } \\
\text { reports. KOSTAT's website } \\
\text { presents more detailed and longer } \\
\text { time series. The CPI is released } \\
\text { simultaneously to all users. Data } \\
\text { are provided through the KOSIS of } \\
\text { KOSTAT. However, access to the } \\
\text { KOSIS requires the installation of } \\
\text { software that may cause security } \\
\text { concerns, particularly for non- } \\
\text { Korean users. } \\
\text { Metadata accessibility. Metadata } \\
\text { are provided in the news release, } \\
\text { publications and on KOSTAT's } \\
\text { website. See above for access } \\
\text { problem. } \\
\text { Assistance to users. The news } \\
\text { release and publication contain } \\
\text { contact names and telephone and } \\
\text { fax numbers. The website contains } \\
\text { "Frequently Asked Questions." } \\
\text { There are catalogs of publications } \\
\text { and the website contains a } \\
\text { Statistical Shopping Mall. }\end{array}$ \\
\hline
\end{tabular}




\begin{tabular}{|c|c|c|c|}
\hline 2. Methodological soundness & 3. Accuracy and reliability & 4. Serviceability & 5. Accessibility \\
\hline $\begin{array}{l}\text { Concepts and definitions. Concepts } \\
\text { and definitions used for the recording } \\
\text { and valuation of product prices and } \\
\text { weights are consistent with the } \\
\text { Producer Price Index Manual, } 2004 \\
\text { (PPIM 2004). Indices are published } \\
\text { for detailed industry groups and } \\
\text { commodities, and by stage of } \\
\text { processing. } \\
\text { Scope. The index relates to domestic } \\
\text { transactions at market prices for the } \\
\text { output of the agriculture, mining, } \\
\text { manufacturing, energy and selected } \\
\text { service industries including transport, } \\
\text { telecommunications, finance, real } \\
\text { estate, advertising, and technical } \\
\text { services. } \\
\text { Classification/sectorization. } \\
\text { The PPI uses the } 1993 \text { SNA concepts } \\
\text { of institutional units and transactions. } \\
\text { The Korean commodity classification } \\
\text { used for the PPI does not conform to } \\
\text { any international standard. An } \\
\text { internationally based classification is } \\
\text { under development and will be used } \\
\text { for the } 2010 \text { index rebase. } \\
\text { Basis for recording. The PPI } \\
\text { weights and prices conform to the } \\
\text { PPIM } 2004 \text { valuation rules. Pricing is } \\
\text { based on basic prices excluding trade } \\
\text { and transport margins and product } \\
\text { taxes. The product specifications are } \\
\text { sufficient to measure "pure price } \\
\text { change." }\end{array}$ & $\begin{array}{l}\text { Source data. The } 2005 \text { mining, manufacturing, and } \\
\text { agriculture censuses, and the } 2005 \text { input-output tables } \\
\text { (for the selected service industries), are the major } \\
\text { sources for weights, and were used as the sampling } \\
\text { frame for selecting commodities and establishments for } \\
\text { the price survey, based on cutoff sampling. Prices are } \\
\text { collected from } 6,100 \text { establishments for } 801 \text { goods and } \\
83 \text { services. } \\
\text { Assessment of source data. Response rates to the } \\
\text { price survey are nearly } 100 \text { percent. Large price } \\
\text { changes are investigated, and price collectors visit the } \\
\text { establishments several times a year to verify the } \\
\text { appropriateness of the specifications and accuracy of } \\
\text { the reported prices. } \\
\text { Statistical techniques. Temporarily and seasonal } \\
\text { missing prices are imputed by simply carrying forward } \\
\text { the last reported price. For permanently missing prices, } \\
\text { replacement specifications are selected and quality } \\
\text { adjustment made as necessary by reference to } \\
\text { production values or linking with overlapping prices. } \\
\text { Elementary aggregate indices are calculated as the } \\
\text { simple arithmetic mean of price relatives (Carli } \\
\text { formula). This is against international } \\
\text { recommendations and introduces an upward bias. The } \\
\text { Laspeyres (long-term price relatives) formula is used } \\
\text { for progressive aggregation to higher levels in the } \\
\text { index structure. } \\
\text { Assessment and validation of intermediate data and } \\
\text { statistical outputs. PPI series are regularly compared } \\
\text { with corresponding CPI, import price index, export } \\
\text { price component series, and private sector measures. } \\
\text { After the five-yearly rebase, a study is conducted to } \\
\text { identify the effect of weight shifts, new and deleted } \\
\text { items, and the extent of substitution bias. }\end{array}$ & $\begin{array}{l}\text { Periodicity and timeliness. } \\
\text { The PPI is published on a } \\
\text { monthly basis and is generally } \\
\text { released around the tenth day } \\
\text { after the reference month, } \\
\text { meeting SDDS requirements. } \\
\text { Consistency. The PPI is } \\
\text { internally consistent and is } \\
\text { invariant to the two } \\
\text { classification typologies used. } \\
\text { Consistent aggregate series are } \\
\text { available back to the last } \\
\text { revision in 2005; prior to that, } \\
\text { there is a consistent historical } \\
\text { series for goods industries } \\
\text { prior to the introduction of } \\
\text { services in 1995. } \\
\text { Revision policy and practice } \\
\text { There are no monthly } \\
\text { revisions. Index items and } \\
\text { weights are updated on a } \\
\text { five-yearly basis, and a } \\
\text { detailed analysis of the results } \\
\text { of the revision is published. }\end{array}$ & $\begin{array}{l}\text { Data accessibility. Summary PPI } \\
\text { are released through a press } \\
\text { release, and at the five-digit level } \\
\text { and more aggregated levels of the } \\
\text { KSIC on the BOK's website. The } \\
\text { release date is announced a week } \\
\text { in advance and data are made } \\
\text { available to all users } \\
\text { simultaneously. The access to the } \\
\text { data posted in the BOK's online } \\
\text { database (ECOS) requires the } \\
\text { installation of software that may } \\
\text { create computer security concerns } \\
\text { particularly for non-Korean users. } \\
\text { Metadata accessibility. The } \\
\text { BOK publishes a Guide to } \\
\text { Economic Statistics which covers } \\
\text { the PPI methodology. A more } \\
\text { detailed description of the } \\
\text { methodology is contained in the } \\
\text { Report on the } 2005 \text { Revision on } \\
\text { the BOK's website. See above for } \\
\text { access problem. } \\
\text { Assistance to users. The BOK } \\
\text { has a call desk handled by an } \\
\text { economist to assist users. The } \\
\text { BOK's website contains contact } \\
\text { details and a list of publications. }\end{array}$ \\
\hline
\end{tabular}


Table 3d. Assessment of Data Quality-Dimensions 2 to 5-Government Finance Statistics

\begin{tabular}{|c|c|c|c|}
\hline 2. Methodological soundness & 3. Accuracy and reliability & 4. Serviceability & 5. Accessibility \\
\hline $\begin{array}{l}\text { Concepts and definitions. Korean } \\
\text { GFS generally follows the } \\
\text { recommendations of the } \\
\text { GFSM } 1986 \text {. However, the reform } \\
\text { process that will make it possible to } \\
\text { move to the GFSM } 2001 \text { is well } \\
\text { advanced, and will lead to the } \\
\text { publication of a new set of accounts } \\
\text { in } 2012 . \text { Most local government } \\
\text { agencies have already introduced } \\
\text { accrual accounting and double } \\
\text { bookkeeping, but cash data remain } \\
\text { available. } \\
\text { Scope. The sectoral scope is } \\
\text { defined on a functional basis in } \\
\text { accordance with the } G F S M 1986 . \\
\text { The accounts of central, local, and } \\
\text { general government are prepared. } \\
\text { Classification/sectorization } \\
\text { follows the GFSM } 1986 \text {. Local } \\
\text { education is included since } 2005 \text {. } \\
\text { Basis for recording. Transactions } \\
\text { are recorded in accordance with the } \\
G F S M 1986 \text { when cash is received } \\
\text { or paid. Equally, debt is valued at } \\
\text { face value. As of } 2009 \text {, the GFS are } \\
\text { exclusively compiled on a cash } \\
\text { basis. Transactions are shown on a } \\
\text { gross basis. Tax refunds are } \\
\text { correctly recorded as negative tax } \\
\text { revenue. Intra-government stocks } \\
\text { and flows are consolidated. }\end{array}$ & $\begin{array}{l}\text { Source data. Source data have } \\
\text { sufficient detail for the compilation } \\
\text { of GFS. Automated systems } \\
\text { convert accounting data of } \\
\text { individual agencies to GFS } \\
\text { categories. } \\
\text { Assessment of source data. } \\
\text { Detailed source data are fully } \\
\text { reconcilable with the GFS } \\
\text { definitions and classifications. They } \\
\text { are timely and allow consolidation. } \\
\text { The compilation systems perform } \\
\text { automated cross-checks. } \\
\text { Statistical techniques. Data are } \\
\text { based on complete information. The } \\
\text { classification and aggregation } \\
\text { algorithms are part of the } \\
\text { automated compilation systems, so } \\
\text { application of statistical techniques } \\
\text { is not necessary. } \\
\text { Assessment and validation of } \\
\text { intermediate data and statistical } \\
\text { outputs. Intermediate data are each } \\
\text { month compared with other } \\
\text { sources, such as information } \\
\text { available at the BOK or in assigned } \\
\text { regional banks, tax receipts, and the } \\
\text { progress of major projects. Also } \\
\text { comparisons are made with data for } \\
\text { the previous year. } \\
\text { Revision studies. Minor revisions } \\
\text { may occur. Due to the } \\
\text { administrative nature of the data } \\
\text { they are not subject to particular } \\
\text { studies. }\end{array}$ & $\begin{array}{l}\text { Periodicity and timeliness. } \\
\text { Detailed data for the central } \\
\text { government are disseminated on a } \\
\text { monthly basis, and data for the } \\
\text { general government on an annual } \\
\text { basis. Central government debt } \\
\text { data are disseminated quarterly. } \\
\text { Timeliness is generally in } \\
\text { accordance with the SDDS, } \\
\text { except for the general government } \\
\text { operations (disseminated after } \\
\text { about } 13 \text { months versus the } \\
\text { mandatory two quarters). } \\
\text { Consistency. Consistent time } \\
\text { series are available, as any } \\
\text { changes are reconstructed as far } \\
\text { back as possible. There are some } \\
\text { differences in scope between the } \\
\text { flow tables and the government } \\
\text { debt table. GFS are in principle } \\
\text { reconcilable with other } \\
\text { macroeconomic statistics as they } \\
\text { share the budget administrative } \\
\text { records as the main source for } \\
\text { government operations. } \\
\text { Revision policy and practice. } \\
\text { Preliminary data are clearly } \\
\text { identified. They are revised } \\
\text { according to a fixed schedule. No } \\
\text { schedule for major revisions } \\
\text { exists. Revisions and unusual } \\
\text { trends are explained in the } \\
\text { publications. }\end{array}$ & $\begin{array}{l}\text { Data accessibility. The MOSF } \\
\text { publishes general government } \\
\text { accounts on its website. In addition } \\
\text { the MOSF publishes central } \\
\text { government data, while the MOPAS } \\
\text { disseminates statistics for local } \\
\text { government on an accrual basis. The } \\
\text { MEST does not disseminate GFS for } \\
\text { local education. } \\
\text { Accompanying analysis and charts in } \\
\text { press releases facilitate users' } \\
\text { interpretation. A bridge between GFS } \\
\text { and central government budget } \\
\text { documents is also made available. } \\
\text { Release dates are not preannounced, } \\
\text { but follow a traditional and well- } \\
\text { understood schedule. There is no } \\
\text { prerelease access to publications. } \\
\text { More detailed data are available on } \\
\text { request. } \\
\text { Metadata accessibility. Central } \\
\text { government metadata are provided in } \\
\text { the Government Finance Statistics of } \\
\text { Korea and the Government Debt } \\
\text { Management Plan. Key concepts } \\
\text { used in the budget document are } \\
\text { presented in the publication Budget } \\
\text { Overview. The DSBB provides } \\
\text { metadata for general government. } \\
\text { Some metadata are provided in the } \\
\text { Government Finance Statistics of } \\
\text { Korea. } \\
\text { Assistance to users. Contact points } \\
\text { are publicized and the timeliness of } \\
\text { response on questions is monitored. } \\
\text { The MOSF website includes a short } \\
\text { catalog of publications. }\end{array}$ \\
\hline
\end{tabular}




\section{Methodological soundness \\ Concepts and definitions. Monetary}

statistics broadly follow the MFSM, The monetary authorities account (MAA) is the consolidation of the BOK and the Foreign Exchange Stabilization Fund (FESF) accounts. The MAA does not identify the monetary base, although reserve money is presented in a separate table.

Scope. Coverage of the depository corporations survey (DCS) is complete, as it covers the BOK (as well as the FESF), all commercial and specialized banks, and all nonbank depository corporations.

\section{Classification/sectorization.}

Classification and sectorization of financial instruments largely follow the methodology of the MFSM, except the grouping of instruments for monetary aggregates.

Basis for recording. Monetary statistics are produced on an accrual basis. The BOK values its financial assets and liabilities at book value (rather than at market value) and revalues foreign currency instruments twice yearly (rather than monthly)

\section{Accuracy and reliability}

Source data. Data on the BOK and the

FESF are based on their balance sheets. All other depository corporations (ODCs) report their balance-sheet data to the $\mathrm{BOK}$ on a monthly basis. The structures of the balance-sheet report forms require the provision of highly detailed data for compiling monetary statistics.

\section{Assessment of source data. Computerized} procedures in the data collection system (DACOS) operated through the BOK's website facilitate monitoring of the accuracy of data reported by individual ODCs.

Statistical techniques. The potential for processing errors is minimized by using electronic reporting and processing procedures. The monetary and liquidity aggregates are seasonally adjusted using customized software.

\section{Assessment and validation of}

\section{and statistical outputs.}

Reported data by ODCs are cross-checked with the balance sheets reported to the Financial Supervisory Service. Securities holdings and classifications are cross-checked with the Korea Securities Depository database and survey data from securities finance companies.

Revision studies. Where relevant, revisions are studied.

\section{Serviceability \\ Periodicity and timeliness.}

Monetary statistics are compiled on a monthly basis, and

disseminated within six weeks after the end of the month, rather than within the SDDS timeliness requirement of one month. Korea is availing itself of a flexibility option on the timeliness of the DCS.

Consistency. Consistent time series are available for over eight years. The consistency of the BOK's and the ODCs records is not cross-checked regularly. The disseminated data do not allow for cross-checking of positions between the BOK and ODCs and among ODCs, as these positions are not separately identified.

Monetary data are consistent with the BOP and the International Investment Position (IIP), as the main source for these sets of data on depository corporations is the monetary statistics. Bonds issued by the FESF are recorded as a foreign liability in the MAA, and also included in the central government external debt.

\section{Revision policy and practice}

DCS data are final when first released. The data are revised only when errors are detected and methodological changes applied. Revised data are clearly

identified.

\section{Accessibility}

Data accessibility. Data are

disseminated through press releases, the BOK's ECOS on its website, and through statistical publications. The BOK publishes, and complies with, an advance release calendar for monetary data. Data are first disseminated via a press release and then posted on the BOK's website, ensuring simultaneous access by all users, and also published in the BOK's statistical publications (also posted on the website). However, access to the ECOS database requires the installation of software that may cause computer security concerns, particularly for non-Korean users.

Metadata accessibility. Korea has posted its monetary metadata on the IMF's DSBB since March 1998. The Explanation of Monetary and Financial Statistics (2008) contains detailed metadata on monetary statistics. See above regarding access problems.

Assistance to users. Information on contact points for monetary statistics is available on the DSBB, through ECOS, and in publications. Users' requests and comments are channeled through the BOK's website. 
Table 3f. Assessment of Data Quality-Dimensions 2 to 5-Balance of Payments Statistics

\begin{tabular}{|c|c|c|c|}
\hline 2. Methodological soundness & 3. Accuracy and reliability & 4. Serviceability & 5. Accessibility \\
\hline $\begin{array}{l}\text { Concepts and definitions have been } \\
\text { broadly in accordance with the } \\
B P M 5 \text { since } 1998 \text {. In March } 2003 \text {, } \\
\text { the BOK released its first annual IIP } \\
\text { and in } 2007 \text { switched from annual to } \\
\text { quarterly reporting of IIP. The } \\
\text { authorities plan to implement the } \\
B P M 6 \text { framework in } 2010 \text { and } \\
\text { disseminate data using this } \\
\text { framework in } 2012 \text {. } \\
\text { Scope is broadly consistent with } \\
\text { international guidelines. However, } \\
\text { only partial data are compiled on } \\
\text { foreign currency transactions of } \\
\text { enterprises through accounts held } \\
\text { abroad and on reinvested earnings. } \\
\text { Classification/sectorization is } \\
\text { mostly in line with the } B P M 5 \\
\text { guidelines. Nevertheless, there are } \\
\text { some departures that arise mainly in } \\
\text { the sectoral classification and the } \\
\text { classification of trade credits and } \\
\text { short-term loans with affiliated } \\
\text { entities (they are recorded under } \\
\text { other investment instead of direct } \\
\text { investment). } \\
\text { Basis for recording, valuation, and } \\
\text { grossing/netting procedures are } \\
\text { generally in line with the } B P M 5 \\
\text { framework. However, income } \\
\text { transactions are recorded on a } \\
\text { payment basis. }\end{array}$ & $\begin{array}{l}\text { Source data are broadly sufficient to } \\
\text { compile BOP. Main sources include } \\
\text { (i) customs data, (ii) the BOK's foreign } \\
\text { exchange information system (FEIS), } \\
\text { (iii) administrative data reported by } \\
\text { other government entities, (iv) surveys, } \\
\text { and (v) direct reporting by financial and } \\
\text { nonfinancial institutions. These data are } \\
\text { supplemented with information from } \\
\text { foreign agencies and international } \\
\text { financial institutions. There is no } \\
\text { systemic mechanism to collect noncash } \\
\text { operations, although these are } \\
\text { insignificant in Korea. Source data are } \\
\text { timely. } \\
\text { Assessment of source data. Source } \\
\text { data are routinely assessed. } \\
\text { Statistical techniques and procedures } \\
\text { are used by the BOK to adjust foreign } \\
\text { trade transactions, to overcome partial } \\
\text { coverage of some services and portfolio } \\
\text { investment transactions, and to improve } \\
\text { the classification of some items. } \\
\text { Assessment and validation of } \\
\text { intermediate data and statistical } \\
\text { output. Statistical discrepancies are } \\
\text { assessed, and data validated with } \\
\text { available administrative data and other } \\
\text { datasets. } \\
\text { Revision studies. Studies and analysis } \\
\text { of data revisions are performed, and } \\
\text { measures are taken to incorporate } \\
\text { findings of revision studies. }\end{array}$ & $\begin{array}{l}\text { Periodicity and timeliness of } \\
\text { BOP and IIP statistics exceed } \\
\text { SDDS requirements. } \\
\text { Consistency. BOP data are } \\
\text { broadly consistent internally } \\
\text { and over time, and with other } \\
\text { datasets. } \\
\text { Revision policy and practice. } \\
\text { Preliminary data are revised } \\
\text { and finalized during the second } \\
\text { half of the following year. The } \\
\text { preliminary and revised data } \\
\text { are clearly identified. } \\
\text { Generally, revised data are } \\
\text { published in the following } \\
\text { publication. Although revisions } \\
\text { do not follow a schedule, there } \\
\text { is a well-established practice of } \\
\text { revisions known by users. } \\
\text { Explanations of any differences } \\
\text { are presented in the press } \\
\text { release. }\end{array}$ & $\begin{array}{l}\text { Data accessibility. Data are } \\
\text { broadly disseminated in accordance } \\
\text { with the BPM5 standard } \\
\text { components. Data are made } \\
\text { available to all users at the same } \\
\text { time on the BOK's website and } \\
\text { released on a preannounced } \\
\text { schedule. The access to the data } \\
\text { posted in the BOK's online } \\
\text { database (ECOS) requires the } \\
\text { installation of software that may } \\
\text { create computer security concerns } \\
\text { particularly for non-Korean users. } \\
\text { Unpublished (but non-confidential) } \\
\text { subaggregates are made available } \\
\text { upon request. } \\
\text { Metadata accessibility. Concepts, } \\
\text { methodology, and data sources for } \\
\text { BOP compilation are available on } \\
\text { the BOK's website, as well as the } \\
\text { IMF's DSBB and other BOK } \\
\text { publications. } \\
\text { Assistance to users is adequate. } \\
\text { Publications available on the } \\
\text { BOK's website provide contact } \\
\text { points. Contact points for BOP data } \\
\text { are also provided on the Fund's } \\
\text { DSBB. Catalogs of publications, } \\
\text { documents, and other services are } \\
\text { widely available in the ECOS. }\end{array}$ \\
\hline
\end{tabular}




\section{STAFF's RECOMMENDATIONS}

14. Based on the review of Korea's statistical practices, discussions with the data-producing agencies, and responses from data users (see Appendix III of the Detailed Assessments volume), the following recommendations are offered. They are designed to increase further Korea's adherence to internationally accepted statistical practices and would, in the mission's view, enhance the analytical usefulness of Korea's statistics. Some additional suggestions are included in the accompanying Detailed Assessments volume.

\section{Cross-cutting recommendations}

- Expedite plans to remove the "Active X" problem affecting the BOK and KOSTAT by which international and other users with firewall protection have difficulty, or are unable, to download software necessary for accessing the data and metadata.

- Maintain coordination across agencies to ensure data consistency during the migration process towards the new methodologies.

\section{National accounts}

- Use the Denton method to adjust quarterly original estimates to agree with annual benchmark estimates.

- $\quad$ Replace the existing estimates of depreciation with estimates for consumption of fixed capital for all sectors other than general government. The estimates for consumption of fixed capital should be derived using the Perpetual Inventory Method (PIM) methodology.

- $\quad$ Periodically undertake an analysis of revisions to movements in quarterly GDP (and its components) in current price and volume terms between preliminary and final estimates from 1999 forward (the first year that seasonally adjusted estimates were published).

- Investigate the feasibility of developing estimates for the non-observed economy using employment estimates from the Labor Force Survey (conducted by KOSTAT) and employment estimates from other data sources used to compile the national accounts.

- $\quad$ Aim to remove the statistical discrepancy between the production and expenditure measures of GDP, on an annual basis, by compiling balanced annual supply-and-use tables.

\section{Consumer price index}

- $\quad$ In the context of the 2010 CPI rebase, consult widely with users (especially the BOK) to determine the current principal use of the CPI (e.g., in the measurement of consumption or inflation), define the most appropriate headline measure (e.g., including or excluding owner-occupied dwellings), decide on the preferred 
treatment of owner-occupied dwellings (imputed rentals or net acquisitions) and define core or underlying inflation. Consider whether to give greater prominence to a broader measure of price changes than the present "all items" index that excludes owner-occupied dwellings.

- $\quad$ Review the methodology for estimating missing seasonal product prices, with the aim of removing the bias associated with using the simple carry-forward method.

- As part of the consultations planned for the prospective rebasing program consult on the proposal to change from a five-yearly to a three-yearly rebase cycle by reference to a detailed analysis of the extent of substitution bias associated with the use of the Laspeyres formula. Assess the relative improvement obtained by adopting a three-year cycle compared with that from an annual cycle.

- $\quad$ Assess the feasibility of including farming and fishing households within the scope of the CPI either by extending the scope of the HIES or incorporating data on expenditure patterns from the Farming and Fishing Household Economic Surveys during the weight calculation exercise.

\section{Producer price index}

- Implement a Korean Central Product Classification, based on the Central Product Classification, for the 2010 PPI rebase in 2013.

- $\quad$ Introduce the use of more sophisticated techniques for imputing temporarily missing prices for both regular and seasonal products, as described in the PPIM 2004.

- $\quad$ Continue the compilation and study of the Korean supplementary PPI using the geometric mean formula for the computation of elementary aggregate indices. Implement with the 2010 rebase. To the extent that the component products within an elementary aggregate are heterogeneous, with a resultant disparity of price levels, cluster the prices within such elementary aggregates within narrow price bands, and ensure the units of measurement are comparable.

- $\quad$ Continue the compilation and study of annual chain Laspeyres PPIs, and implement with the next index rebase to counter the impact of substitution bias.

- In metadata documentation, explicitly identify areas where there are departures from international standards in the Korean PPI.

\section{Government finance statistics}

- $\quad$ Continue the development of a national (electronic) publication dedicated to the dissemination of data and metadata for general government and its subsectors in Korean and English.

- $\quad$ Strive to make a detailed sources and methods publication of the Korean GFS compilation available to users in Korean and English. 
- $\quad$ Study the possibilities to publish the general government operations data within the timeliness prescribed by the SDDS, and thus withdraw the SDDS flexibility option.

- Footnote in all publications of government debt that, in contrast to the functional definition of government in the operations accounts, the central government debt data also include bonds issued by the FESF. Furthermore, involve the BOK and KOSTAT in the discussions on how to make the GFSM 2001 definition of government operational in Korea. Consider classifying the FESF into the accounts of the central government at the time of the GFSM 2001 migration, in line with the precepts of that manual.

\section{Monetary statistics}

- In the future, along with the implementation of the GFSM 2001 methodology, consider recording all FESF flows and stocks in the central government accounts. Ensure consistent treatment of the FESF accounts in the monetary statistics, BOP, IIP, and GFS at all stages.

- For monetary statistics purposes value all marketable financial instruments in the BOK balance sheet, including monetary gold, on the basis of market prices, and revalue assets and liabilities denominated in foreign currencies at the end of every month.

- In compiling the ODCs, do not include net claims on the BOK in the consolidation adjustment, but present claims on, and liabilities to, the BOK on the assets and liabilities side, respectively.

- Take necessary actions to be able to disseminate the DCS within one month after the end of the reference month, in order to withdraw the SDDS flexibility option.

- Introduce regular cross-checking procedures of positions between the BOK and the ODCs, as well as positions among ODCs.

\section{Balance of payments statistics}

- $\quad$ Expand the transactions coverage by including all transactions on reinvested earnings and foreign-currency transactions of enterprises through accounts held abroad.

- Improve the classification of direct investment transactions by reclassifying data on trade credits and short-term loans of affiliated enterprises.

- Align the basis of recording of income transactions to that recommended by the international standards. 


\section{Appendix Table I. Practices Compared to the SDDS Coverage, Periodicity, and Timeliness of Data}

\begin{tabular}{|c|c|c|c|c|c|c|}
\hline \multirow{2}{*}{$\begin{array}{c}\text { SDDS } \\
\text { Data } \\
\text { Category }\end{array}$} & \multirow{2}{*}{$\begin{array}{c}\text { Coverage } \\
\text { (meets SDDS } \\
\text { requirement) }\end{array}$} & \multicolumn{2}{|c|}{ Periodicity } & \multicolumn{2}{|c|}{ Timeliness } & \multirow[t]{2}{*}{ Comments } \\
\hline & & SDDS & Korea & SDDS & Korea & \\
\hline \multicolumn{7}{|l|}{ Real Sector } \\
\hline National accounts & Yes & Q & Q & Q & $\begin{array}{l}2 \text { months } \\
\text { for Q1-Q3, } \\
\text { and one } \\
\text { quarter for } \\
\text { Q4 data }\end{array}$ & \\
\hline $\begin{array}{l}\text { Production } \\
\text { index/indices }\end{array}$ & Yes & $\mathrm{M}$ & $\mathrm{M}$ & $\begin{array}{c}6 \mathrm{~W} \\
(1 \mathrm{M} \\
\text { encouraged })\end{array}$ & $\mathrm{M}$ & \\
\hline $\begin{array}{l}\text { Forward-looking } \\
\text { Indicators }\end{array}$ & $\begin{array}{c}\text { (encouraged } \\
\text { data category) }\end{array}$ & $M$ or $Q$ & $\mathrm{M}$ & $M$ or $Q$ & $\mathrm{M}$ & \\
\hline Employment & Yes & Q & $\mathrm{M}$ & Q & $\mathrm{M}$ & $\begin{array}{l}\text { Periodicity and } \\
\text { timeliness exceed } \\
\text { SDDS } \\
\text { requirements }\end{array}$ \\
\hline Unemployment & Yes & Q & $\mathrm{M}$ & Q & $\mathrm{M}$ & As above \\
\hline Wages/earnings & Yes & $\mathrm{Q}$ & $\mathrm{M}$ & $\mathrm{Q}$ & $\mathrm{M}$ & As above \\
\hline $\begin{array}{l}\text { Consumer price } \\
\text { index }\end{array}$ & Yes & $\mathrm{M}$ & $\mathrm{M}$ & $\mathrm{M}$ & $1-2 \mathrm{D}$ & $\begin{array}{l}\text { Timeliness } \\
\text { exceeds SDDS } \\
\text { requirements }\end{array}$ \\
\hline $\begin{array}{l}\text { Producer price } \\
\text { index }\end{array}$ & Yes & $\mathrm{M}$ & $\mathrm{M}$ & $\mathrm{M}$ & $10 \mathrm{D}$ & As above \\
\hline \multicolumn{7}{|l|}{ Fiscal Sector } \\
\hline $\begin{array}{l}\text { General government } \\
\text { operations }\end{array}$ & Yes & $\mathrm{A}$ & $\mathrm{A}$ & $2 Q$ & $5 \mathrm{Q}$ & $\begin{array}{c}\text { Flexibility option } \\
\text { for timeliness }\end{array}$ \\
\hline $\begin{array}{l}\text { Central government } \\
\text { operations }\end{array}$ & Yes & $\mathrm{M}$ & $\mathrm{M}$ & $\mathrm{M}$ & $\mathrm{M}$ & \\
\hline $\begin{array}{l}\text { Central government } \\
\text { debt }\end{array}$ & Yes & Q & Q & Q & Q & \\
\hline \multicolumn{7}{|l|}{ Financial Sector } \\
\hline $\begin{array}{l}\text { Depository } \\
\text { Corporations survey }\end{array}$ & Yes & $\mathrm{M}$ & $\mathrm{M}$ & $\mathrm{M}$ & $6 \mathrm{~W}$ & $\begin{array}{c}\text { Flexibility option } \\
\text { for timeliness }\end{array}$ \\
\hline Central bank survey & Yes & $\begin{array}{c}\mathrm{M} \\
(1 \mathrm{~W} \text { re- } \\
\text { commend } \\
\text { ed) }\end{array}$ & $\mathrm{M}$ & $\begin{array}{c}2 \mathrm{~W} \\
(1 \mathrm{~W} \\
\text { encouraged })\end{array}$ & $2 \mathrm{~W}$ & \\
\hline Interest rates & & $\mathrm{D}$ & $\mathrm{D}$ & $\ldots$ & $\mathrm{D}$ & \\
\hline $\begin{array}{l}\text { Stock market: share } \\
\text { price index }\end{array}$ & Yes & $\mathrm{D}$ & $\mathrm{D}$ & $\ldots$ & $\mathrm{D}$ & \\
\hline
\end{tabular}




\begin{tabular}{|c|c|c|c|c|c|c|}
\hline \multirow{2}{*}{$\begin{array}{c}\text { SDDS } \\
\text { Data } \\
\text { Category }\end{array}$} & \multirow{2}{*}{$\begin{array}{c}\text { Coverage } \\
\text { (meets SDDS } \\
\text { requirement) }\end{array}$} & \multicolumn{2}{|c|}{ Periodicity } & \multicolumn{2}{|c|}{ Timeliness } & \multirow[t]{2}{*}{ Comments } \\
\hline & & SDDS & Korea & SDDS & Korea & \\
\hline \multicolumn{7}{|l|}{ External Sector } \\
\hline $\begin{array}{c}\text { Balance of } \\
\text { payments }\end{array}$ & Yes & Q & $\mathrm{M}$ & Q & $\mathrm{M}$ & $\begin{array}{c}\text { Periodicity and } \\
\text { timeliness exceed } \\
\text { SDDS } \\
\text { requirements } \\
\end{array}$ \\
\hline $\begin{array}{l}\text { Official reserve } \\
\text { assets } \\
\text { Reserves template }\end{array}$ & Yes & $\begin{array}{c}\mathrm{M} \\
\text { (W re- } \\
\text { commend } \\
\text { ed) } \\
\mathrm{M}\end{array}$ & $\mathrm{M}$ & $\mathrm{W}$ & $\mathrm{W}$ & \\
\hline Merchandise trade & Yes & $\mathrm{M}$ & $\mathrm{M}$ & $\begin{array}{c}8 \mathrm{~W} \\
(4-6 \mathrm{~W} \\
\text { encouraged })\end{array}$ & $3 \mathrm{D}$ & $\begin{array}{l}\text { Timeliness } \\
\text { exceeds SDDS } \\
\text { requirements }\end{array}$ \\
\hline $\begin{array}{l}\text { International } \\
\text { investment } \\
\text { position }\end{array}$ & Yes & $\begin{array}{c}\text { A } \\
\text { (Q re- } \\
\text { commend } \\
\text { ed) }\end{array}$ & Q & $\begin{array}{c}3 \mathrm{Q} \\
(1 Q \\
\text { encouraged })\end{array}$ & Q & \\
\hline External debt & Yes & $Q$ & $Q$ & $Q$ & $Q$ & \\
\hline Exchange rates & Yes & $\mathrm{D}$ & $\mathrm{D}$ & $\ldots$ & $\mathrm{D}$ & \\
\hline $\begin{array}{l}\text { Addendum: } \\
\text { Population }\end{array}$ & Yes & $\mathrm{A}$ & $\mathrm{A}$ & $\ldots$ & $\mathrm{A}$ & \\
\hline
\end{tabular}

Note: Periodicity and timeliness: (D) daily or days; (W) weekly or with a lag of no more than one week from the reference data or the closing of the reference week; (M) monthly or with a lag of no more than one month; (Q) quarterly or with a lag of no more than one quarter; (A) annually; and (...) not applicable.

Italics indicate encouraged categories. 


\section{INTERNATIONAL MONETARY FUND}

REPUBLIC OF KOREA

\section{Report on the Observance of Standards and Codes (ROSC)—Data Module Volume II}

\section{Response by the Authorities}

July 8, 2010

\section{Contents}

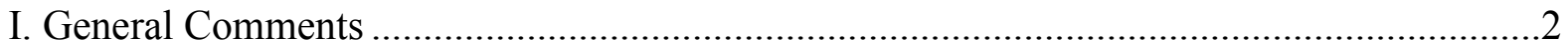

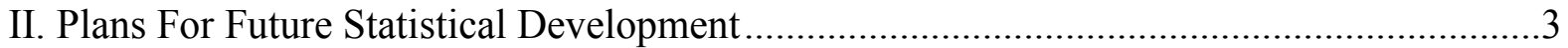

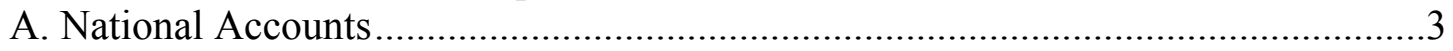

B. Consumer Price Index .............................................................................

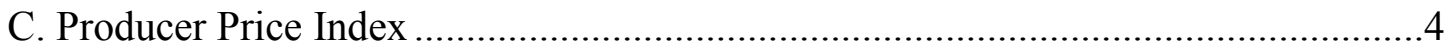

D. Government Finance Statistics.......................................................................... 5

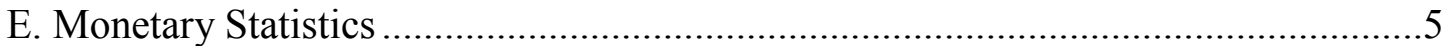

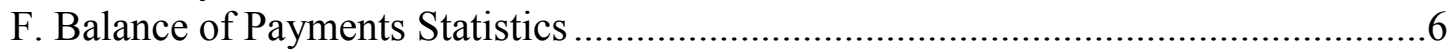




\section{General Comments}

\section{Bank of Korea}

The ROSC mission of the International Monetary Fund (IMF) has proved to be very helpful in reviewing and improving the quality of statistics compiled and disseminated by the Bank of Korea (BOK).

The BOK concurs with most of the concluding recommendations made by the IMF. Some of the recommendations have already been implemented and have contributed to improving our statistical framework, and others will be followed up in the future development of our statistical systems.

Regarding Active-X, as mentioned in the report, the BOK plans to resolve the problem by 2012, when state-of-the-art browser-free access will be introduced. The BOK will make full use of all available systems of cooperation among the related agencies to maintain data consistency during the migration process towards the new methodology such as BPM6 or SNA 2008.

We are also pleased to inform you that we approve the posting the entire ROSC-Data Module document to the IMF's website.

Detailed responses concerning each set of statistics are set out below.

\section{Statistics Korea}

It was useful for the Statistics Korea (KOSTAT) to cooperate with the IMF's mission team to review the quality of the CPI in compliance with the international standards. While preparing the 2010 rebase of the CPI, the KOSTAT implements your recommendations by establishing the action plans as follows.

\section{Ministry of Finance and Economy}

During the IMF Mission's visit to Korea, we had the pleasure to be given the opportunity to review the quality of our government finance statistics by considering compliance with international standards.

The MOSF will continue its efforts in improving the government finance statistics, especially placing emphasis on the Mission's recommendations to be supplemented at the earliest possible time.

However, we hope you understand that statistics can vary from country to country due to wide differences in every respect of society of their own.

For instance, following to the IMF manual, although it is recommended to compile the general government statistics by the end of June in the following year, given the situation of 
Korea such as the period of budget account settlement of local governments (submit to the local council at the end of June in the following year), it is realistically difficult to disseminate the general government statistics by June.

Nevertheless, the MOSF is committed to meeting the IMF standard, and we expect your understanding of our continuous efforts.

In terms of disclosure of this report, we agree to make it public if our opinion stated in Volume II is attached as it is.

In addition, it would be greatly appreciated if you consider that using the ROSC data modules for ranking the data quality of member countries is inappropriate when they are published.

\section{Plans For Future Statistical Development}

\section{A. National Accounts}

Regarding the Denton Method after reviewing its feasibility and some technical issues, the $\mathrm{BOK}$ is to consider using it for the original data in order to adjust quarterly estimates to agree with annual benchmark estimates as for the seasonally adjusted data.

The BOK has been undertaking developmental work on the National balance sheet for the last few years and the results of the work will be released in the near future. Consequently, the estimates for consumption of fixed capital can then be derived using the Perpetual Inventory Method (PIM) once the capital stock data from the National balance sheet statistics are available.

The BOK does not consider that the non-observed economy (NOE) is a major issue in the Korean national accounting system, so will not take any specific actions to estimate the NOE for the time being. However, the BOK will keep trying to capture the scale of the NOE as far as possible using a variety of approaches such as expanding self-survey samples within service industries and developing new source data.

Also, the BOK is conducting a pilot test to compile the supply-use tables (SUT) directly. Therefore, the statistical discrepancy between GDP by production activities and GDP by expenditure could be removed at the time of use of a SUT framework.

Currently, the BOK analyzes the differences between the initial estimates and the revised estimates for a short time period quarterly and annually, while a revision study for a long time series has only been undertaken once in 2006. In the future, the BOK will undertake similar revision studies periodically. 


\section{B. Consumer Price Index}

Access the Korean Statistical Information System (KOSIS): The KOSTAT establishes the new data-base system for international users to open it by the end of 2010. After then, they access the KOSIS free of charge without downloading additional software.

Carry forward for seasonal products: The statistical techniques could vary from country to country upon cultural, environmental, and social wide differences. As Korea has four distinct seasons, the KOSTAT uses the carry-forward method for seasonal products which possess clear seasonal patterns. In particular, agricultural products could not be replaced with any other products. Since the KOSTAT has thoroughly reviewed the consumption patterns and market distribution for seasonal products to revise the CPI every five years, the KOSTAT concludes the carry-forward is practically the best method for them. To prepare the 2010 rebase of CPI, the KOSTAT studies various methodologies for seasonal products.

Consult widely users: About statistical methodologies and major changes for revising the CPI, the KOSTAT consults the National Statistics Committee (NSC) which consists of the Ministers, the Governor of the Bank of Korea, and professionals in academic field.

Considering your recommendations, the KOSTAT will discuss them with the NSC for 2010 rebase of the CPI.

Assess the feasibility of farming and fishing households: Because the fishing households account for less than 1 percent of total Korean households, the KOSTAT does not include them in the CPI. After the KOSTAT examines and compares expenditure patterns of the Farm Household Economic Survey and the Household Income and Expenditure Survey, the KOSTAT will decide whether to include the farming households in the CPI or not.

Change weights from a five-yearly to a three-yearly: While revising the weights and items of the CPI every five years ending in 0 or 5 , the KOSTAT will change only weight of CPI every five years ending in 3 or 8 from 2013. Like regular revision of the CPI, the KOSTAT will hold the NSC and evaluate the effects of change.

\section{Producer Price Index}

Compiling Korean Central Product Classification (KCPC) is undertaken by the Statistics Korea, which has recently been pursuing this project through discussions with the organizations concerned. The application of KCPC to the PPI will be feasible only after the Report on Mining and Manufacturing Survey, the elementary data for the estimation of PPI weightings, is itself performed by KCPC. Implementing the KCPC for the 2010 PPI rebase in 2013 remains problematic because there is no possibility in sight of compiling Report on Mining and Manufacturing Survey according to the KCPC.

The BOK uses carry-forward for imputing temporarily missing prices for both regular and seasonal products. The BOK was already aware of the weaknesses in this, so it is involved in a study of appropriate methods of imputing missing prices for both regular and seasonal products. 
To remove the upward bias that results from use of an arithmetic average, the BOK compiles a supplementary index calculated using a geometric mean. There may well be pros and cons in changing the component products and formulae so the BOK is going to review the influence of such a move. And, once chain index PPI is compiled, the problem of upward bias derived from use of an arithmetic mean will disappear.

The BOK compiled an experimental chain Laspeyres index in 2009, and will continue to do so for the next few years. During the period of experimental compilation, it will counter the effects of substitution bias and assess the reliability.

In metadata documentation, it will be explicitly noted that products included in the PPI are classified by the Korean Standard Industrial Classification (KSIC) and so on.

\section{Government Finance Statistics}

Periodicity and Timeliness: As the period of budget account settlement of the Korea's local governments is after June in the following year, it is difficult to disseminate the general government statistics including local governments by June. Therefore, given the situation of Korea, it is considered that disseminating the statistics by November of the following year is realistically acceptable.

Consistency: The Korean government is processing the task reconciling the range of government debt and fiscal balance, and it will be completed at the end of this year. Based on this statistical reforming work, the identical range will be applied from 2012 when statistics are compiled according to the GFSM 2001.

Data Accessibility: Following the SDDS, as the Korean government has in principle disseminated the central government statistics by the end of next month and the general government statistics by the end of November of the following year, it is unnecessary to publish release calendars. However, for users' convenience, release calendars of fiscal statistics will be provided in future.

Metadata Accessibility: Metadata of the general government are posted on the website. Additionally, as it will be published through the '2010 Korea's Integrated Fiscal Balance' booklet during the third quarter of 2010 , accessibility to the general government metadata will be enhanced.

\section{E. Monetary Statistics}

The BOK has so far recorded all Foreign Exchange Stabilization Fund (FESF) flows and stocks in the central bank accounts. However, after 2012, with the implementation of the BPM6, the GFSM 2001 and the SNA 2008, all FESF flows and stocks will be included in the central government accounts in the monetary statistics, BOP, IIP, GFS and the National accounts and treated consistently at all stages. 
In the BOK balance sheet, all marketable financial instruments are recorded at book value, and assets and liabilities denominated in foreign currencies are revalued twice a year, at the end of June and December. The accounting treatment is consistent with the BOK's accounting policies and cannot be varied for monetary statistics purposes unless the accounting policies are changed.

The BOK is working on combining the accounts of the commercial \& specialized banks and the nonbank depository corporations into the Other Depository Corporations Survey (ODCS). In the ODCS, the BOK will present claims on the BOK, and liabilities to the BOK on the assets and liabilities side, respectively, and will also try to introduce regular crosschecking procedures of positions between the BOK and the ODCs, as well as positions among the ODCs.

The name of "reserve money" has already been changed into "monetary base". Financial instruments included in broad money will be aligned with the following MFSM defined instruments - Currency in circulation, Transferable deposits, Other deposits, and Securities other than shares - in the relevant statistics.

The BOK will draw up measures to withdraw the SDDS flexibility option.

\section{F. Balance of Payments Statistics}

The BOK has compiled data only for foreign branches of domestic banks on reinvested earnings. However, it has compiled annual experimental data on all transactions on reinvested earnings. The BOK plans to disseminate them in 2012 when migrating to the BPM6 is scheduled.

The BOK has compiled data only for certain enterprises such as airlines and shipping companies on foreign currency transactions of enterprises through accounts held abroad. However, it intends to carry out sample surveys on foreign currency transactions of enterprises with relatively large sums held in accounts abroad, and disseminate the data in 2012 when migrating to the BPM6 is scheduled.

The BOK plans to estimate data on trade credits of affiliated enterprises using the proportion of trade credits between affiliated enterprises, which can be obtained from the direct investment survey, to the trade credits of all enterprises. The BOK is going to publish them in 2012 when migrating to the BPM6 is scheduled.

Regarding short-term loans of affiliated enterprises, the BOK has already reclassified them as other capital in direct investment.

Regarding the basis of recording of income transactions, the BOK has partially adopted the accrual basis to be consistent with the Balance of Payments Manual. It also plans to take further steps to improve the current method. 
The BOK will make full use of all available systems of cooperation among the related agencies to maintain data consistency during the migration process towards the new methodology such as BPM6 or SNA 2008.

The BOK has so far recorded all FESF flows and stocks in the central bank accounts. However, after 2012, with the implementation of the BPM6, the GFSM 2001 and the SNA 2008, all FESF flows and stocks will be included in the central government accounts in the monetary statistics, BOP, IIP, GFS and the National accounts and treated consistently at all stages. 
INTERNATIONAL MONETARY FUND

REPUBLIC OF KOREA

Report on the Observance of Standards and Codes (ROSC)—Data Module Volume III

\author{
Detailed Assessments Using the Data Quality Assessment Framework (DQAF) \\ Prepared by the Statistics Department \\ Approved by Adelheid Burgi-Schmelz and Anoop Singh
}

July 8, 2010

This document contains a detailed assessment by dataset of the elements and indicators that underlie the data quality dimensions discussed in Korea's Report on the Observance of Standards and Codes (ROSC)—Data Module. It also includes as appendices the summary of the Special Data Dissemination Standard (SDDS), the DQAF generic framework, and the results of the users' survey. 


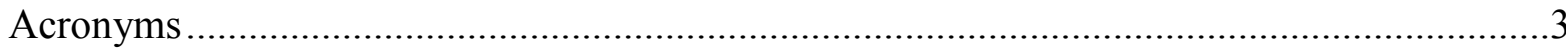

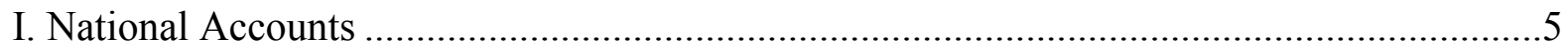

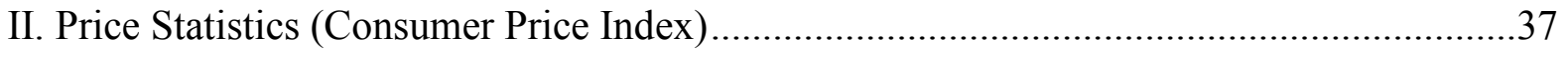

III. Price Statistics (Producer Price Index) ...................................................................54

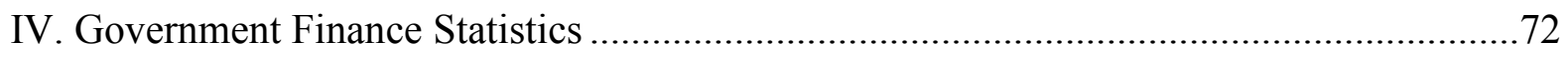

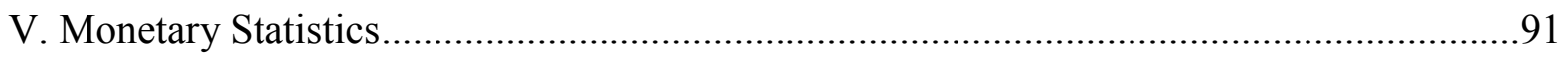

VI. Balance of Payments Statistics ...................................................................... 114

Tables

1. Data Quality Assessment Framework (July 2003): Summary of Results for

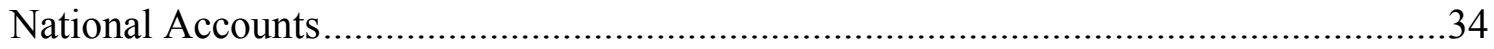

2. Data Quality Assessment Framework (July 2003): Summary of Results for

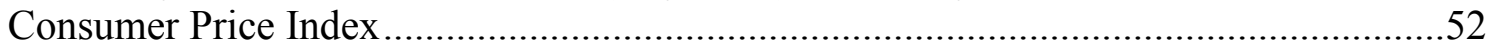

3. Data Quality Assessment Framework (July 2003: Summary of Results for

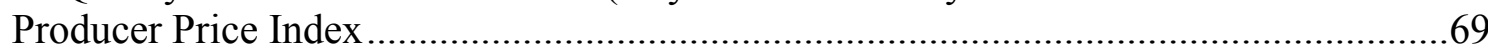

4. Data Quality Assessment Framework (July 2003): Summary of Results for

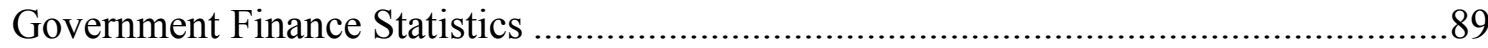

5. Data Quality Assessment Framework (July 2003: Summary of Results for

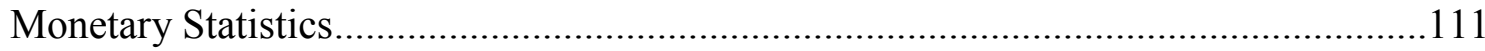

6. Data Quality Assessment Framework (July 2003): Summary of Results for Balance of Payments Statistics

Appendices

I. User's Survey ....

II. Summary of the Special Data Dissemination Standard (SDDS) ....................................141

III. Data Quality Assessment Framework - Generic Framework.......................................143

IV. Results of Korea's User Survey, December 2009 .......................................................146 


\section{ACRONYMS}

1968 SNA

1993 SNA

2003 SNA

2008 SNA

BAI

BARO

BMD

BOK

BOP

BPM5

BPM6

c.i.f.

COFOG

COICOP

$\mathrm{CPC}$

CPD

CPI

CPIM 2004

CPS

DBAS (dBrain)

DCS

DMBs

DQAF

DSBB

EAPS

ECOS

ESD

f.o.b.

FEIS

FESF

FIES

FISIM

FSA

FSS

FYLG

GDP

GFCF

GFS

GFSK

GFSM 1986

GFSM 2001

GFSY

GPAPD
A System of National Accounts, 1968

System of National Accounts, 1993

System of National Accounts, 2003

System of National Accounts, 2008

Board of Audit and Inspection

Budget and Accounting Renovation Office (MOSF)

Budget and Management Department, Bank of Korea

Bank of Korea

Balance of Payments

Balance of Payments Manual, Fifth Edition

Balance of Payments and International Investment Position Manual, Sixth Edition

Cost, insurance, and freight

Classifications of the Functions of Government

Classification of Individual Consumption by Purpose

Central Product Classification

Consumer Price Division

Consumer Price Index

Consumer Price Index Manual, 2004

Consumer Price Survey

Digital Budget and Accounting System

Depository Corporations Survey

Deposit Money Banks

Data Quality Assessment Framework

Dissemination Standards Bulletin Board

Economically Active Population Survey

Economic Statistics System, Bank of Korea

Economic Statistics Department, Bank of Korea

Free on board

Foreign Exchange Information System

Foreign Exchange Stabilization Fund

Family Income and Expenditure Survey

Financial Intermediation Services Indirectly Measured

Financial Services Authority

Financial Supervisory Service

Financial Yearbook of Local Government

Gross Domestic Product

Gross fixed capital formation

Government Finance Statistics

Government Finance Statistics in Korea

A Manual on Government Finance Statistics, 1986

Government Finance Statistics Manual, 2001

Government Finance Statistics Yearbook

Government Procurement and Accounting Policy Division 


$\begin{array}{ll}\text { HIES } & \text { Household Income and Expenditure Survey } \\ \text { IIP } & \text { International Investment Position } \\ \text { ILO } & \text { International Labor Organization } \\ \text { I-O } & \text { Input-output } \\ \text { IPI } & \text { Industrial Production Index } \\ \text { ISIC } & \text { International Standard Industrial Classification } \\ \text { KCPC } & \text { Korean Central Product Classification } \\ \text { KCS } & \text { Korea Customs Service } \\ \text { KDIC } & \text { Korean Deposit Insurance Corporation } \\ \text { KEPCO } & \text { Korea Electric Power Corporation } \\ \text { KFX } & \text { Foreign Exchange Transactions reporting system } \\ \text { KOICA } & \text { Korean International Cooperation Agency } \\ \text { KOSIS } & \text { Korean Statistical Information System } \\ \text { KOSTAT } & \text { Statistics Korea } \\ \text { KOTRA } & \text { Korea Trade Investment Promotion Agency } \\ \text { KSIC } & \text { Korean Standard Industrial Classification } \\ \text { KTS } & \text { Korean Tax Service } \\ \text { LBIS } & \text { Local Budget Information System } \\ \text { MAA } & \text { Monetary Authorities' Account } \\ \text { MAF } & \text { Ministry of Agriculture and Forestry } \\ \text { MBP } & \text { Ministry of Budget and Planning } \\ \text { MFSM } & \text { Monetary and Financial Statistics Manual, 2000 } \\ \text { MCIE } & \text { Ministry of Commerce, Industry, and Energy } \\ \text { MEST } & \text { Ministry of Education, Science, and Technology } \\ \text { MKE } & \text { Ministry of Knowledge Economy } \\ \text { MOSF } & \text { Ministry of Strategy and Finance } \\ \text { MOPAS } & \text { Ministry of Public Administration and Security } \\ \text { MPI } & \text { Import Price Index } \\ \text { NAFIS } & \text { National Financial Information System } \\ \text { NAIS } & \text { National Audit and Inspection Information System } \\ \text { NFPEs } & \text { Nonfinancial Public Enterprises } \\ \text { NPISH } & \text { Nonprofit Institutions Serving Households } \\ \text { NSDP } & \text { National Summary Data Page } \\ \text { OECD } & \text { Organization for Economic Co-operation and Development } \\ \text { OFIs } & \text { Other Financial Institutions } \\ \text { PIM } & \text { Perpetual inventory method } \\ \text { PPI } & \text { Producer Price Index } \\ \text { PPIM } 2004 & \text { Producer Price Index Manual, 2004 Price Index } \\ \text { PSD } & \text { Price Statistics Division } \\ \text { SDDS } & \text { Special Data Dissemination Standard } \\ \text { SOP } & \text { Stage of Processing } \\ \text { STA } & \text { Statistics Department, IMF } \\ \text { UN } & \text { Enited Nations } \\ \text { XPI } & \end{array}$




\section{Detailed Assessment Using the DAta Quality Assessment Framework (DQAF)}

The following detailed information on indicators of statistical practices in the areas of the national accounts, prices, and government finance, monetary, and balance of payments statistics was gathered from publicly available documents and information provided by the Korean officials who met the STA mission during December 8-22, 2009. This information, which is organized along the lines of the generic DQAF (see Appendix II), was used to prepare the summary assessment of data quality elements, based on a four-part scale of observance, shown in Korea' s Report on the Observance of Standards and Codes (ROSC) Data Module.

\section{National Accounts}

\section{Prerequisites of quality}

\subsection{Legal and institutional environment}

\subsubsection{The responsibility for collecting, processing, and disseminating the statistics is clearly specified}

National accounts statistics are compiled in accordance with Article 86 of the Bank of Korea Act (2004) which states that "The Bank of Korea may, when necessary for the formulation of its monetary and credit policies, collect and compile statistics on money and banking, public finances, prices, wages, production, the balance of payments, and other basic economic statistical series and conduct economic research and for such purposes request any materials or information from government organizations and any juristic or individual person." Article 42 of the General Banking Act states the terms under which commercial and specialized banks are to submit balance-sheet accounts to the BOK and that the BOK may publish the reported data. In addition, the Statistics Act (2009) specifies all aspects of the production of statistics in Korea. Article 15 describes conditions for the designation of designated statistics collecting agencies; and Article 18 governs conditions for the collection and dissemination of statistics. Under Article 15 of the Statistics Act, the Commissioner of Statistics Korea has designated the BOK as the official compiling agency for the national accounts. As a designated agency the BOK is governed in its statistical work also by the remaining provisions of the Statistics Act.

\subsubsection{Data sharing and coordination among data-producing agencies are adequate}

The BOK has established close relationships with data suppliers for the smooth and timely flow of source data. The BOK regularly consults with Statistics Korea (KOSTAT), which supplies a wide range of census and survey data. Meetings are also held with KOSTAT concerning possible improvements in the quality of source data. Moreover, the BOK emphasizes the importance of the national accounts statistics and source data with other data-producing agencies, such as the Ministry of Strategy and Finance (MOSF), the Korean Tax Service (KTS) and industrial associations, through formal and informal meetings, lectures, and education programs. 


\subsubsection{Individual reporters' data are to be kept confidential and used for statistical purposes only}

The confidentiality of individual respondents' data collected by the BOK is guaranteed by the Statistics Act (Articles 33 and 34), which requires that material of a confidential nature belonging to individuals, juristic persons, or organizations collected for statistical compilation shall be protected from disclosure and used only for statistical compilation.

All BOK staff are bound by the Bank of Korea Act, Article 42, which specifies that they should not divulge confidential matters to outsiders. Similar provisions are contained in Article 20 of the Articles of Incorporation of the BOK, as well as in the code of conduct of the staff. All staff must take a written oath to commit to follow the code of conduct.

The Guidelines on Compilation and Dissemination of Statistics (September 1999), prepared by the management of the BOK's Economic Statistics Department (ESD), provides specific guidelines for the compilation and dissemination of statistics. In particular, access to confidential data is restricted to staff directly involved, through restricting access to offices, and ensuring computer security. New staff, including temporary staff, are apprised of the guidelines.

The integrity of the staff is held as of critical importance at the highest levels of the BOK. Any breach of confidentiality would be likely to be reported in detail in the newspapers; to date, there have been no such breaches. Under the Statistics Act, Article 39, breaches of confidentiality may result in imprisonment.

In the surveys administered by the National Income Statistics Team of the BOK's ESD, respondents are informed that the data requested will be held in confidence and used only for statistical purposes. In new surveys, respondents are informed of the purpose of the survey, the importance of the national accounts statistics, and the legal basis for the collection.

\subsubsection{Statistical reporting is ensured through legal mandate and/or measures to encourage response}

The Bank of Korea Act, Article 87, and the Statistics Act collectively provide the legal basis for the collection of statistical information for compiling statistics. In the conduct of statistical collections, the BOK explains to survey respondents the importance of the data being sought for policy formulation in order to encourage response, and has found the approach mostly successful. However, the BOK has no legal power itself to impose penalties for non-compliance with statistical reporting requirements. Under the Statistics Act, Article 41, KOSTAT can impose fines for nonresponse to reasonable requests. The BOK can ask KOSTAT to levy such penalties on its behalf, but so far has never needed to do so. 


\section{$0.2 \quad$ Resources}

\subsubsection{Staff, facilities, computing resources, and financing are commensurate with statistical programs}

The National Income Statistics Team has 29 regular staff and nine temporary contract employees. Data for the general government sector are compiled by the Statistics Development Team. Input-output (I-O) tables are compiled by a separate team in the ESD that has a staff of 19 officers. Annual and quarterly flow of funds statistics are produced by another area of the ESD. The development of national balance sheets is being undertaken by a separate team of six officers.

There are adequate staff resources to compile national accounts, including the prospective migration to the $2008 S N A$ in 2014 at the time of the next rebasing exercise from reference year 2005 to 2010 .

The BOK takes every opportunity to send staff on international training courses, seminars, and workshops. A separate budget is available to the ESD for these purposes. Most knowledge of compilation is built up from the job manuals which explain the concepts, classification, compilation process, and computer programming. These manuals are regularly updated by each current compiler to reflect any changes in the compilation process and handed over to new compilers with explanation and coaching. The BOK also undertakes its own training in general statistical matters, including national accounts. Salaries are competitive in the BOK, so it does not have a serious issue in retaining staff or obtaining funding for statistical development. Available computer resources are adequate.

\subsubsection{Measures to ensure efficient use of resources are implemented}

In October of each year, the National Income Statistics Team prepares its budget for the following year, which the BOK's Planning Department evaluates. During the year, the program and use of resources are monitored on a quarterly basis. The program is reviewed annually. Reviews of staff performance are conducted twice a year, and staff receive differentiated bonuses based on the assessment results. During the reviews, assessors evaluate whether staff have undertaken their jobs in a resource efficient manner and in accordance with their work manuals. On occasion, outside consultants are used, for instance, to develop statistical compilation systems.

\section{$0.3 \quad$ Relevance}

\subsubsection{The relevance and practical utility of existing statistics in meeting users' needs are monitored}

The BOK holds a National Accounts Advisory Committee meeting twice a year, which is made up of representatives from the BOK, government agencies, universities, and research institutes. Its purpose is to obtain views about the quality of national accounts statistics and to receive advice on proposed improvements to the accounts and other new developments. In 
addition, the BOK holds consultation meetings and seminars with users. The BOK actively participates in statistical meetings and seminars organized by international organizations such as the UN, the IMF, and the OECD in order to keep up with international issues and other countries' experiences in compiling the national accounts. As a member of the Korea Statistical Society the BOK encourages its staff to present research papers on national accounts at meetings of the Society.

The BOK uses its Economic Statistics System (ECOS: http://ecos.bok.or.kr) website to communicate with users. Users can submit questions and comments about economic statistics at this website. In addition, surveys about users' needs are conducted regularly through this site. The BOK may also receive feedback from the regular program of contacts that KOSTAT maintains with users.

\subsection{Other quality management}

\subsubsection{Processes are in place to focus on quality}

In order to improve the quality of statistics, the Statistics Act, Articles 9 and 10, mandates regular and one-off evaluations. The BOK conducts an Independent Quality Evaluation every five years and a Quality Self-Evaluation every year. It also periodically participates in international evaluations, such as the IMF's Data ROSC program. The BOK has established three internal committees to assist in research and to promote quality: the Quality Evaluation Advice Committee, the Source Data Improvement Committee, and the Seasonal Adjustment Committee.

\subsubsection{Processes are in place to monitor the quality of the statistical program}

The Audit Department of the BOK regularly reviews the consistency and accuracy of the published statistics, together with the level of budget and expenses. The Economic Statistics Department prepares the annual and long-term plans for the statistical program, and the Budget and Management Department checks the conduct of these plans quarterly.

In order to improve statistical quality continuously, the BOK established the Plan for developing and improving economic statistics in July, 2009 and has participated in the Midto long-term development plan for national statistics organized by KOSTAT.

\subsubsection{Processes are in place to deal with quality considerations in planning the statistical program}

When the BOK plans its statistical programs, quality issues are addressed explicitly and given priority consideration. Tradeoffs among the dimensions of quality (e.g., resource availability, timeliness, and accuracy/reliability) are recognized. 


\section{Assurances of integrity}

\section{$1.1 \quad$ Professionalism}

\subsubsection{Statistics are produced on an impartial basis}

The national accounts statistics are compiled on an impartial basis. By the Bank of Korea Act, Article 3, the BOK is independent from the government in its operations, and this independence is personally stressed by the highest levels of the BOK. There is no external pressure on the BOK with respect to the content or release of the statistics. Staff are encouraged to prepare research papers on statistical issues that are published under their names; seminars and conferences are arranged at which staff and outside experts participate.

\subsubsection{Choices of sources and statistical techniques, as well as decisions about dissemination, are informed solely by statistical considerations}

The choices of sources, statistical techniques, and dissemination of national accounts are made freely by the BOK, and informed solely by statistical considerations. The BOK staff are highly professional, and make independent decisions on statistical matters.

\subsubsection{The appropriate statistical entity is entitled to comment on erroneous interpretation and misuse of statistics}

The BOK provides explanatory materials and press briefings to the media when releasing the national accounts statistics. The BOK monitors media coverage of its statistical products daily. Where there is an erroneous interpretation of statistics, the BOK seeks correction from the media. It also issues its own press releases to correct misinterpretation or misuse of statistics.

\subsection{Transparency}

\subsubsection{The terms and conditions under which statistics are collected, processed, and} disseminated are available to the public

The Bank of Korea Act and the Statistics Act are available on the websites of the BOK (http://www.bok.or.kr) and KOSTAT (http://www.kostat.go.kr). Detailed descriptions of the methodologies and techniques used are presented on these websites and in various publications such as Korean System of National Accounts, Understanding and Use of Economic Statistics, and Quarterly National Accounts in Korea. These publications also contain information to assist users (e.g., contact person and internet address of the BOK and the BOK's ECOS). The ESD also maintains an Information Center where users can obtain additional information on economic statistics. 


\subsubsection{Internal governmental access to statistics prior to their release is publicly identified}

The BOK disseminates the national accounts statistics to all users simultaneously. The statistics are not provided to anyone, including government agencies, before release.

\subsubsection{Products of statistical agencies/units are clearly identified as such}

The BOK's publications and press releases clearly identify the BOK as the publisher by name, logo, and insignia.

\subsubsection{Advance notice is given of major changes in methodology, source data, and statistical techniques}

Advance notice is provided to the press, or through the BOK's website, when the BOK is preparing a major change in methodology, source data, or statistical technique. Examples where advance notice was provided in advance of such changes include the introduction of seasonally adjusted estimates; of the annual chain linking method; and the implementation of the 1993 SNA methodology.

\subsection{Ethical standards}

\subsubsection{Guidelines for staff behavior are in place and are well known to the staff}

There are clear ethical guidelines for official statistics in the Guidelines on Compilation and Dissemination of Statistics, first issued to all staff in September 1999. This document is given to all new staff including contract workers, and displayed in work areas. Periodically, the Personnel Department will remind staff of aspects of professional behavior. High ethical standards are expected of, and observed by, the BOK staff.

\section{Methodological soundness}

\subsection{Concepts and definitions}

\subsubsection{The overall structure in terms of concepts and definitions follows internationally} accepted standards, guidelines, or good practices

In 2004, the Korean national accounts system transferred from the 1968 SNA to the 1993 SNA. Chain volume estimates were introduced in March 2009 in conjunction with the rebasing from 2000 to 2005 . The national accounts are currently compiled in accordance with the $1993 S N A$ in terms of concepts and definitions. It is intended to implement the $2008 \mathrm{SNA}$ in 2014, when the accounts are rebased from 2005 to 2010. 


\section{$2.2 \quad$ Scope}

2.2.1 The scope is broadly consistent with internationally accepted standards, guidelines, or good practices

The 1993 SNA tables and accounts that the Inter-secretariat Working Group on National Accounts (ISWGNA) determined as the minimum requirement for its implementation, as listed below, are compiled on a regular basis:

- Annual value added and gross domestic product (GDP) at current and constant prices by activity.

- Annual expenditures of GDP at current and constant prices.

- Annual value added components at current prices by activity.

- $\quad$ Sequence of accounts for the total economy (up to financial accounts) with an annual frequency.

- Annual rest-of-the-world accounts (up to net lending).

The 1993 SNA tables and accounts that the ISWGNA determined as recommended for its implementation, as listed below, are compiled on a regular basis, except that annual supply-and-use (SUT) tables are not currently compiled:

- Quarterly value added and GDP at current and constant prices by activity.

- Quarterly expenditures of GDP at current and constant prices.

- $\quad$ Annual SUT tables.

Benchmark I-O accounts on a product-by-product basis are produced every five years, based on direct investigation and surveys of transactions between industries to give detailed input structures. SUT tables are derived from the benchmark using various available source data and mathematical techniques. Since 2005, annual I-O tables are derived from the benchmark using a much reduced survey of input structures and indirect methods. ${ }^{1}$ Targeted surveys are carried out for those sectors where input structures are expected to have changed significantly. The BOK also consults industry experts as part of this process. Currently, the BOK is conducting a pilot survey to compile SUT tables directly. The reference year for this has not yet been decided.

\footnotetext{
${ }^{1}$ This is a widely used technique that allows for the introduction of new information to update I-O and SUT matrices.
} 
In addition, production, income, and capital accounts are published annually by institutional sector.

The delimitation of the constituent units of the economy is in accordance with the $1993 \mathrm{SNA}$. Territorial enclaves in the rest of the world, free trade zones, and workers who work part of the year in another country are included. The production boundary is in accordance with the $1993 S N A$. In particular, own-account production of goods for own final consumption, research and development on own account, output of goods for own-account fixed capital formation, mineral exploration, computer software and entertainment literary or artistic originals are included. However, there are insufficient data to allow the inclusion of illegal activities within the production boundary.

The asset boundary is generally in agreement with the $1993 S N A$. However, no capital formation estimates are included for historical monuments, or for entertainment, literary or artistic originals. Works of art are not included in estimates for valuables.

\subsection{Classification/sectorization}

\subsubsection{Classification/sectorization systems used are broadly consistent with internationally accepted standards, guidelines, or good practices}

The classification of institutional units, transactions and other flows are in accordance with the 1993 SNA. The private nonprofit institutions serving households (NPISH) sector is identified as a separate sector in the production accounts, but it is combined with households in the income and capital accounts. The classification of economic activities is based on the Korean Standard Industrial Classification (KSIC) (1 February 2008) which is consistent with the International Standard Industrial Classification (ISIC), Rev.4. The product classification used when compiling the I-O tables is compatible with the Central Product Classification. The Classification of Individual Consumption by Purpose (COICOP) and the Classification of the Functions of Government (COFOG) are used to classify household consumption and the functions of government, respectively.

\subsection{Basis for recording}

\subsubsection{Market prices are used to value flows and stocks}

Market output and output for own uses are valued at basic prices and at equivalent market prices, respectively. Intermediate consumption and final uses are valued at purchasers' prices including levied sales/excise taxes and value added taxes with the deductible part excluded. Korean tax law prescribes that transactions between establishments within the same enterprise are to be valued at market prices, so no adjustments are required for transfer pricing. Total imports and exports are valued on an f.o.b. basis, and information on insurance and freight for merchandise imports is available. Imports and exports of goods in US dollars are converted to Korean won using average daily market exchange rates multiplied by daily 
trading values, while average monthly market exchange rates multiplied by monthly trading values are used for imports and exports of services.

\subsubsection{Recording is done on an accrual basis}

Transactions and flows are recorded on an accrual basis and work-in-progress is recorded in the period that it is produced. General government taxes and subsidies on products, and expenditure and revenue data, which are recorded on a cash basis, are adjusted to an accrual basis.

\subsubsection{Grossing/netting procedures are broadly consistent with internationally accepted standards, guidelines, or good practices}

Transactions between establishments within the same enterprise are recorded on a gross basis, consistent with international standards.

\section{Accuracy and reliability}

\subsection{Source data}

\subsubsection{Source data are obtained from comprehensive data collection programs that take into account country-specific conditions}

A centralized business register for statistical surveys is maintained by conducting an annual units census of establishments. The establishments are identified visually using a team of local government interviewers (about 9000 interviewers were used in 2008). The register contains detailed information for establishments.

KOSTAT undertakes industrial censuses every five years (years ending in 3 and 8) covering mining, manufacturing, electricity, gas, and water supply, and service industry censuses every five years (years ending in 0 and 5) covering all service industries except construction, transport, public administration and defense, and compulsory social security. All establishments with one or more workers are surveyed, except for publicly-owned establishments which are covered in the central government data supplied by the MOSF. A population and housing census is also conducted every five years (years ending in 0 and 5) that provides data for the household sector, including rentals.

KOSTAT conducts annual establishment surveys covering all industries except construction and transport. For construction and transport, annual surveys are conducted on an enterprise basis. All sizes of establishment are within the sample frames, except for mining and quarrying, and manufacturing. In these two industries, establishments with less than ten employees are excluded, but all other businesses are fully enumerated. Proper sampling techniques are used in all surveys.

KOSTAT undertakes monthly or quarterly surveys for some important industries, as noted below. The Financial Statement Survey conducted annually and quarterly by the BOK covers 
almost all industries except for agriculture, forestry and finance and its results are widely used in the compilation of quarterly and annual national accounts. The value added ratio of industries such as manufacturing, wholesale trade, retail trade, and hotels and restaurants, is derived from the results of the survey, which covers almost all large companies. The small companies surveyed are chosen by stratified random sampling among companies with sales of more than 2.0 billion won.

Agriculture There is a monthly data collection system, the Farm Household Economy Survey, for household farmers. However, the results are not reported to KOSTAT until after the end of the year. The data collected include sales, purchases, and assets. A sub-sample of this survey, the Production Cost Survey of Agriculture Products, is conducted following the same reporting arrangements. This survey collects a breakdown of purchase costs by household farmers for a range of specific crops.

Forestry and Fishing KOSTAT conducts a monthly survey, the Fishery Production Survey on the quantity and value of production, of all types of fishing activity undertaken by households, cooperatives, and enterprises. Another KOSTAT monthly survey, the Fishery Household Economy Survey, collects data on sales, purchases, and assets.

Mining and quarrying and manufacturing A monthly sample survey of these industries is conducted by KOSTAT of the value and volume of production, sales and inventories. This survey is used to construct the Industrial Production Index (IPI). The BOK also undertakes special quarterly surveys from manufacturing companies and from eight mining federations.

Electricity, gas, and water supply Quarterly data for electricity are obtained from the financial statements of the Korea Electric Power Corporation. For those firms that generate electricity for their own final use, the data collected relate only to the quantity generated each quarter. For the gas and water producers, quarterly figures for sales values and quantities are obtained directly from the companies providing those services. The BOK conducts a full census each quarter of all major enterprises in electricity, gas, and water supply.

Construction Various monthly and quarterly data sources are used for compiling estimates for construction. Data on the monthly output of building construction are obtained from KOSTAT (Monthly Construction Trends) and the Ministry of Land, Transport and Maritime Affairs. The MOSF provides monthly data on the output of central government civil engineering, while the Ministry of Public Administration and Security (MOPAS) provides similar data for local government. The BOK also conducts a quarterly sample survey from large private sector companies engaged in civil engineering.

Wholesale and retail trade KOSTAT conducts a monthly survey of the sales of these industries. Its results are used to construct the Service Industry Activity index for these industries.

Restaurants and hotels KOSTAT conducts a monthly survey, the Service Industry Activity Index, on the value of sales. The BOK also conducts its own quarterly survey of large hotels. 
Finance and insurance Enterprises in this industry supply the BOK with quarterly financial statements, in connection with the BOK's regulatory functions. These enterprises therefore are not covered in the BOK's general Financial Statement Survey.

Transport and communications Quarterly data on sales values are collected either from the enterprises, e.g., the National Railroad Office, BOK surveys, or from trade organizations. The BOK conducts quarterly surveys covering maritime transport (full census), other transport and storage (sample survey of large companies) and information and communication (sample survey of large companies).

Other services Quarterly sales data are available from a number of sources. For some sub-industries the data are from the BOK's own quarterly survey which also uses the KOSTAT register as the sample frame. For most sub-industries, monthly data are available from the Service Industry Activity Index conducted by KOSTAT. Also, data are obtained from trade organizations and the MOSF for government operations.

The BOK uses data from the Household Income and Expenditure Survey (HIES) conducted monthly by KOSTAT. The classification of expenditure items in the HIES is in accordance with COICOP and the results of the HIES are released quarterly. The survey population is households residing in the country except for farming/fishing households and foreigners' households. The monthly HIES covers 89 percent of all households in the country, since it began including single-person households in 2006. Its population frame is the Population and Housing Census conducted in 2005. The HIES has a sample size of 9,000 households. It uses proper sampling and processing techniques, and collects information on income, occupation, and detailed expenditure. There is in addition an annual collection from farm households that is added to the ongoing monthly HIES results at the end of the year, which brings the coverage of the HIES to 96 percent of all households.

As indicated above, the BOK undertakes about 12 special quarterly surveys across a wide range of industries, mainly covering large companies, in order to obtain data that are not available from other sources. Often these surveys are initiated out as ad-hoc surveys, but later become regular $\mathrm{BOK}$ collections.

Detailed government data including the operation of extra-budgetary funds, defense related expenditures, and local government operations are available to measure output, intermediate consumption, fixed capital formation, and final consumption expenditure of government services. Capital stock and consumption of fixed capital are estimated using the perpetual inventory method (PIM).

Price statistics used as deflators, such as the Consumer Price Index (CPI), Producer Price Index (PPI), Export Price Index (XPI), and Import Price Index (MPI) are available at a sufficiently detailed level for the compilation of the national accounts. Price statistics are generally consistent with the variables being deflated in terms of the price concept, coverage, and reference period. In some cases when a specific index is not available for an aggregate, mixed or compound indices are derived using relevant components from the available indices. 
When estimating quarterly GDP by kind of economic activity, the BOK mainly uses KOSTAT's monthly survey data, such as the IPI of mining and manufacturing, the Service Industry Activity Index and the Construction Industry Trend survey. For the quarterly expenditure on GDP, the BOK mainly uses KOSTAT's survey data (e.g., monthly sales index of consumption goods, quarterly HIES, and the monthly Index of Equipment Investment), the BOK's monthly balance of payments (BOP) statistics, and the monthly merchandise trade statistics from the Korean Customs Service (KCS). Adequate monthly and quarterly data are available for compiling quarterly GDP.

The BOK seeks to remain up-to-date in the national accounts compilation system by visiting a selection of enterprises each quarter, monitoring the press and research papers, participating in international conferences held by international organizations, and by consulting with the data supplying agencies.

The two tables below provide a summary of the major data sources used to compile the current price production and expenditure measures of annual and quarterly GDP together with an assessment of these various sources.

Text Table 1: Main Sources for the Annual Accounts

\begin{tabular}{|l|l|l|}
\hline \multicolumn{2}{|c|}{ Production Approach } \\
\hline $\begin{array}{l}\text { Korean Standard } \\
\text { Classification }\end{array}$ & Main Source & $\begin{array}{l}\text { Adequacy for } \\
\text { Annual } \\
\text { Estimates }\end{array}$ \\
\hline $\begin{array}{l}\text { Agriculture, forestry fishing } \\
\text { and }\end{array}$ & $\begin{array}{l}\text { Production quantities (Crop Production Survey - } \\
\text { KOSTAT); } \\
\text { Net increase in livestock (Livestock Statistics } \\
\text { Survey - KOSTAT); } \\
\text { Number of slaughtered livestock (Report on } \\
\text { Slaughtered Livestock); } \\
\text { Forestation area (Statistical Yearbook of } \\
\text { Forestry); } \\
\text { Fishery production (Fishery Production Survey - } \\
\text { KOSTAT). }\end{array}$ & Good \\
\hline $\begin{array}{l}\text { Mining and } \\
\text { quarrying }\end{array}$ & $\begin{array}{l}\text { Production value and major costs by item } \\
\text { (Mining and Manufacturing Survey - KOSTAT). }\end{array}$ & Good \\
\hline Manufacturing & $\begin{array}{l}\text { Production value and major costs by item } \\
\text { (Mining and Manufacturing Survey - KOSTAT); } \\
\text { Value added ratio (Financial Statement Analysis } \\
\text { - BOK). }\end{array}$ & Good \\
\hline $\begin{array}{l}\text { Electricity, gas and } \\
\text { water supply }\end{array}$ & $\begin{array}{l}\text { Quantity of electricity sold (Korea Electric Power } \\
\text { Corporation); } \\
\text { Income and expenses (Korea Electric Power } \\
\text { Corporation, Korea Gas Corporation, Korea } \\
\text { Water Resources Corporation). }\end{array}$ & Good \\
\hline
\end{tabular}




\begin{tabular}{|c|c|c|}
\hline Construction & $\begin{array}{l}\text { Output, value added for building construction and } \\
\text { engineering construction (Construction Survey - } \\
\text { KOSTAT); } \\
\text { Building construction by type (KOSTAT); } \\
\text { Financial Statement Analysis (Construction } \\
\text { Association of Korea, BOK). }\end{array}$ & Good \\
\hline $\begin{array}{l}\text { Wholesale and retail } \\
\text { trade }\end{array}$ & $\begin{array}{l}\text { Trade margins by commodity, value added ratio } \\
\text { (I-O Tables); } \\
\text { Output, distribution ratio and mark-up ratio } \\
\text { (Wholesale and Retail Trade Survey - KOSTAT, } \\
\text { Financial Statement Analysis - BOK); } \\
\text { External trade (KTS). }\end{array}$ & Good \\
\hline $\begin{array}{l}\text { Restaurants and } \\
\text { hotels }\end{array}$ & $\begin{array}{l}\text { Output (Service Industry Survey - KOSTAT); } \\
\text { Value added ratio (Financial Statement Analysis } \\
\text { - BOK). }\end{array}$ & Good \\
\hline $\begin{array}{l}\text { Transport and } \\
\text { storage }\end{array}$ & $\begin{array}{l}\text { Output and intermediate inputs (Transport Survey } \\
\text { - KOSTAT, and Financial statements Korea } \\
\text { Railroad Corporation (KORAIL)). }\end{array}$ & Good \\
\hline $\begin{array}{l}\text { Finance and } \\
\text { insurance }\end{array}$ & $\begin{array}{l}\text { Service charges, FISIM and intermediate inputs } \\
\text { (financial statements of financial institutions - } \\
\text { BOK). }\end{array}$ & Good \\
\hline $\begin{array}{l}\text { Real estate activities, } \\
\text { renting and leasing }\end{array}$ & $\begin{array}{l}\text { Number of households (Ministry of Public } \\
\text { Administration and Security); } \\
\text { Activity index (Service Industry Activity Index - } \\
\text { KOSTAT); } \\
\text { CPI - KOSTAT; PPI - BOK. }\end{array}$ & Good \\
\hline $\begin{array}{l}\text { Information and } \\
\text { communication }\end{array}$ & $\begin{array}{l}\text { Output and intermediate inputs (Yearbook of IT } \\
\text { Industry Statistics - Korea Association of } \\
\text { Information and Telecommunication); } \\
\text { Postal revenue and expenses (Korea Post). }\end{array}$ & $\begin{array}{l}\text { Reasonably } \\
\text { good }\end{array}$ \\
\hline $\begin{array}{l}\text { Public } \\
\text { administration, } \\
\text { defense and other } \\
\text { government services }\end{array}$ & $\begin{array}{l}\text { Central Government Budget and Central } \\
\text { Government Settlement Report; } \\
\text { Budget and Settlement Reports of Local } \\
\text { Governments; } \\
\text { Statistical Yearbook of National Tax. }\end{array}$ & Good \\
\hline $\begin{array}{l}\text { Business, education, } \\
\text { health and social } \\
\text { work, culture and } \\
\text { entertainment and } \\
\text { other services }\end{array}$ & $\begin{array}{l}\text { Output and value added ratio (Service Industry } \\
\text { Survey and National Tax Service); } \\
\text { Wide range of data sources used for various sub- } \\
\text { industries. }\end{array}$ & $\begin{array}{l}\text { Reasonably } \\
\text { good }\end{array}$ \\
\hline
\end{tabular}




\begin{tabular}{|c|c|c|}
\hline \multicolumn{3}{|c|}{ Expenditure Approach } \\
\hline $\begin{array}{l}\text { Expenditure } \\
\text { Category }\end{array}$ & Main Source & $\begin{array}{l}\text { Adequacy for } \\
\text { Annual } \\
\text { Estimates }\end{array}$ \\
\hline $\begin{array}{l}\text { Household final } \\
\text { consumption } \\
\text { expenditure }\end{array}$ & $\begin{array}{l}\text { Sales of goods and services to consumers (Census } \\
\text { of Service Industry, Household Income and } \\
\text { Expenditure Survey, Wholesale and Retail } \\
\text { Survey, Service Industry Survey, Transport } \\
\text { Survey - KOSTAT); } \\
\text { Purchases of grain, tobacco, electricity, gas, } \\
\text { water, heating (estimated separately using } \\
\text { appropriate source data); } \\
\text { Housing rents (Census of Population and } \\
\text { Housing); } \\
\text { Health (National Health Insurance Corporation) } \\
\text { Financial services (Financial statements of } \\
\text { financial institutions); } \\
\text { Education, entertainment and miscellaneous } \\
\text { services (estimated separately using appropriate } \\
\text { source data). }\end{array}$ & $\begin{array}{l}\text { Reasonably } \\
\text { good }\end{array}$ \\
\hline $\begin{array}{l}\text { Government final } \\
\text { consumption } \\
\text { expenditure }\end{array}$ & $\begin{array}{l}\text { Output (Obtained from production approach } \\
\text { estimates); } \\
\text { Receipts from sales (obtained from settlement } \\
\text { reports of general government sector); } \\
\text { Social security benefits in kind (= social security } \\
\text { benefits less social security benefits in cash) } \\
\text { (obtained from settlement reports for National } \\
\text { Health Insurance Corporation and Korea Labor } \\
\text { Welfare Corporation). }\end{array}$ & Good \\
\hline $\begin{array}{l}\text { GFCF - } \\
\text { Construction }\end{array}$ & $\begin{array}{l}\text { Estimated separately for building construction } \\
\text { and civil engineering and for private and general } \\
\text { government sectors; } \\
\text { Value of construction completed (Annual } \\
\text { Construction Work Survey); } \\
\text { Government sector investment (government } \\
\text { budget accounts); } \\
\text { Ownership transfer costs (Service Industry } \\
\text { Survey, National Tax Service); } \\
\text { Construction inventories of work in progress and } \\
\text { finished goods for dwellings (corporate balance } \\
\text { sheets from National Tax Service). }\end{array}$ & Good \\
\hline $\begin{array}{l}\text { GFCF - Machinery } \\
\text { and equipment }\end{array}$ & $\begin{array}{l}\text { Commodity flow method (using data on } \\
\text { shipments for } 500 \text { commodities from the Mining } \\
\text { and Manufacturing Survey and exports and } \\
\text { imports data for about } 2200 \text { commodities from } \\
\text { the Korea Customs Service); }\end{array}$ & $\begin{array}{l}\text { Reasonably } \\
\text { good }\end{array}$ \\
\hline
\end{tabular}




\begin{tabular}{|c|c|c|}
\hline & $\begin{array}{l}\text { Trade and transport margins (Wholesale and } \\
\text { Retail Survey - KOSTAT); } \\
\text { Transactions costs on second hand assets } \\
\text { (government tax revenues, etc). }\end{array}$ & \\
\hline $\begin{array}{l}\text { GFCF - Exploration } \\
\text { expenditure }\end{array}$ & $\begin{array}{l}\text { Exploration expenditure (Service Industry Survey } \\
\text { - KOSTAT; } \\
\text { Customs clearance for exports and imports - } \\
\text { Korea Customs Service).. }\end{array}$ & $\begin{array}{l}\text { Reasonably } \\
\text { good }\end{array}$ \\
\hline GFCF - Software & $\begin{array}{l}\text { Software expenditure (Service Industry Survey - } \\
\text { KOSTAT; } \\
\text { Yearbook of IT Industry Statistics - Korea } \\
\text { Association of Information and } \\
\text { Telecommunication; } \\
\text { Customs clearance for exports and imports - } \\
\text { Korea Customs Service). }\end{array}$ & $\begin{array}{l}\text { Reasonably } \\
\text { good }\end{array}$ \\
\hline $\begin{array}{l}\text { Changes in } \\
\text { inventories }\end{array}$ & $\begin{array}{l}\text { Changes in book value of inventories less } \\
\text { inventory valuation adjustment (Mining and } \\
\text { Manufacturing Survey, Census of Service } \\
\text { Industry, Construction Work Survey - KOSTAT; } \\
\text { Financial statements of corporations - National } \\
\text { Tax Service); } \\
\text { Volume data used for some commodities (e.g., } \\
\text { Petroleum Supply-and-Demand Statistics, } \\
\text { Livestock Statistics). }\end{array}$ & $\begin{array}{l}\text { Reasonably } \\
\text { good }\end{array}$ \\
\hline $\begin{array}{l}\text { Exports of goods and } \\
\text { services }\end{array}$ & $\begin{array}{l}\text { BOP data adjusted to convert from US dollars to } \\
\text { Korean won, and to adjust ship exports to a value } \\
\text { of construction completed basis. }\end{array}$ & Good \\
\hline $\begin{array}{l}\text { Imports of goods and } \\
\text { services }\end{array}$ & $\begin{array}{l}\text { BOP data adjusted to convert from US dollars to } \\
\text { Korean won. }\end{array}$ & Good \\
\hline
\end{tabular}

Text Table 2: Main Sources for the Quarterly Accounts

\begin{tabular}{|l|l|l|}
\hline \multicolumn{2}{|c|}{ Production Approach } \\
\hline $\begin{array}{l}\text { Korean Standard } \\
\text { Classification }\end{array}$ & Main Source & $\begin{array}{l}\text { Adequacy for } \\
\text { Quarterly } \\
\text { Estimates }\end{array}$ \\
\hline $\begin{array}{l}\text { Agriculture, forestry } \\
\text { and fishing }\end{array}$ & $\begin{array}{l}\text { Cultivation area (Crop Production Survey - } \\
\text { KOSTAT); } \\
\text { Net increase in livestock numbers (Livestock } \\
\text { Statistics Survey - KOSTAT); } \\
\text { Livestock slaughtered (National Veterinary } \\
\text { Research and Quarantine Service); } \\
\text { Fishery production (Fishery Production Survey - } \\
\text { KOSTAT). }\end{array}$ & Adequate \\
\hline $\begin{array}{l}\text { Mining and } \\
\text { quarrying }\end{array}$ & $\begin{array}{l}\text { Production quantities and prices from a range of } \\
\text { sources including IPI from KOSTAT and PPI, }\end{array}$ & $\begin{array}{l}\text { Reasonably } \\
\text { good }\end{array}$ \\
\hline
\end{tabular}




\begin{tabular}{|c|c|c|}
\hline & and XPI from BOK. & \\
\hline Manufacturing & $\begin{array}{l}\text { Production, shipments, inventory indexes by item } \\
\text { (IPI - KOSTAT); } \\
\text { Value added ratio (Financial Statement Analysis } \\
\text { - BOK). }\end{array}$ & Good \\
\hline $\begin{array}{l}\text { Electricity, gas and } \\
\text { water supply }\end{array}$ & $\begin{array}{l}\text { Monthly quantity of electricity sold, values of } \\
\text { sales (Monthly Report on Major Electric Power } \\
\text { Statistics - Korea Electric Power Corporation); } \\
\text { Quarterly quantities and values for gas (Korea } \\
\text { Gas Corporation); } \\
\text { Quarterly quantities and values for water } \\
\text { (provincial governments); } \\
\text { Income and expenses (Korea Electric Power } \\
\text { Corporation, Korea Gas Corporation, Korea } \\
\text { Water Resources Corporation). }\end{array}$ & Good \\
\hline Construction & $\begin{array}{l}\text { Value of construction completed (monthly - } \\
\text { KOSTAT); } \\
\text { Area of construction started (monthly); } \\
\text { Output of civil engineering for central and local } \\
\text { government (monthly); } \\
\text { Output of private civil engineering (quarterly). }\end{array}$ & $\begin{array}{l}\text { Reasonably } \\
\text { good }\end{array}$ \\
\hline $\begin{array}{l}\text { Wholesale and retail } \\
\text { trade }\end{array}$ & $\begin{array}{l}\text { Service Industry Activity Index (quarterly - } \\
\text { KOSTAT) }\end{array}$ & $\begin{array}{l}\text { Reasonably } \\
\text { good }\end{array}$ \\
\hline $\begin{array}{l}\text { Restaurants and } \\
\text { hotels }\end{array}$ & $\begin{array}{l}\text { Service Industry Activity Index (quarterly - } \\
\text { KOSTAT). }\end{array}$ & Good \\
\hline $\begin{array}{l}\text { Transport and } \\
\text { storage }\end{array}$ & $\begin{array}{l}\text { Revenue growth (sample survey - BOK, Service } \\
\text { Industry Activity Index - KOSTAT). }\end{array}$ & $\begin{array}{l}\text { Reasonably } \\
\text { good }\end{array}$ \\
\hline $\begin{array}{l}\text { Finance and } \\
\text { insurance }\end{array}$ & $\begin{array}{l}\text { Service charges, FISIM and intermediate inputs } \\
\text { (financial statements of financial institutions - } \\
\text { BOK). }\end{array}$ & Good \\
\hline $\begin{array}{l}\text { Real estate activities, } \\
\text { renting and leasing }\end{array}$ & $\begin{array}{l}\text { Number of households (Ministry of Public } \\
\text { Administration and Security); } \\
\text { Activity index (Service Industry Activity Index - } \\
\text { KOSTAT); } \\
\text { CPI - KOSTAT; PPI - BOK. }\end{array}$ & Good \\
\hline $\begin{array}{l}\text { Information and } \\
\text { communication }\end{array}$ & $\begin{array}{l}\text { Output (sample survey - BOK, Service Industry } \\
\text { Activity Index - KOSTAT, Financial statements } \\
\text { of enterprises). }\end{array}$ & $\begin{array}{l}\text { Reasonably } \\
\text { good }\end{array}$ \\
\hline $\begin{array}{l}\text { Public } \\
\text { administration, } \\
\text { defense and other } \\
\text { government services }\end{array}$ & $\begin{array}{l}\text { Execution results by item (Monthly - MOSF) } \\
\text { Budget and expenditure by item (Monthly - } \\
\text { MOPAS, relevant educational offices). }\end{array}$ & $\begin{array}{l}\text { Reasonably } \\
\text { good }\end{array}$ \\
\hline
\end{tabular}




\begin{tabular}{|c|c|c|}
\hline $\begin{array}{l}\text { Business, education, } \\
\text { health and social } \\
\text { work, culture and } \\
\text { entertainment and } \\
\text { other services }\end{array}$ & $\begin{array}{l}\text { Sales for some sub-industries (Service Industry } \\
\text { Activity Index - KOSTAT); } \\
\text { Output growth (Quarterly Service Industry } \\
\text { Survey - BOK); } \\
\text { Various quarterly volume or value indicators for } \\
\text { sub-industries. }\end{array}$ & $\begin{array}{l}\text { Reasonably } \\
\text { good }\end{array}$ \\
\hline \multicolumn{3}{|c|}{ Expenditure Approach } \\
\hline $\begin{array}{l}\text { Expenditure } \\
\text { Category }\end{array}$ & Main Source & $\begin{array}{l}\text { Adequacy for } \\
\text { Quarterly } \\
\text { Estimates }\end{array}$ \\
\hline $\begin{array}{l}\text { Household final } \\
\text { consumption } \\
\text { expenditure }\end{array}$ & $\begin{array}{l}\text { Retail sales by type of business and } 13 \text { groups of } \\
\text { goods (Retail Sales Statistics, monthly - } \\
\text { KOSTAT); } \\
\text { Value and volume of sales (Service Industry } \\
\text { Activity Index, monthly - KOSTAT); } \\
\text { HIES (Quarterly - KOSTAT). }\end{array}$ & $\begin{array}{l}\text { Reasonably } \\
\text { good }\end{array}$ \\
\hline $\begin{array}{l}\text { Government final } \\
\text { consumption } \\
\text { expenditure }\end{array}$ & $\begin{array}{l}\text { Output (Obtained from production approach } \\
\text { estimates); } \\
\text { Receipts from sales (derived from estimates of } \\
\text { output); } \\
\text { Social security benefits in kind (based on data } \\
\text { from Health Insurance Review Agency, National } \\
\text { Health Insurance Corp. and the estimated growth } \\
\text { rate in re-employment education). }\end{array}$ & $\begin{array}{l}\text { Reasonably } \\
\text { good }\end{array}$ \\
\hline $\begin{array}{l}\text { GFCF - } \\
\text { Construction }\end{array}$ & $\begin{array}{l}\text { Value of construction completed (Monthly } \\
\text { Survey of Construction Activity - KOSTAT); } \\
\text { Area of building authorized and commenced } \\
\text { (Monthly - Ministry of Land, Transport and } \\
\text { Maritime Affairs). }\end{array}$ & $\begin{array}{l}\text { Reasonably } \\
\text { good }\end{array}$ \\
\hline $\begin{array}{l}\text { GFCF - Machinery } \\
\text { and equipment }\end{array}$ & $\begin{array}{l}\text { Volume of shipments (Monthly Survey of Mining } \\
\text { and Manufacturing); } \\
\text { Volume and value of exports and imports } \\
\text { (Customs clearances for exports and imports). }\end{array}$ & $\begin{array}{l}\text { Reasonably } \\
\text { good }\end{array}$ \\
\hline $\begin{array}{l}\text { GFCF - Exploration } \\
\text { expenditure }\end{array}$ & $\begin{array}{l}\text { Exploration expenditure (Service Industry } \\
\text { Activity Index - KOSTAT; } \\
\text { Customs clearance for exports and imports - } \\
\text { Korea Customs Service). }\end{array}$ & $\begin{array}{l}\text { Reasonably } \\
\text { good }\end{array}$ \\
\hline GFCF - Software & $\begin{array}{l}\text { Software expenditure (Service Industry Activity } \\
\text { Index - KOSTAT; } \\
\text { IT Industry Statistics - Korea Association of } \\
\text { Information and Telecommunication; } \\
\text { Customs clearance for exports and imports - } \\
\text { Korea Customs Service). }\end{array}$ & $\begin{array}{l}\text { Reasonably } \\
\text { good }\end{array}$ \\
\hline $\begin{array}{l}\text { Changes in } \\
\text { inventories }\end{array}$ & $\begin{array}{l}\text { Inventories at the end of the quarter by industries } \\
\text { and types (Financial Statements of Corporations); } \\
\text { Inventory index of finished goods by item }\end{array}$ & Adequate \\
\hline
\end{tabular}




\begin{tabular}{|l|l|l|}
\hline & (Producer Product Inventory Index - KOSTAT) & \\
& Livestock numbers (quarterly - Livestock \\
Statistics); & Crude oil and petroleum products (Petroleum \\
& $\begin{array}{l}\text { Supply and Demand Statistics - Korea National } \\
\text { Oil Corporation); } \\
\text { Unsold Housing Statistics (Ministry of Land, } \\
\text { Transportation and Maritime Affairs). }\end{array}$ & \\
\hline $\begin{array}{l}\text { Exports of goods and } \\
\text { services }\end{array}$ & $\begin{array}{l}\text { BOP data adjusted to convert from US dollars to } \\
\text { Korean won, and to adjust ship exports to a value } \\
\text { of construction completed basis. }\end{array}$ & Good \\
\hline $\begin{array}{l}\text { Imports of goods and } \\
\text { services }\end{array}$ & $\begin{array}{l}\text { BOP data adjusted to convert from \$US to } \\
\text { Korean won. }\end{array}$ & Good \\
\hline
\end{tabular}

3.1.2 Source data reasonably approximate the definitions, scope, classifications, valuation, and time of recording required

Most source data provided by KOSTAT meet the requirements of the national accounts. KOSTAT consults with the BOK to ensure its surveys satisfy the requirements of the national accounts as far as possible. It also consults with the BOK in advance when planning modifications to questionnaires. However, some KOSTAT surveys do not provide the complete information required. The monthly establishment survey data for mining and manufacturing, which are used to construct the IPI, are therefore used by the BOK to estimate quarterly quantities by product. KOSTAT's annual survey data for manufacturing are used for the estimation of gross output, but annual and quarterly value added is estimated by applying the value added ratio derived from the annual or quarterly Financial Statement Survey to gross output, since the value added from the KOSTAT's annual survey is calculated by subtracting production costs that are available at the establishment level (rather than the enterprise level) from gross output.

Some administrative data from government agencies such as the KCS, the KTS, and the MOSF that use different definitions of items, or a different time of recording, need to be adjusted to meet to national accounts requirements.

The coverage of total economic activities (in terms of value added) by all data sources is higher for final than for preliminary versions of the accounts, at 90 percent of economic activities. Coverage is also good for activities (in terms of value added) within the most important industrial groups (e.g., ISIC one-digit level).

\subsubsection{Source data are timely}

All the source data required to produce the GDP estimates are supplied on a timely basis. 


\subsection{Assessment of source data}

3.2.1 Source data-including censuses, sample surveys, and administrative records-are routinely assessed, e.g., for coverage, sample error, response error, and nonsampling error; the results of the assessments are monitored and made available to guide statistical processes

Financial statements from the finance and insurance industry are provided to the BOK in conjunction with its regulatory functions. Surveys conducted by the BOK for other sectors generally do not have sample errors because they are conducted for a limited number of major companies and industry associations. The BOK assesses the adequacy of its surveys by confirming outliers with respondents, and by undertaking time series analysis and cross-sectional analysis.

Information is available from KOSTAT on sampling errors, non-sampling errors, and coverage for its censuses and surveys. If data from KOSTAT appear to contain unusual results, these are queried with KOSTAT.

The BOK always checks the accuracy of source data such as government finance statistics, BOP statistics, merchandise trade statistics, price and volume statistics, and other source data whenever they are being used for compiling the national accounts.

\subsection{Statistical techniques}

\subsubsection{Data compilation employs sound statistical techniques to deal with data sources}

The BOK runs a number of relatively small-scale special collections for use in compiling the national accounts. It minimizes processing errors through the use of error checking functions available within the computer software used to tabulate survey results and by staff using mutual checking procedures. Adjustments for outliers and non-response are made after confirmation with to the data supplier and comparison with other sources for similar data, respectively.

KOSTAT provides many important data sources for the national accounts. Surveys and censuses conducted by KOSTAT employ sound statistical techniques. Good statistical practices are followed, including testing of modified questionnaires before use; conducting pilot tests for major collections; and three stage editing procedures-enumerator reviews of data provided; input edits to identify outliers and invalid data; and reviews of data by head office staff. Very high response rates are achieved to surveys and censuses-around 99 percent. In sample surveys non-respondents are replaced by comparable units, but there are only a very small number of such cases in all surveys. Unusual data responses are checked with respondents by phone, and for large companies comparisons are made with data available on a website that contains financial statements for all large companies that are required to submit their financial statements on a regular basis. 


\subsubsection{Other statistical procedures (e.g., data adjustments and transformations, and statistical analysis) employ sound statistical techniques}

Non-observed activities including informal, hidden and illegal activities are not fully included in the national accounts because of insufficient source data. Non-observed activities are not separately identified in the accounts, but some elements of the non-observed economy are captured in the accounts given the methods of estimation used. For example, small traders in the retail sector that are not within the scope of KOSTAT surveys may be included in taxation statistics from the KTS. The use of credit cards and charge cards is widespread in Korea even for small retail outlets. The BOK also makes efforts to capture more non-observed activities in the national accounts by expanding special collections from service industries and by developing new source data. The BOK does not consider that the non-observed economy is a major issue.

\section{Production approach procedures}

The national accounts compilation systems employ four levels of industry dissection; highest breakdown (16 industry sectors), middle breakdown (27 industry sectors), lower breakdown (81 industry sectors), and basic breakdown (399 industry sectors). Output estimates are compiled at the basic breakdown level corresponding to the four-digit level of ISIC Rev.4. Intermediate consumption estimates are compiled in detail at the lower breakdown broadly corresponding to the two-digit level of ISIC Rev.4.

In addition to the five-yearly benchmark I-O tables (the latest being for 2005), the BOK is now producing annual I-O tables every year from 2006. The final national accounts estimates for value added by industry for 2006 and 2007 have been reconciled with the corresponding estimates in the annual I-O tables. Consequently, fixed ratios more than five years old are not used in estimating nominal value added.

The output of owner-occupied dwellings is valued at the estimated rentals that tenants would pay for similar accommodation. When calculating actual rents and imputed rents for owner occupiers for the benchmark year 2005, the data from the Census of Population and Housing are cross-classified by 16 major cities and provinces, by type of dwelling and by number of rooms.

Work in progress is estimated for growing crops, standing timber, livestock reared for food, large construction projects and ships. However, no estimates are included for fish stocks owing to the lack of suitable data.

The PIM is used as the basis for estimating consumption of fixed capital in current price terms for general government. However, reported depreciation data are used for consumption of fixed capital in other sectors. Developmental work is currently being undertaken by the National Balance Sheet Team in the BOK to develop capital stock estimates (and also estimates for consumption of fixed capital). 
General government data such as taxes, subsidies, revenue, and expenditure, which are initially compiled on a cash basis, are adjusted to an accrual basis within the BOK. The estimates of the output of buildings and ships, which require a long period to be produced, are based on the value of construction undertaken in the period.

Output is deflated at the basic breakdown level (399 industries), which corresponds to the four-digit level of ISIC, while intermediate consumption is deflated in detail at the 81 industry level, which corresponds to the two-digit level of ISIC. For estimating final annual GDP, the double indicator method is used to obtain real value added in most industries except for public administration and defense and the general government components of other industries. Elements of the PPI are generally used as deflators for output and intermediate consumption, while synthesized indices, based on the input structures from the annual I-O tables, are derived for use in construction, finance, and insurance.

The real output of government service industries, such as public administration and defense, is measured as the sum of real intermediate consumption and real value added, based on the cost of production approach. The intermediate input deflator for government services is obtained as a weighted average of CPI and PPI component indices, and is used to calculate real intermediate input of government services. Real value added of government services is derived by adding volume estimates for compensation of employees (based on the number of public officials), consumption of fixed capital (deflated using an index that is calculated using the producer price index and other asset deflators), and other taxes on production (deflated using an intermediate consumption deflator).

For estimating quarterly GDP, the double deflation method is not used in mining and quarrying, manufacturing, wholesale and retail trade, restaurants and hotels, and private sector service industries because of insufficient source data on intermediate inputs. In these industries, real output is calculated by extrapolating volume data or deflating nominal data.

Volume measures of taxes/subsidies on products are estimated by applying annual chain-linking indices computed by using the tax ratio of the previous year. The output volume of trade margins is estimated as the difference between real sales and real cost of sales deflated by relevant price indices such as PPI, CPI, and IPI.

GDP volume change is measured using annual chain Laspeyres indices. For quarterly GDP estimation, the annual overlap method, which uses average price data from the previous year as the weight with the linking factors derived from the annual data, is used.

\section{Expenditure approach procedures}

Household final consumption expenditure, gross fixed capital formation, and changes in inventories are derived independently with no major aggregate or component being derived as a balancing item. However, investment in machinery and equipment is based on a modified commodity flow method using data on the value of shipments rather than production values. 
Household final consumption expenditure is compiled using 160 basic headings from COICOP. Government final consumption expenditure is compiled at the one-digit level of COFOG. Both gross-fixed capital formation and changes in inventories are compiled by industry and by type of asset.

When estimating the expenditure components of GDP, fixed ratios more than five years old are not used, because the expenditure components are now estimated independently using source data appropriate to each aggregate.

Appropriate techniques are applied to address the following specific issues of GDP compilation, with one exception, that works of art are not included in valuables because of inadequate data:

- $\quad$ Government final expenditure excludes incidental sales.

- $\quad$ Expenses of residents abroad are included in household final consumption expenditure and in imports.

- $\quad$ Expenses of nonresidents in the economy are excluded from household final consumption expenditure and included in exports.

- $\quad$ Expenditures on items that are considered stores of wealth (such as jewelry, works of art) are included in the estimates of valuables.

All the expenditure components including final consumption expenditure, gross fixed capital formation, changes in inventories, imports and exports are deflated with relevant price indices such as the PPI, CPI, XPI, and MPI at the most detailed level available.

The household consumption implicit deflator is generally consistent with the CPI because household consumption expenditure is deflated at a detailed level, mainly using component indices from the CPI.

Real government final consumption expenditure is derived as the sum of real intermediate consumption and real value added (comprising compensation of employees, consumption of fixed capital, and other taxes on production). Real intermediate consumption is estimated by deflating nominal intermediate consumption with a weighted index derived from components of the PPI and the CPI. Compensation of employees at constant prices is derived using data on the number of employees. Real consumption of fixed capital and real other taxes on production are derived by using relevant price deflators.

Appropriate methods are used to derive volume measures for changes in inventories.

The BOK uses the Denton technique for ensuring that seasonally adjusted estimates for the four quarters of a year add to the annual estimate. However, the Denton method is not applied in order to ensure that the original quarterly series add to the annual benchmark. Instead any differences are simply prorated across the four quarters. 
It was observed that quarterly estimates for consumption of fixed capital for general government are being derived by dividing the annual estimates by four. A better approach would be to use a trending formula to convert the annual series for consumption of fixed capital for general government into a quarterly series. Appropriate methods for doing so are outlined in Section VII (Mechanical Projections) of the IMF publication Quarterly National Accounts Manual: Concepts, Data Sources, and Compilation.

Estimates of quarterly GDP are initially derived from unadjusted source data and are then seasonally adjusted. Both the original series and seasonally adjusted series are published. Seasonally adjusted quarterly GDP estimates are produced using the BOK-X12-ARIMA program, a Korean version of the U.S. Census Bureau's X-12-ARIMA. The BOK-12ARIMA program reflects statistical characteristics that are relevant to Korea, such as changes in official holidays that are based on the lunar calendar. A seasonal reanalysis is conducted annually, with forward factors being calculated for the year ahead.

\subsection{Assessment and validation of intermediate data and statistical outputs}

\subsubsection{Intermediate results are validated against other information, where applicable}

Intermediate results compiled from the main sources are checked against other independent data sources such as financial statements of registered enterprises, employment statistics, and tax data from the KTS.

\subsubsection{Statistical discrepancies in intermediate data are assessed and investigated}

The discrepancies between intermediate results and other independent source data are assessed whenever national accounts are compiled. If necessary, appropriate adjustments are made to remove the discrepancies. For instance, if increases in productivity and enterprises' efforts to cut costs are not reflected in the main source data of the national accounts, the BOK undertakes additional data collections from the relevant enterprises to estimate the necessary adjustments to the original source data.

\subsubsection{Statistical discrepancies and other potential indicators of problems in statistical outputs are investigated}

Differences between GDP compiled from the production and expenditure approaches are analyzed and, where appropriate, adjustments are made. The published GDP estimates are obtained using the production approach, since source data for value added by industry are more abundant and considered to be more reliable than those for the expenditure components. A statistical discrepancy between GDP by production activities and GDP by expenditure components is shown explicitly on the expenditure side, as a SUT framework is not used. The statistical discrepancy has not exceeded 1 percent of GDP on either an annual or a quarterly basis over the last 10 years. 
In Korea, there are no unofficial estimates against which the official GDP estimates can be validated. Some research institutions forecast the growth rates of GDP and expenditure components, but these figures are not considered reliable.

It was observed that the GDP growth rate based on a fixed base year method might have been biased due to the rapid growth of information and communication technology since the 1990s. In order to remove this bias, the annual chain-linking method was introduced in March 2009 at the time of rebasing from 2000 to 2005.

\subsection{Revision studies}

\subsubsection{Studies and analyses of revisions are carried out routinely and used internally to inform statistical processes (see also 4.3.3)}

The BOK analyzes the differences between the initial estimates and the revised estimates when preliminary quarterly GDP and final annual GDP are compiled. Most of the differences are caused by replacing forecasts by actual data, and by discrepancies between quarterly source data and annual source data. Studies of long-term trends in the revision pattern are conducted every five years at the time of rebasing. The revisions arising from rebasing are mostly explained by changing the reference year for price and volume indices, changing source data, changing estimation methods, and the appearance of new commodities.

A study was undertaken in 2006 concerning revisions between preliminary and final quarterly estimates of GDP covering the period from the third quarter 1999 to the fourth quarter 2004. The research paper entitled Case Study on Revisions between Preliminary and Final Quarterly GDP is available on the BOK's website. Seasonally adjusted estimates were first published in Korea's quarterly national accounts in 1999. This type of study should be repeated periodically to provide information concerning the size of revisions and any biases in the revisions to GDP and its major components.

\section{Serviceability}

\subsection{Periodicity and timeliness}

\subsubsection{Periodicity follows dissemination standards}

Korea meets the Special Data Dissemination Standard (SDDS) with respect to the periodicity of the GDP estimates. Estimates of GDP are published quarterly at both current and constant prices.

\subsubsection{Timeliness follows dissemination standards}

Korea exceeds the SDDS requirements with respect to timeliness. The advance quarterly GDP estimates are disseminated within four weeks after the end of the quarter concerned, while the preliminary quarterly GDP estimates are released within 10 weeks after the end of 
the quarter. The preliminary annual GDP estimates are disseminated within three months after the end of the year, with the final annual figures being released one year later.

\subsection{Consistency}

\subsubsection{Statistics are consistent within the dataset}

The official estimates of GDP for Korea are derived using the production approach. A statistical discrepancy is included to reconcile the estimates of GDP derived using the expenditure approach with those from the production approach. In practice the statistical discrepancy has been relatively small and reasonably consistent over time.

GDP estimates at current prices, those at constant prices, and the implicit deflators are consistent within the "value $=$ volume $\times$ price" framework.

The concepts, definitions, and classifications used for the quarterly and annual GDP estimates are identical. The sources and methods used to compile the quarterly and annual estimates of GDP are in some cases basically the same. However, in other cases indicators are used for the quarterly estimates leading to revisions when the annual data become available. These differences are prorated over the quarters, but it would be more appropriate to use the Denton technique to ensure that the movements between the fourth quarter of one year and the first quarter of the next year are not distorted.

\subsubsection{Statistics are consistent or reconcilable over a reasonable period of time}

Consistent annual and quarterly time series are maintained from 1970 in accordance with the $1993 S N A$. Data are also available for 1953 to 1969 based on the 1953 SNA, with the constant price estimates using 1975 as the base year, they are based on the 1953 SNA because there were insufficient source data at the time of transition from the 1953 SNA to the 1968 SNA. Consequently, time series data currently are revised only back to 1970 when the methodology or the reference year is changed; the discontinuities in the time series between 1969 and 1970 are explained in the relevant publications, metadata, and press releases.

In March 2009, chain volume measures were introduced and a new reference year (2005) was adopted. The initial release provided estimates for the period from 2000 forward, with the full time series from 1970 released in December.

\subsubsection{Statistics are consistent or reconcilable with those obtained through other data sources and/or statistical frameworks}

The BOP data are used directly in the national accounts after being converted to Korean won, with an adjustment to measure exports of ships on a work done basis rather than recording the full value of the ship at the time of delivery to a non-resident buyer. On some occasions the national accounts may not reflect revisions to earlier quarters' BOP data until the next annual revision of the national accounts. 
Government finance statistics are used directly in the national accounts after making appropriate adjustments for consumption of fixed capital and FISIM, and to convert various flows from a cash to an accrual basis.

Data from the IPI produced by KOSTAT are used in compiling the accounts, but, when necessary, appropriate adjustments are made based on other detailed data sources and special analyses.

\subsection{Revision policy and practice}

\subsubsection{Revisions follow a regular and transparent schedule}

The revision cycle of the national accounts follows a regular and transparent schedule, determined on the basis of the availability of source data and the timing of revisions to related datasets. The revisions cycle is explained in the national accounts publications and press releases, and explanations for revisions are given in the text accompanying the statistical tables. Special revisions, due to the discovery of new source data or the correction of significant errors, have never been necessary.

There can be revisions between the advance quarterly and the preliminary quarterly publications. However, no revisions are made to the preliminary quarterly estimates for the first three quarters of the year. At the end of March each year preliminary annual estimates are released for the latest year and final annual estimates for the previous year. At that time revisions are made to the quarterly estimates for the original data for the last two years, and seasonally adjusted estimates are revised following the annual seasonal reanalysis. Every five years a major revision is undertaken using data from the benchmark I-O tables, moving the reference period for the volume estimates forward five years to coincide with the latest I-O benchmark year.

\subsubsection{Preliminary and/or revised data are clearly identified}

The advance and preliminary estimates are distinguished from final estimates by putting the letter ' $p$ ' next to the date. In general, quarterly estimates of the previous year and the current year are preliminary. Similarly, the letter ' $r$ ' is used to indicate revised estimates.

\subsubsection{Studies and analyses of revisions are made public (see also 3.5.1)}

Differences between the preliminary and advance data, and differences between the final and preliminary data, are explained to users at the time of dissemination. An analysis of the revisions arising from the annual seasonal reanalysis is included in the quarterly publication. Detailed analyses of revisions for major aggregates are published every five years at the time of rebasing. 


\section{Accessibility}

\subsection{Data accessibility}

\subsubsection{Statistics are presented in a way that facilitates proper interpretation and meaningful comparisons (layout and clarity of text, tables, and charts)}

The BOK provides various tables, charts, and analytical reports in the publications and press releases. The quarterly national accounts include value added data for 27 industries and data for 25 expenditure components of GDP in current prices and chained average 2005 prices for both original and seasonally adjusted series. In the quarterly press release, time series for the latest three years are included, as well as annual estimates for the latest eight years, and, for major indicators, the full annual time series. In the quarterly hard copy publication quarterly data are recorded for at least eight years.

\subsubsection{Dissemination media and format are adequate}

Contributions to growth, and major aggregates that the media are particularly interested in, are tabulated in the form of reference tables in the national accounts press release. More detailed statistics and past time series data that are not included in publications or press releases are provided through ECOS, from which users can download time series from a number of statistical fields and present data in charts and tables.

However, the accessibility to ECOS on which the relevant data and metadata are stored at the moment is somewhat problematic. Access to the ECOS system when using Internet Explorer involves the use of the so called "Active X" component that is intended to increase the speed of access to the site. Upon seeking to access ECOS, users are asked to download a dedicated locally-provided software program. While this software may be cutting-edge in terms of accessing and manipulating data, the "Active X" component on the Internet Explorer apparently prevents it crossing the firewalls that protect users, or leads to security warnings before the software can be downloaded. The BOK is aware of this issue, and is working on addressing it. The BOK estimates that the problem will be resolved by 2012, when there will be state-of-the-art browser-free access. In the meantime, however, international users without direct access to the $\mathrm{BOK}$ are restricted to obtaining data and metadata from print publications or by going through commercial vendors.

\subsubsection{Statistics are released on a pre-announced schedule}

The BOK provides an advance release schedule for the national accounts statistics for the forthcoming year on a "no-later-than" basis. The exact release date is advised one week prior to the dissemination date, and the BOK releases the national accounts statistics on the preannounced date. This system will be continued for the advance quarterly national accounts releases. However, since the end of 2009 the precise release dates are being specified for the preliminary quarterly national accounts releases one year in advance. 


\subsubsection{Statistics are made available to all users at the same time}

The BOK informs users of the contents of national accounts releases and of procedures to access them through publications, press releases, and the internet. The national accounts statistics are released to all users simultaneously exactly at the pre-announced time.

\subsubsection{Statistics not routinely disseminated are made available upon request}

Upon request, the BOK provides users with more detailed statistics free of charge, provided that they are non-confidential. For example, value added data are released for 27 industry categories, but more detailed data are available for 81 industries on request. Requests for unpublished statistics, and enquiries about the statistics, can be made by mail, email, or telephone. The availability of this service is publicized in the publications and on the BOK's website.

\subsection{Metadata accessibility}

5.2.1 Documentation on concepts, scope, classifications, basis of recording, data sources, and statistical techniques is available, and differences from internationally accepted standards, guidelines, or good practices are annotated

The Korean System of National Accounts, Concepts, Sources and Methods was published in 2005 in Korean only. The BOK plans to update this publication in 2010 and to publish it in both English and Korean. Quarterly National Accounts in Korea was published in 2006 in Korean and in 2007 in English. It is hoped to update this publication in 2011 (although this timing is not yet definite). These publications provide detailed information on data sources and methods of compilation. The updates are necessary, in particular in order to reflect changes to sources and methods introduced in conjunction with the rebasing from 2000 to 2005, the results of which were published in March 2009.

The BOK provides metadata in English and Korean containing detailed information on national accounts through ECOS. These metadata are updated periodically as required. SDDS metadata for the IMF are updated annually via KOSTAT, since KOSTAT is the Korean coordinator for maintaining the IMF's Dissemination Standards Bulletin Board (DSBB). Updated SDDS metadata for the national accounts for this year were provided to KOSTAT in October 2009.

\subsubsection{Levels of detail are adapted to the needs of the intended audience}

General use information about national accounts statistics is provided in press releases and is also publicized in Understanding and Use of Economic Statistics (released in March 2009). More specialized information such as research papers, periodicals, and publications are available from ECOS. 


\subsection{Assistance to users}

\subsubsection{Contact points for each subject field are publicized}

All requests from users must be answered immediately according to the Manual on Civil Petition. Contact information is provided in publications, and on the BOK's website. The BOK operates an economic statistics information center which uses an automated response service to provide better service to users. User requests are monitored daily and are answered promptly.

5.3.2 Catalogs of publications, documents, and other services, including information on any charges, are widely available

A catalog of statistical publications is provided in Understandable Explanation of Economic Indicators and Understanding and Use of Economic Statistics. Users can download press releases, statistical periodicals, and metadata on sources and methods from the BOK's website and ECOS free of charge. 
Table 1. Data Quality Assessment Framework (July 2003): Summary of Results for National Accounts

(Compiling Agency: Bank of Korea)

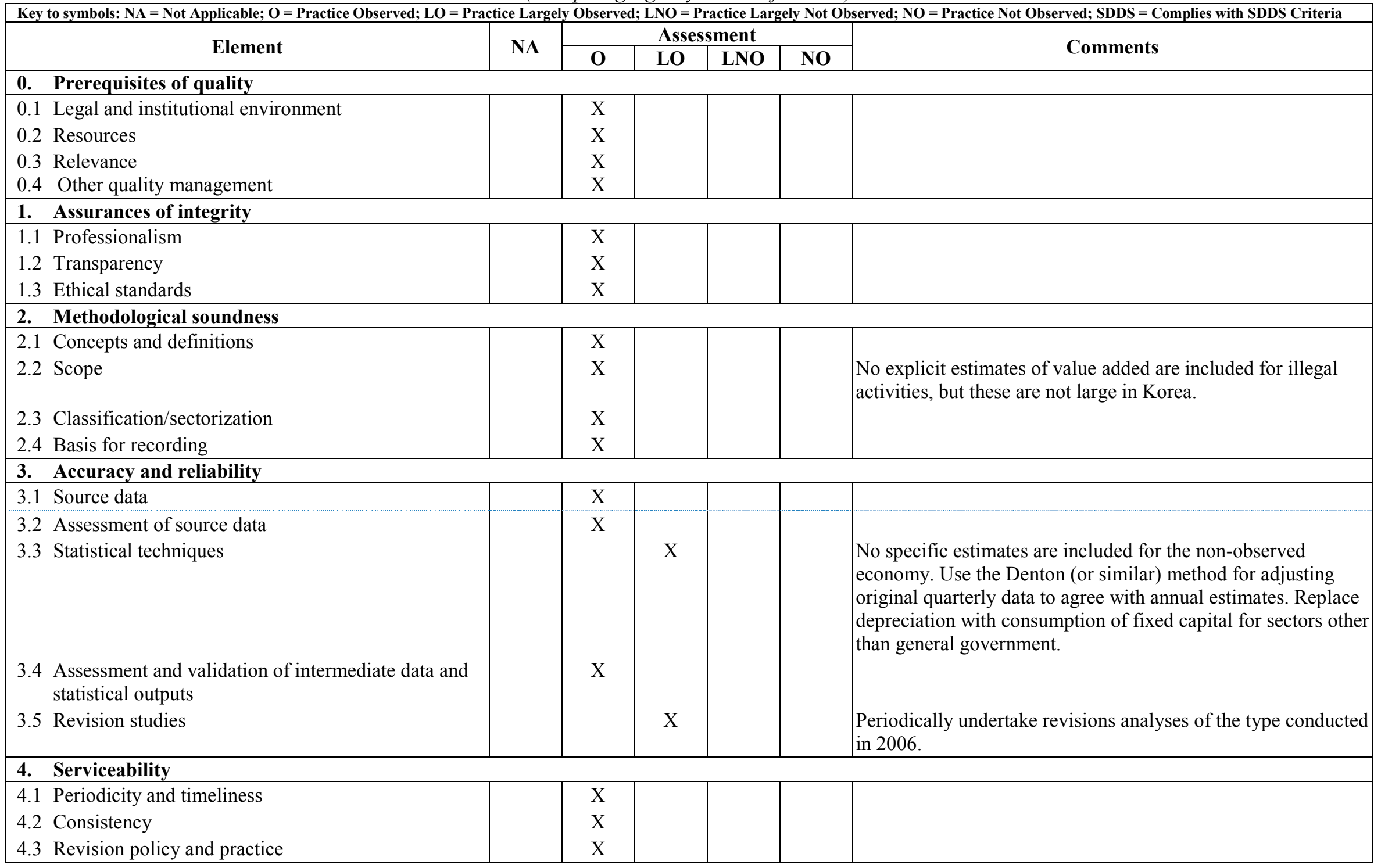


Table 1. Data Quality Assessment Framework (July 2003): Summary of Results for National Accounts

(Compiling Agency: Bank of Korea)

\begin{tabular}{|c|c|c|c|c|c|c|}
\hline \multirow{2}{*}{ Element } & \multirow{2}{*}{ NA } & \multicolumn{4}{|c|}{ Assessment } & \multirow{2}{*}{ Comments } \\
\hline & & $\mathbf{O}$ & LO & LNO & NO & \\
\hline \multicolumn{7}{|l|}{$\begin{array}{ll}\text { 5. } & \text { Accessibility }\end{array}$} \\
\hline 5.1 Data accessibility & & & $\mathrm{X}$ & & & $\begin{array}{l}\text { Access to the data posted on the BOK's online database } \\
\text { (ECOS) requires the installation of software that may create } \\
\text { computer security concerns particularly for non-Korean users. }\end{array}$ \\
\hline 5.2 Metadata accessibility & & $\mathrm{X}$ & & & & \\
\hline 5.3 Assistance to users & & $\mathrm{X}$ & & & & \\
\hline
\end{tabular}




\section{Recommendations}

- Develop estimates for gross fixed capital formation for entertainment, literary, or artistic originals. (2.2.1)

- Use the Denton method to adjust quarterly original estimates to agree with annual benchmark estimates. (3.3.2)

- $\quad$ Replace the existing estimates of depreciation with estimates for consumption of fixed capital for all sectors other than general government. The estimates for consumption of fixed capital should be derived using the PIM methodology. (3.3.2)

- Investigate the feasibility of developing estimates for the non-observed economy using employment estimates from the Labour Force Survey (conducted by KOSTAT) and employment estimates from other data sources used to compile the national accounts. (3.3.2)

- Use a trend formula to allocate annual current price general government consumption of fixed capital to quarters rather than dividing the annual estimate by four. (3.3.2)

- $\quad$ Aim to remove the statistical discrepancy between the production and expenditure measures of GDP, on an annual basis, by compiling balanced annual SUT tables. (3.4.3)

- $\quad$ Periodically undertake an analysis of revisions to movements in quarterly GDP (and its components) in current price and volume terms between preliminary and final estimates from 1999 forward (the first year that seasonally adjusted estimates were published). (3.5.1)

- $\quad$ Encourage greater integration of the various areas in the ESD involved in compiling parts of the SNA framework by locating all of the relevant teams in one organizational unit. This unit could include the following teams: National Income Statistics Team, National Balance Sheet Team, Input Output Team, Government Sector Team, and the Statistics Development Team. 


\section{Price Statistics (Consumer Price Index)}

\section{Prerequisites of quality}

\subsection{Legal and institutional environment}

\subsubsection{The responsibility for collecting, processing, and disseminating the statistics is clearly specified}

The Statistics Act, last revised in April 2009, establishes KOSTAT as the overarching statistics-producing agency in the country, with responsibility for compiling a range of statistics, including the CPI. Article 15 describes conditions for the designation of designated statistics-collecting agencies; andArticle 18 governs conditions and dissemination of statistics. Directive 10107 designates the consumer price survey (CPS), and Directive 10106 the Household Income and Expenditure Survey (HIES), in order to enable compilation of the CPI. In accordance with the Act, the Presidential decree law provides that the "Director of Price Statistics Division is responsible for planning and conducting the Consumer Price Survey, compiling the CPI, and disseminate the CPI."

\subsubsection{Data sharing and coordination among data-producing agencies are adequate}

Under the Statistics Act, a high-level deliberative body, the National Statistics Committee, has been established under the chairmanship of the Minister of Strategy and Finance, for the development and improvement of statistical systems as well as the creation, merger, and abolition of similar and overlapping statistics.

\subsubsection{Individual reporters' data are to be kept confidential and used for statistical purposes only}

The Statistics Act, states in Article 33.1 that "matters belonging to the confidential information of individuals, corporations, organizations, etc. that have become known in the course of collecting statistics shall be protected." Article 33.2 of the Act states "data belonging to the confidential information of individuals, corporations, organizations, etc. that have been collected for the collection of statistics shall not be used for any purpose other than that of collecting statistics." Every survey questionnaire's cover sheet includes this information, and staff of KOSTAT explain the information before any person participates in a survey. Also, the public is made aware of this provision through the posting of the Statistics Act on KOSTAT's website.

All procedures, including collection, process, storage, and dissemination are computerized. Only authorized staff are able to access the system, which is password protected. Access to individual data is restricted to the staff who need the information in the performance of their statistical duties.

Article 34 of the Statistics Act states "statistics staff, persons who have been statistics staff, persons who are engaged in or have been engaged in the business of collecting statistics after being entrusted with all or any part of such business shall not use the matters that they have 
come to know in the course of performance of duty for any purpose other than that related to duty, nor shall supply them to other persons." Articles 39 to 41 of the Statistics Act specify the penalties for violating the various confidentiality requirements. Article 39 provides that "any person who falls under any of the following subparagraphs shall be punished by imprisonment for a period not exceeding three years, or by a fine of amount not exceeding ten million won."

\subsubsection{Statistical reporting is ensured through legal mandate and/or measures to encourage response}

Article 32 of the Statistics Act mandates that respondents "shall answer the matters of survey faithfully so that reliable statistics can be collected." Article 41 of the Act prescribes penalties for non-cooperation. Respondents who are reluctant to cooperate are reminded of this provision but, in order to maintain good relations with respondents, KOSTAT does not seek to enforce these provisions through legal action. Rather, KOSTAT works on maintaining excellent relations with sample respondents to keep a high voluntary response rate (nearly 100 percent for the consumer price survey, and over 80 percent for the HIES, where the respondent burden is more substantial). Excellent relations are necessary because the KOSTAT enumerators visit the stores on a regular cycle to actually observe the prices.

Article 4 of the Act states that KOSTAT should try to reduce respondent burden. Respondent burden is not a problem in collecting prices from outlets. Also, to avoid complaints, data providers are always informed how to contact the staff of the regional branches of KOSTAT. To express appreciation, the Price Statistics Division (PSD) sends data providers gift certificates to the value of 20 thousand won.

\section{$0.2 \quad$ Resources}

\subsubsection{Staff, facilities, computing resources, and financing are commensurate with statistical programs}

Article 7 of the Statistics Law provides that "the heads of statistics-collecting agencies shall strive to secure human resources and budget necessary for the collection and dissemination of statistics." In line with this law, KOSTAT has secured an appropriate number of staff and budget to conduct the CPS and produce the CPI. Staff are knowledgeable and professional. The Price Statistics Division (PSD) has a staff of 17. These staff have to take 90 hours of education each year through workshops, seminars, and classroom work in the Statistical Training Institute. They review the monthly price data collected by staff of the regional branches, and are also responsible for item specifications and conducting quality analysis when item specifications are changed. In addition, 150 staff of regional branches of KOSTAT collect price data with a personal digital assistant to conduct the CPS. They also have to take 90 hours of education through workshops, seminars, and classroom work in the Statistical Training Institute. Recruiting high-quality staff is not a problem, and staff turnover is low. Facilities, computing resources, and financing are appropriate. The annual budget is generally stable, but is increased for the years when the CPI undergoes its five-yearly revision. 


\subsubsection{Measures to ensure efficient use of resources are implemented}

KOSTAT conducts annual performance assessments of its staff. All staff have performance targets set at the beginning of the year. Where appropriate, the PSD seeks outside academic experts such as professors and researchers to launch new compilation systems and apply new statistical methodologies, for instance, hedonic techniques to the CPI. The resources used to conduct the CPS and produce the CPI are measured yearly and compared to other statistical programs.

\subsection{Relevance}

\subsubsection{The relevance and practical utility of existing statistics in meeting users' needs are monitored}

When the PSD revises the CPI, it collects information on users' needs through meetings, surveys, and official documents. Among the main data users are the Ministry of Knowledge, the Ministry of Strategy and Finance (MOSF), the Bank of Korea (BOK), the Ministry of Food, Agriculture, Forest, and Fishery, economists, academic experts, and the private sector.

PSD staff regularly participate in the statistical meetings and seminars organized by the International Labor Organization, OECD-Purchasing Power Parity (PPP) conference, and the Ottawa Group.

In addition to seeking users' views on the five-yearly revision cycle, the PSD has a number of means to seek to improve the CPI; it maintains a users' group for the Policy Customer Relationship Management, and obtains ideas from the internal innovation plaza in KOSTAT.

\subsection{Other quality management}

\subsubsection{Processes are in place to focus on quality}

KOSTAT staff are well aware of the importance of quality in terms of their product and their internal processes. The quality aspects are covered in employee training and a formal quality awareness program to review program activities, including periodic audits of the CPI. KOSTAT works with an independent Statistics Committee, composed of business, labor, academics, and consumer advocates that regularly advise it on statistical issues. A Price Subcommittee provides input to KOSTAT on aspects of the CPI, including methodology, user needs, and potential areas for data development.

\subsubsection{Processes are in place to monitor the quality of the statistical program}

Articles 9, 10 and 11 of the Statistics Act provide that "the Commissioner of the Statistics Korea shall conduct an examination of the quality of statistics." In line with the Act, the Statistics Quality Management Team of outside experts regularly evaluates the data quality of the CPI. The resulting reports are open to the public and available on KOSTAT's website. 
Although there is no official monthly report related to monitoring the quality of the statistical program, all staff check data quality at every step of processing the data.

\subsubsection{Processes are in place to deal with quality considerations in planning the statistical program}

To ensure the quality of its statistics, KOSTAT has identified six dimensions of quality: accuracy, timeliness (punctuality), relevance, coherence, accessibility, and comparability. Since KOSTAT staff are trained that data quality is the first priority, they pursue these six dimensions in all aspects of their jobs.

The Statistics Committee provides advice on new and emerging user needs for the CPI. An ad hoc user group of around 300 people also provides insights in a twice-yearly email survey on user needs, including future improvements. PSD staff at headquarters and in the field also keep track of current developments in order to better assess future needs.

\section{Assurances of integrity}

\subsection{Professionalism}

\subsubsection{Statistics are produced on an impartial basis}

The terms and conditions under which the CPI is produced are in accordance with professional independence. KOSTAT is independent of the MOSF, with the Commissioner being appointed directly by the President. This independence derives from the Statistics Law and is recognized by the government and most users. The Statistics Commissioner is very strongly supportive of the independence of KOSTAT. KOSTAT produces its own press releases with no interference from the MOSF, which does not have prior access to the data.

KOSTAT uses its Statistical Training Institute to promote the professionalism of staff. Courses are not only for the staff of KOSTAT, but also for staff from other statistical agencies. Every year, all staff of the PSD have to participate in two courses provided by the Statistical Training Institute. In addition, the PSD runs a CPI study group to encourage its staff to be professional, where all present their research topics on CPI-related issues. The PSD sometimes also invites outside experts to give lectures.

Staff in the regional branches also take seminars and workshops on CPI issues every year.

\subsubsection{Choices of sources and statistical techniques, as well as decisions about dissemination, are informed solely by statistical considerations}

PSD staff select data sources and the statistical techniques to be used. They are conscious of respondent burden, make efforts to keep reporting requirements to a minimum, and continuously keep up to date on the latest methodologies. PSD staff also make the decisions on the dissemination of the CPI. 


\subsubsection{The appropriate statistical entity is entitled to comment on erroneous interpretation and misuse of statistics}

The PSD monitors news media for stories about the CPI, and has the authority to comment on erroneous interpretations or misuse of statistics in the news media.

\subsection{Transparency}

\subsubsection{The terms and conditions under which statistics are collected, processed, and disseminated are available to the public}

Details of all aspects of the CPI are posted on KOSTAT's website, as well as in news releases and in monthly and annual reports. The public therefore has free access to this information. An advance release calendar is posted one year in advance. The weights and surveyed items of the CPI are revised every five years. The public is informed in bulletins, briefings, news releases, and on the website when major changes are introduced in methodology, statistical techniques, and sources, including weights and surveyed items.

\subsubsection{Internal governmental access to statistics prior to their release is publicly identified}

There is no internal government access to statistics prior to their release.

\subsubsection{Products of statistical agencies/units are clearly identified as such}

KOSTAT's press releases clearly indicate that the CPI is compiled by KOSTAT. Similarly, KOSTAT's website identifies KOSTAT as the source for the CPI data. News releases and publications carry KOSTAT's logo, as well as the name of the division and person responsible and their telephone number.

\subsubsection{Advance notice is given of major changes in methodology, source data, and statistical techniques}

The weights and surveyed items of the CPI are revised every five years. The PSD informs the public through articles in bulletins, briefings, and news releases on the KOSTAT website when major changes are introduced in methodology, statistical techniques, or sources including weights and surveyed items.

\subsection{Ethical standards}

\subsubsection{Guidelines for staff behavior are in place and are well known to the staff}

Before they begin their jobs, all staff receive a special program of training on ethics. This training is repeated twice a year. All staff have to follow KOSTAT's Code of Ethics, which covers issues such as misrepresentation, misuse of data, and political interference, and which is distributed to staff and posted on the premises. 


\section{Methodological soundness}

\subsection{Concepts and definitions}

\subsubsection{The overall structure in terms of concepts and definitions follows internationally} accepted standards, guidelines, or good practices

The concepts and definitions for the CPI follow internationally accepted standards such as the 2003 SNA and the ILO International Consumer Price Index Manual, 2004 (CPIM 2004). The level of detail for goods and services is sufficient to support detailed analyses of price movements as indices are compiled for the 3-digit groups of the Classification of Individual Consumption by Purpose (COICOP).

\subsection{Scope}

2.2.1 The scope is broadly consistent with internationally accepted standards, guidelines, or good practices

The CPI weights are derived from the HIES, which covers households regardless of the number of persons. However, it excludes households whose primary activity is farming or fishing; such households are covered by separate Household Economic Surveys. Consideration is being given to including such households in the CPI weights.

The HIES records the purchases of market goods and services for consumption in residential households. It does not include goods and services produced by the household for own consumption and sales of illegal market goods and services, but these are not large in Korea.

The "All items," or headline, CPI does not include owner-occupied dwellings. However, a supplementary index is published which includes imputed rentals of owner-occupied dwellings, along with a measure of core inflation (All items excluding agriculture products and oils).

\subsection{Classification/sectorization}

2.3.1 Classification/sectorization systems used are broadly consistent with internationally accepted standards, guidelines, or good practices

The classification and sectorization used in the compilation of the CPI are in broad conformity with the 1993 SNA, COICOP, and the ILO's CPIM 2004 guidelines.

\subsection{Basis for recording}

\subsubsection{Market prices are used to value flows and stocks}

For the CPI weights, consumption expenditure is valued at purchasers' prices which include trade and transport margins and any taxes less subsidies on products. 
The prices collected are the purchasers' prices of marketed goods and services prevailing at the time of field collection. Product specifications are provided at a detailed level covering all price determining characteristics (including the terms of the transaction) so that specific transaction prices are collected.

\subsubsection{Recording is done on an accrual basis}

Prices of goods and services are recorded in the period in which they are purchased. The price collection period depends on the nature of the goods and services. Prices of products with volatile prices such as fresh fruit and vegetables and fish are collected three times a month, while the prices of other products are collected once a month.

\subsubsection{Grossing/netting procedures are broadly consistent with internationally accepted standards, guidelines, or good practices}

Net expenditure on used goods is not obtained from the HIES and they are therefore not included in the CPI.

\section{Accuracy and reliability}

\subsection{Source data}

\subsubsection{Source data are obtained from comprehensive data collection programs that take into account country-specific conditions}

To analyze population distribution, data are obtained from the Population and Housing Census conducted by KOSTAT and Population Registers maintained and updated continuously by the municipalities. Since the Population Census has been conducted every five years, the areas and cities for price collection are revised following each Census. From 2005 data, 150 representative areas in 38 cities were selected to reflect the current population distribution.

The outlet samples for the price collection come from the Census of Wholesale and Retail Trade and the Annual Survey of Wholesale and Retail Trade. When outlets need changing, staff in regional branches replace them with new outlets following head office guidelines. The outlets include department stores, supermarkets, discount stores, specialized stores, and service establishments.

Rental values are collected from the House Rents Survey which is based on the same sample of households in the Labor Force Survey. This survey collects rents from approximately 9,000 households each month. The sample frame comes from the Housing Census and sample households are selected by multistage sample design.

The primary source for CPI item weights is the HIES. The sample of the HIES is about 9,000 households excluding farm and fishery households from all over the country (urban and rural). The HIES also excludes institutional households such as dormitory, nursing home, and 
orphan asylums. The HIES is conducted monthly and requires households to maintain a diary of daily expenditure. It has a multistage sample design using Probability Proportionate to Size based on population census data at each stage. To calculate the CPI weights, annual average expenditure is used in order to take account of seasonal variations in household expenditure patterns.

The response rate of the HIES is about 82 percent of the original sample.

The CPS is the source of monthly prices for index compilation. The items for pricing are selected according to their relative importance in the share of average expenditures of the HIES. The selection criterion is that an item needs to account for more than $1 / 10,000$ of the average expenditures of the HIES and be considered representative of other similar items.

Occasionally, two or more specifications for an item are included when one specification is insufficient to represent the price movement of the item. The most popular products in terms of sales value are selected for the price collection. Regional staff collect prices by personal visit, telephone, and via the internet for the 489 items (represented by about 880 product specifications) contained in the consumer basket. Prices are collected from about 22,000 outlets and service establishments in 38 cities. Prices for livestock products and agricultural and fisheries products are collected three times a month because of their volatility while prices of other commodities and services are collected once a month.

The prices collected are normal prices (actual transaction prices) excluding abnormal prices such as (i) temporary irregular prices caused by disaster or similar conditions, (ii) prices of goods that are sold on a credit and installment basis, (iii) discounted prices due to volume purchases, and (iv) prices of smuggled goods.

When a product's prices do not vary between regions, they are collected centrally, e.g., tobacco, magazines, electricity charges, postage and administration service charges.

Periodically, the PSD conducts ad hoc surveys to obtain detailed weights for the rebase and introduce new item specifications. For the 2005 rebase, an ad hoc survey of restaurants was undertaken to select a sample of meals for pricing and to derive weights for each meal. When new products are introduced, ad hoc surveys are conducted to determine products for pricing and derive the market structure.

As part of the five-yearly index rebase process, consultations with users are undertaken. Also, the results of a user satisfaction survey, conducted semiannually for the Policy Customer Relationship Management, are used to keep abreast of new developments and improve the CPI.

Through participating in international conferences, the PSD monitors international standards in order to maintain the relevance of the CPI compilation system.

The PSD also cooperates with the Statistics Research Institute of KOSTAT to investigate new developments for the CPI. 
3.1.2 Source data reasonably approximate the definitions, scope, classifications, valuation, and time of recording required

The HIES and the CPI use the same definitions, scope, and classifications. Therefore, the two datasets are consistent.

\subsubsection{Source data are timely}

Since the CPS and the House Rents Survey are conducted monthly, they support the monthly publication of the CPI.

The HIES is conducted monthly, so information about items and weights is available on a timely basis.

\subsection{Assessment of source data}

3.2.1 Source data-including censuses, sample surveys, and administrative records—are routinely assessed, e.g., for coverage, sample error, response error, and nonsampling error; the results of the assessments are monitored and made available to guide statistical processes

According to Articles 9, 10, and 11 of the Statistics Act, KOSTAT is required to evaluate all its surveys. The Statistics Quality Management Team is responsible for this evaluation and uses a quality evaluation system to routinely assess the Population Census, the HIES, and House Rent Survey.

When staff in regional branches conduct the CPS and send the data to head office, PSD staff check the accuracy of price changes for every item.

No administrative data or other secondary sources are used in the compilation of the CPI.

\subsection{Statistical techniques}

\subsubsection{Data compilation employs sound statistical techniques to deal with data sources}

Prices are collected in 150 areas of 38 cities. The areas in each city are selected in proportion to the expenditures of the city's population. For example, since Seoul has the highest expenditures of any city in Korea, 11 of the 150 areas are selected from Seoul.

For the first level of aggregation, the price relative for an item in a city is derived as its average (arithmetic mean) price in the current month divided by its average price (arithmetic mean) in the base year 2005. This index based on the ratio of average prices is a Dutot index. Products within an elementary aggregate are very homogenous because, in general, for an item, the same product specifications are priced from each selected outlet. Staff in regional branches only collect prices for the products nominated by the PSD. 
The Laspeyres formula is used for higher levels of aggregation, with the weights updated every five years. The Korean CPI is a pure Laspeyres index because the weight period and the price reference period are the same.

When a price observation is temporarily unavailable in a given month, its price is imputed by the price movements of similar products for the same item in the same geographic area. Depending upon the circumstances, the carry-forward method is sometimes applied.

For seasonal items such as fresh fish, fruit, and vegetables that are not available on the market during the off-season, the last available prices are used to calculate the index until new prices are available.

When a specific variety is permanently unavailable from an outlet, another product from the same outlet that most closely meets the specifications of the previous variety, and has gained market share, is selected as a replacement.

To adjust for quality differences, an appropriate method from a variety of quality adjustment techniques is used depending on the circumstances. The alternative methods include:

- $\quad$ The direct comparison method. This approach is applied when the quality of an old item and a new item is the same. The index is constructed by direct comparison of the prices of two items. A replacement item often has modified names and functions. However, if it is deduced that there is no actual quality difference, any price change is considered to be a pure price change and shown in the index.

- $\quad$ Expert judgment. This method involves the calculation of the pure price element of the nominal price change. An expert group of staff in the PSD assesses highly complex items such as household appliances whose characteristics and functions are frequently modified to reflect improvements and the adoption of new technology.

- Quantity adjustment. This method involves scaling the price of the old item, or the new item, by the ratio of the respective quantities. The index is calculated as a price per unit of size, number or weight, etc.

- Production cost/option cost. If feasible, staff adjust the price of an old item by the marginal resource cost of providing the additional features. However, it is often difficult to obtain data on manufacturers' production costs as the information is confidential.

- $\quad$ Linking or splicing to show no price change. The price difference is assumed to be fully attributable to a change in quality. When an old item and a new item are totally different, it is not easy to separate out how much of these differences are attributable to pure price change and to quality change.

- Hedonic regression techniques. These methods are used when the all the major characteristics of the item that influence its price change can be obtained. The PSD 
has applied the hedonic approach to desk computers and notebook computers since 2005.

\subsubsection{Other statistical procedures (e.g., data adjustments and transformations, and statistical analysis) employ sound statistical techniques}

The weights of the CPI are derived from the HIES, which conforms to the 1993 SNA. New items are introduced at the time weights are updated each five years.

Owner-occupied housing is not included in the CPI headline index, but it is included in a supplementary index.

The PSD uses the current weight reference period which is the same price reference period.

The weight reference period has been updated every five years; it is currently 2005 .

\subsection{Assessment and validation of intermediate data and statistical outputs}

\subsubsection{Intermediate results are validated against other information where applicable}

The CPI is compared with relatable estimates from other major price indices such as the PPI, export price index, and import price index which are produced by the BOK.

\subsubsection{Statistical discrepancies in intermediate data are assessed and investigated}

From price collection to data processing, staff check and query data at a detailed level. Staff in the PSD are commodity specialists focusing on particular products through monitoring developments published in magazines and websites and through regular communication with contacts in manufacturing enterprises. Therefore, unusual movements in the index arising from large changes in particular sectors may be anticipated and investigated as necessary.

\subsubsection{Statistical discrepancies and other potential indicators of problems in statistical outputs are investigated}

Any discrepancies resulting from the use of inconsistent imputation techniques for missing data, or aggregation inconsistencies, are investigated and rectified.

\subsection{Revision studies}

\subsubsection{Studies and analyses of revisions are carried out routinely and used internally to inform statistical processes (see also 4.3.3)}

Following each five-yearly update of weights and items, the effects of substitution bias on the CPI are studied. For the period that the CPI is recompiled from the base year through to the current period (about two years), a revision study is undertaken to analyze the weight shifts, new items included in the index, old items removed from the index, and changes in coverage and methodology. 
The revised CPI index is systematically lower than the original index after the weight revision because of the use of the Laspeyres formula. During the study, a chain Laspeyres index, a Paasche index and a Fisher index are compiled and reviewed to assist in the evaluation of the revision effects. A chain Laspeyres index is published yearly as a supplementary measure.

\section{Serviceability}

\subsection{Periodicity and timeliness}

\subsubsection{Periodicity follows dissemination standards}

The CPI is published monthly, which meets the requirements of the SDDS.

\subsubsection{Timeliness follows dissemination standards}

Usually the CPI is released on the first business day of the month after the reference month, which meets the requirements of the SDDS.

\subsection{Consistency}

\subsubsection{Statistics are consistent within the dataset}

The upper-level indices are calculated by aggregating the lower level indices; the indices are therefore consistent in aggregation.

\subsubsection{Statistics are consistent or reconcilable over a reasonable period of time}

Annual indices with the price reference period of $2005=100$ are published for the overall CPI from 1965. Thus, consistent time series data are available for about a 40 -year period. When revised series are introduced, every five years, the CPI is recalculated on the basis of new price reference period.

When unusual changes in economic trends occur, an explanation is provided in the monthly press release. Users have access to the press releases in hard copy or on the KOSTAT website.

\subsubsection{Statistics are consistent or reconcilable with those obtained through other data sources and/or statistical frameworks}

For relatable products, PPI and CPI price trends are compared. 


\subsection{Revision policy and practice}

\subsubsection{Revisions follow a regular and transparent schedule}

Since 1965, the CPI rebase has been conducted every five years with for years ending 0 or 5 . This is well known to the public. The rebase schedule is posted on the KOSTAT website. The PSD is preparing for the revision based on $2010=100$.

\subsubsection{Preliminary and/or revised data are clearly identified}

The monthly released CPI is final, not preliminary.

The CPI is revised when the base-year is changed. At the time of the new CPI time series, the new release includes revision information.

\subsubsection{Studies and analyses of revisions are made public (see also 3.5.1)}

The CPI revisions are measured and assessed. The results are explained in the news release, the annual and monthly report on the CPI and the KOSTAT website.

\section{Accessibility}

\subsection{Data accessibility}

\subsubsection{Statistics are presented in a way that facilitates proper interpretation and meaningful comparisons (layout and clarity of text, tables, and charts)}

The CPI is publicly released in various formats and media, including very detailed data, to ensure users' needs are met.

The monthly news release includes a short analysis of data for the nation and 16 separate areas. The main features of the index are clearly summarized through time-series tables, commentary, and charts. The news release is also posted on the KOSTAT website. Monthly and annual CPI reports containing more tables than the news release are also published.

\subsubsection{Dissemination media and format are adequate}

To provide more detailed information of the CPI, the Korean Statistical Information System (KOSIS) database, which includes detailed breakdowns and long time-series is also provided: http://www.kosis.kr/eng/e_stat_OLAP.jsp?tbl_id=DT_1J07001\&org_id=101\&vwcd=MT_E TITLE\&path=\&oper $\_\mathrm{YN}=\mathrm{Y} \&$ lang_mode $=$ eng

From the database, users can access all kinds of tables free of charge.

However, there are significant problems of accessibility to KOSIS on which the relevant data and metadata are presented. Upon seeking to access KOSIS, users are asked to download locally produced software; however, this software is not recognized by users, particular 
non-Korean users, and institutional firewalls prevent the required downloading or, at a minimum accompany it with strong computer security warnings. In practical terms therefore users cannot access these data or their accompanying metadata electronically. (They are still accessible through print publications or commercial vendors.) KOSTAT is aware of this problem, and has indicated that it expects financing to be available by the end of 2010, but it will take until 2013 to resolve the problem.

\subsubsection{Statistics are released on a preannounced schedule}

The CPI is released at 1:30 p.m. on the first business day each month. The dates when the CPI is to be released are announced in advance in the January news release and the KOSTAT website. The CPI is released punctually according to the preannounced schedule.

\subsubsection{Statistics are made available to all users at the same time}

The public is informed of the forthcoming CPI release and how to access the data via the internet and news media.

The CPI is made available to all interested users simultaneously.

\subsubsection{Statistics not routinely disseminated are made available upon request}

A range of publications and databases satisfy users' needs through providing both summary and very detailed tables. No requests for the provision of further breakdowns have been received.

\subsection{Metadata accessibility}

5.2.1 Documentation on concepts, scope, classifications, basis of recording, data sources, and statistical techniques is available, and differences from internationally accepted standards, guidelines, or good practices are annotated

Users can easily access CPI metadata information because it is presented in publications and news releases. It is also presented on the KOSTAT website. Information such as the purpose of the index, concepts, reference periods, classifications, compilation methods, etc. is included.

As noted above, however, there is a significant problem with access to the metadata through KOSIS, because of the use of software that is not internationally recognized.

The SDDS/GDDS metadata and SDDS summary methodologies are regularly reviewed and updated.

\subsubsection{Levels of detail are adapted to the needs of the intended audience}

While the CPI information in the news release is designed for ordinary users, the information in the annual report and metadata is intended for experts. 


\subsection{Assistance to users}

\subsubsection{Contact points for each subject field are publicized}

The news release and publication contain staff contact names and their telephone and fax numbers. In addition, users can find this information on the KOSTAT website. The website has a "Frequently Asked Questions (FAQs)" segment for common inquiries. KOSTAT has rules regarding the promptness of response to enquiries.

5.3.2 Catalogs of publications, documents, and other services, including information on any charges, are widely available

All KOSTAT publications contain information on all of the surveys conducted by KOSTAT, each publication's name, release date, purpose, contents and price. The KOSTAT website also has a Statistical Shopping Mall for publications. Through this site, users have access to much more information and can purchase the publications. 
Table 2. Data Quality Assessment Framework (July 2003): Summary of Results for Price Statistics (Consumer Price Index)

(Compiling Agency: KOSTAT)

Key to symbols: NA $=$ Not Applicable; $O=$ Practice Observed; LO $=$ Practice Largely Observed; LNO $=$ Practice Largely Not Observed; NO $=$ Practice Not Observed; SDDS $=$ Complies with SDDS Criteri

\begin{tabular}{|c|c|c|c|c|c|c|}
\hline \multirow{2}{*}{ Element } & \multirow{2}{*}{ NA } & \multicolumn{4}{|c|}{ Assessment } & \multirow{2}{*}{ Comments } \\
\hline & & $\mathbf{O}$ & LO & LNO & NO & \\
\hline \multicolumn{7}{|l|}{ 0. Prerequisites of quality } \\
\hline 0.1 Legal and institutional environment & & $\mathrm{X}$ & & & & \\
\hline 0.2 Resources & & $\mathrm{X}$ & & & & \\
\hline 0.3 Relevance & & $\mathrm{X}$ & & & & \\
\hline 0.4 Other quality management & & $\mathrm{X}$ & & & & \\
\hline \multicolumn{7}{|l|}{ 1. Assurances of integrity } \\
\hline 1.1 Professionalism & & $\mathrm{X}$ & & & & \\
\hline 1.2 Transparency & & $\mathrm{X}$ & & & & \\
\hline 1.3 Ethical standards & & $\mathrm{X}$ & & & & \\
\hline \multicolumn{7}{|l|}{ 2. $\quad$ Methodological soundness } \\
\hline 2.1 Concepts and definitions & & $\mathrm{X}$ & & & & \\
\hline 2.2 Scope & & $\mathrm{X}$ & & & & \\
\hline 2.3 Classification/sectorization & & $\mathrm{X}$ & & & & \\
\hline 2.4 Basis for recording & & $\mathrm{X}$ & & & & \\
\hline \multicolumn{7}{|l|}{ 3. Accuracy and reliability } \\
\hline 3.1 Source data & & $\mathrm{X}$ & & & & \\
\hline 3.2 Assessment of source data & & $\mathrm{X}$ & & & & \\
\hline 3.3 Statistical techniques & & & $\mathrm{X}$ & & & $\begin{array}{l}\text { Out of season prices should be imputed using an unbiased } \\
\text { methodology rather than simply carrying forward the last } \\
\text { observation. }\end{array}$ \\
\hline $\begin{array}{l}\text { 3.4 Assessment and validation of intermediate data and } \\
\text { statistical outputs }\end{array}$ & & $X$ & & & & \\
\hline 3.5 Revision studies & & $\mathrm{X}$ & & & & \\
\hline \multicolumn{7}{|l|}{ 4. Serviceability } \\
\hline 4.1 Periodicity and timeliness & & $\mathrm{X}$ & & & & \\
\hline 4.2 Consistency & & $\mathrm{X}$ & & & & \\
\hline 4.3 Revision policy and practice & & $\mathrm{X}$ & & & & \\
\hline \multicolumn{7}{|l|}{ 5. Accessibility } \\
\hline 5.1 Data accessibility & & & $\mathrm{X}$ & & & $\begin{array}{l}\text { There is a significant problem with access to the data through } \\
\text { the KOSIS, because of the use of software that is not } \\
\text { internationally recognized. }\end{array}$ \\
\hline 5.2 Metadata accessibility & & $\mathrm{X}$ & & & & \\
\hline 5.3 Assistance to users & & $\mathrm{X}$ & & & & \\
\hline
\end{tabular}




\section{Recommendations}

- $\quad$ In the context of the 2010 CPI rebase, consult widely with users (especially the BOK) to determine the current principal use of the CPI (e.g., whether it is the measurement of consumption or inflation), define the most appropriate headline measure (e.g., including or excluding owner-occupied dwellings), decide on the preferred treatment of owner-occupied dwellings (imputed rentals or net acquisitions) and define core or underlying inflation. Change the presentation of CPI statistics as appropriate. Consider whether to give greater prominence to a broader measure of price change than the present "all items" index that excludes owner-occupied dwellings.(2.2.1)

- $\quad$ Assess the feasibility of including farming and fishing households within the scope of the CPI either by extending the scope of the HIES, or incorporating data on expenditure patterns from the Farming and Fishing Household Economic Surveys during the weight calculation exercise. (2.2.1)

- $\quad$ Review the methodology used for imputing missing seasonal product prices with the aim of removing the bias associated with using the simple carry-forward method, which should only be used in particular circumstances and with caution. (3.3.1)

- As part of the consultations planned for the forthcoming rebasing program, consult on the proposal to change from a five-yearly to a three-yearly rebase cycle by reference to a detailed analysis of the extent of substitution bias associated with the use of the Laspeyres formula. Assess the relative improvement obtained by adopting a three-year cycle compared with adopting an annual cycle. (3.3.1). 


\section{Price Statistics (Producer Price Index)}

\section{Prerequisites of quality}

\section{$0.1 \quad$ Legal and institutional environment}

\subsubsection{The responsibility for collecting, processing, and disseminating the statistics is clearly specified}

The Producer Price Index (PPI) is compiled in accordance with Article 86 of the Bank of Korea Act (2004-2008) which states that "The Bank of Korea may, when necessary for the formulation of its monetary and credit policies, collect and compile statistics on money and banking, public finances, prices, wages, production, the balance of payments and other basic economic statistical series and conduct economic research and for such purposes request any materials or information from government organizations and any juristic or individual person." In addition, the Statistics Act (2007-2009) specifies all aspects of the production of statistics in Korea. Article 15 describes conditions for the designation of designated statistics collecting agencies; and Article 18 governs conditions for the collection and dissemination of statistics. As a designated agency, the Bank of Korea (BOK) is also governed in its statistical work by the remaining provisions of the Statistics Act.

\subsubsection{Data sharing and coordination among data-producing agencies are adequate}

Under the Statistics Act, a high-level deliberative body, the National Statistics Committee, has been established, under the chairmanship of the Minister of Strategy and Finance, for the development and improvement of statistical systems as well as the creation, merger, and abolition of similar and overlapping statistics.

The BOK and KOSTAT cooperate well in the exchange of information required for compiling the PPI. Detailed data from the mining and manufacturing census and the agriculture census are provided to the BOK under a formal arrangement with KOSTAT. Data on shipments obtained from KOSTAT are used to derive the weights.

\subsubsection{Individual reporters' data are to be kept confidential and used for statistical purposes only}

The confidentiality of individual respondents' data collected by the BOK is guaranteed by the Statistics Act (Articles 33 and 34), which requires that material of a confidential nature belonging to individuals, juristic persons, or organizations collected for statistical compilation shall be protected from disclosure and used only for statistical compilation.

All BOK staff are bound by the Bank of Korea Act, section 42, which specifies that they should not divulge confidential matters to outsiders. Similar provisions are contained in Article 20 of the Articles of Incorporation of the BOK, as well as in the code of conduct of the staff. All staff must take a written oath to commit to follow the code of conduct. 
The Guidelines on Compilation and Dissemination of Statistics (September 1999), prepared by the management of the BOK's Economic Statistics Department (ESD), provide specific guidelines for the compilation and dissemination of statistics. In particular, access to confidential data is restricted to staff directly involved through restricting access to offices and ensuring computer security. New staff, including temporary staff, are informed of the guidelines.

The integrity of the staff is held to be of critical importance at the highest levels of the BOK. Any breach of confidentiality would likely be reported in detail in the press; to date, there have been no such breaches. Under the Statistics Act, Article 39, breaches of confidentiality may result in imprisonment.

\subsubsection{Statistical reporting is ensured through legal mandate and/or measures to encourage response}

The Bank of Korea Act, Article 87, and the Statistics Act together provide the legal basis for the collection of statistical information for compiling statistics. In the conduct of statistical collections, the BOK explains to survey respondents the importance of the data being sought for policy formulation in order to encourage response, and has found the approach mostly successful. However, the BOK has no legal power itself to impose penalties for non-compliance with statistical reporting requirements. Under the Statistics Act, Article 41, KOSTAT can impose fines for non-response to reasonable requests. The BOK can ask KOSTAT to levy such penalties on its behalf, but so far has never needed to do so.

\section{$0.2 \quad$ Resources}

\subsubsection{Staff, facilities, computing resources, and financing are commensurate with statistical programs}

The BOK has 21 staff (11 professional and 10 contractual) assigned to the PPI. The staff are knowledgeable about PPI concepts, methods, and practices. All staff undertake internal training in prices concepts, methods and practices, and more senior staff receive external training.

The staff and resources allocated are sufficient to maintain the PPI program; however, additional staff resources may be required for the implementation of annual chaining of the index.

\subsubsection{Measures to ensure efficient use of resources are implemented}

In the middle of July of each year, the PPI team in the ESD prepares its budget for the following year, which the BOK's Planning Department evaluates. During the year, the program and use of resources are monitored on a quarterly basis. The program is reviewed annually. Staff performance is assessed regularly. On occasion, outside consultants are used, for instance to develop statistical compilation systems. 


\subsection{Relevance}

\subsubsection{The relevance and practical utility of existing statistics in meeting users' needs are monitored}

The BOK does not maintain any external formal users' advisory committee on the PPI as such, but maintains an internal committee, the Quality Evaluation Advice Committee. Professional staff receive feedback on users' needs by email, phone, and fax. The BOK uses its Economic Statistics System (ECOS: http://ecos.bok.or.kr) website to communicate with users. Users can submit questions and comments about economic statistics at this website. In addition, surveys about users' needs are conducted regularly through this site. Academics have ongoing contact with the BOK, and staff periodically undertake Google searches to obtain feedback. Also, the BOK may receive feedback from the regular program of contacts that KOSTAT maintains with users.

\section{$0.4 \quad$ Other quality management}

\subsubsection{Processes are in place to focus on quality}

In order to improve the quality of statistics, the Statistics Act, Articles 9 and 10, mandate regular and one-off evaluations. The BOK conducts an Independent Quality Evaluation every five years, and a Quality Self-Evaluation every year. It also periodically participates in international evaluations, such as the IMF's Data ROSC program. The BOK has established three internal committees to assist in research and to promote quality: the Quality Evaluation Advice Committee, the Source Data Improvement Committee, and the Seasonal Adjustment Committee.

\subsubsection{Processes are in place to monitor the quality of the statistical program}

The Audit Department of the BOK regularly reviews the consistency and accuracy of the published statistics, together with the level of budget and expenses. The ESD prepares the annual and long-term plans for the statistical program, and the Budget and Management Department checks the conduct of these plans quarterly.

\subsubsection{Processes are in place to deal with quality considerations in planning the statistical program}

When the BOK plans its statistical programs, quality issues are addressed explicitly and given priority consideration. Tradeoffs among the dimensions of quality (e.g., resource availability, timeliness, and accuracy/reliability) are recognized. 


\section{Assurances of integrity}

\subsection{Professionalism}

\subsubsection{Statistics are produced on an impartial basis}

The PPI is compiled on an impartial basis. Under the Bank of Korea Act, Article 3, the BOK is independent from the government in its operations, and this independence is personally stressed by the highest levels of the BOK. There is no external pressure on the BOK with respect to the content or release of the statistics. Staff are encouraged to prepare research papers on statistical issues that are published under their names; seminars and conferences are arranged at which staff and outside experts participate.

\subsubsection{Choices of sources and statistical techniques, as well as decisions about dissemination, are informed solely by statistical considerations}

The choices of sources, statistical techniques, and dissemination of the PPI are made freely by the BOK, and informed solely by statistical considerations. BOK staff are highly professional and make independent decisions on statistical matters. PPI staff select data sources and the statistical methods to be used. Because of the voluntary nature of reporting by establishments, staff are conscious of reporting burden. They continually keep up with methodological developments and have the Producer Price Index Manual, 2004 (PPIM 2004) on their website, translated into Korean.

\subsubsection{The appropriate statistical entity is entitled to comment on erroneous interpretation and misuse of statistics}

The BOK monitors media coverage of its statistical products daily. Where there is an erroneous interpretation of statistics, it seeks correction from the media. It also issues its own press releases to correct misinterpretation or misuse of statistics.

\subsection{Transparency}

\subsubsection{The terms and conditions under which statistics are collected, processed, and disseminated are available to the public}

The Bank of Korea Act and the Statistics Act are available on the websites of the BOK (http://www.bok.or.kr) and KOSTAT (http://www.kostat.go.kr). Detailed descriptions of the methodologies and techniques used are presented on these websites and in various publications covering the datasets. The Economic Statistics Department (ESD) also maintains an Information Center where users can obtain additional information on the statistics. 


\subsubsection{Internal governmental access to statistics prior to their release is publicly identified}

There is no pre-release of statistics to government ministries.

\subsubsection{Products of statistical agencies/units are clearly identified as such}

The BOK's publications and press releases clearly identify the BOK as the publisher by name, logo, and insignia.

\subsubsection{Advance notice is given of major changes in methodology, source data, and statistical techniques}

Advance notice is provided to the press, or through the BOK's website, when the BOK is preparing a major change in methodology, source data or statistical technique, for instance when planning to introduce advance release calendars for its statistical products.

There have been no changes in methodology for the PPI since the last rebase (to 2005) in 2008. For the next rebase (to 2010) in 2013, changes in methodology and data sources will be announced.

\subsection{Ethical standards}

\subsubsection{Guidelines for staff behavior are in place and are well known to the staff}

There are clear ethical guidelines for official statistics in the Guidelines on Compilation and Dissemination of Statistics issued to all staff in September 1999. This document is given to all new staff including contract workers and displayed in work areas. Periodically, the Personnel Department will remind staff of aspects of professional behavior. High ethical standards are expected of, and observed by, BOK staff.

\section{Methodological soundness}

\subsection{Concepts and definitions}

\subsubsection{The overall structure in terms of concepts and definitions follows internationally accepted standards, guidelines, or good practices}

The 2005 based PPI uses 1993 SNA concepts and definitions for the recording and valuation of product prices and weights. Since the previous Data ROSC for Korea, the PPI has been rebased from year 2000 to year 2005, in order to reflect changes in the economic structure during the previous five years and be compatible with other economic indicators such as the IPI and the CPI. 
The PPI refers to output prices, and the weighting concept is based on market output of finished goods and services, with indices published for detailed industry groups and commodities and by stage of processing.

The principles for the selection and specification of goods and services for repeat pricing follow the recommendations of the international PPIM 2004. The product specifications include all price determining characteristics including both product and transaction characteristics.

\subsection{Scope}

\subsubsection{The scope is broadly consistent with internationally accepted standards, guidelines,} or good practices

The index covers all goods and services produced by domestic enterprises in the selected sectors which were sold to domestic markets in 2005. It excludes exports and imports which are covered by the Export Price Index and Import Price Index. The goods industries covered are agriculture, forestry and marine, mining, manufacturing and electricity, gas and water; and the following service industries are covered: transportation, telecommunications, financial services, real estate, leasing and renting, advertising and professional, scientific and technical services.

Works of art, ships, aircraft, weapons, and jewelry are excluded because of difficulties in obtaining comparable prices over time. Also excluded are services such as defense, education, and social security because of difficulties in conceptually defining their prices.

Transactions in free trade zones and bonded warehouses are excluded, although this does not affect the PPI because its scope excludes imports and exports. These exclusions do, however, impact on the import and export price indices.

\subsection{Classification/sectorization}

\subsubsection{Classification/sectorization systems used are broadly consistent with internationally accepted standards, guidelines, or good practices}

The PPI uses the 1993 SNA concepts of institutional units and transactions.

The KSIC, revised in December 2007, is used for the classification of industries and commodity groups within industries. The KSIC has five-digit industry codes, appended with three-digit commodity codes. This commodity classification does not conform to any international standard. A Korean Central Product Classification (KCPC), derived from the Central Product Classification (CPC), is currently under development at KOSTAT and will be used by the BOK for the next PPI rebase. 
Goods are classified into four major industrial groupings, and services into eight groupings. These are further divided into 47 groups and 107 subgroups.

There is also a supplementary specialized classification by generic commodity groupings, namely: foods and non-foods, fresh foods and other items, energy and other items, information technology and other items, and the PPI excluding fresh foods and energy.

\section{$2.4 \quad$ Basis for recording}

\subsubsection{Market prices are used to value flows and stocks}

The PPI weights and prices conform to 1993 SNA valuation rules.

The weights are derived from market output valued at basic prices, excluding trade and transport margins and product taxes.

The specifications of the products for pricing are designed to measure "pure price change" and include all price determining characteristics including details on the terms of the transaction such as timing of payment, packaging/containers, and delivery arrangements.

\subsubsection{Recording is done on an accrual basis}

The PPI follows the 1993 SNA timing rules for recording flows and stocks. The product output data used to derive the weights are recorded in the period in which they are produced. Similarly, producer prices are recorded at the time they are produced.

\subsubsection{Grossing/netting procedures are broadly consistent with internationally accepted standards, guidelines, or good practices}

Stage of processing indices are calculated by splitting the commodity weights in proportion to their end use (final demand, intermediate consumption, and raw materials) and then aggregating the commodity indices according to each stage, consistent with 1993 SNA concepts.

\section{Accuracy and reliability}

\subsection{Source data}

3.1.1 Source data are obtained from comprehensive data collection programs that take into account country-specific conditions

The major sources for PPI weights are the two well-established annual industry censuses: mining/manufacturing and agriculture. For services, weights are estimated on the basis of input-output data. 
The censuses are based on a centralized business register that is maintained through the conduct of an annual units survey. Rigorous testing of the collection form is undertaken, especially when new questions are added.

Enumerators visit all the establishments and obtain a very good level of cooperation. Response rates are around 99 percent.

The major data source for prices is a monthly survey of prices of selected representative product specifications from a sample of establishments.

For mining and manufacturing, the 2005 industry census was used as the sampling frame for selecting commodities and establishments, while for agriculture the 2005 agricultural census was used. In the case of services, 22 industries for which pricing were assessed as being feasible were selected for incorporation in the index.

Data for mining, manufacturing, and agriculture are available at the five-digit industry level and the eight-digit commodity level. The censuses include unincorporated enterprises so that their shipment and sales information are covered. The data generally only measure market output and therefore do not include estimates of production for own use.

The establishments selected for the price survey represent 88 percent of the PPI universe. The weight of the selected sample of mining, manufacturing, and agriculture establishments covers over 90 percent of output in most major groups, and 70 percent to 80 percent for the selected service industries.

Commodities are selected for the index regimen using cutoff sampling based on the relative importance of the commodities. For mining, manufacturing and agriculture, all commodities with a relative importance of .0001 are selected. For services, a cutoff of .0005 is used for the selected industries.

Establishments are also selected using cutoff sampling, generally with the three or four largest establishments selected in each industry. For service industries, the three or four largest establishments in each region are selected.

Data are collected for 801 goods and 83 services from 6,100 establishments. Each month, 4,100 prices for goods are collected and 2,000 prices for services. Transaction specifications are selected at the establishment level for typical transactions using the following criteria to ensure that continuous price series can be obtained:

- $\quad$ The transaction amount.

- The representativeness of price changes over time.

- The possibility of price series continuity. 
Prices are collected once per month for most items on a day of the week that includes the $15^{\text {th }}$ of the month, except for fresh foods whose prices are collected three times per month at 10 -day intervals.

Ad hoc surveys are often conducted to obtain information on new and emerging products. A recent survey was undertaken to facilitate the selection of a new sample of flash drives. Such an approach is used when market trends indicate that new product varieties are gaining market prominence. As part of the five-yearly rebasing, surveys are conducted to obtain information on new products for possible inclusion in the new item structure. In several industries affected by deregulation, ad hoc surveys are undertaken to establish new samples.

3.1.2 Source data reasonably approximate the definitions, scope, classifications, valuation, and time of recording required

All source data used for weights and price indicators conform to the definition, scope, classification, valuation, and timing requirements of the PPI. All data relate to domestic market transactions of the selected establishments during the collection period, and are at basic prices.

\subsubsection{Source data are timely}

The source data for weights are received at the time of release by the respective agencies. Information on prices is collected directly by the BOK and is available for index compilation before the end of the reference month.

\subsection{Assessment of source data}

\subsubsection{Source data-including censuses, sample surveys, and administrative records-are} routinely assessed, e.g., for coverage, sample error, response error, and nonsampling error; the results of the assessments are monitored and made available to guide statistical processes

Response rates to the price survey are nearly 100 percent, so there is no problem with non-response. Large price changes are investigated and verified with the respondent to ensure accuracy. BOK price collectors visit the establishments several times during the course of the year to collect a variety of other information. During these visits, they also verify the appropriateness of the specifications and the accuracy of the reported prices.

Industry publications and internet websites of companies are also used to compare price levels and trends for individual products.

The annual manufacturing/mining and agriculture collections are full censuses with complete enumeration and hence sampling errors are not an issue. Response rates are very high. 


\subsection{Statistical techniques}

\subsubsection{Data compilation employs sound statistical techniques to deal with data sources}

Rigorous price editing and querying processes are in place to help ensure the integrity of the PPI.

Temporarily missing prices for both regular and seasonal products are estimated by simply carrying forward the last reported price.

For products that are permanently unavailable, representative replacement products that are similar in quality are selected in consultation with the producers. If there are quality differences between the new and old products, a quality adjustment is made using a range of quality adjustment techniques including changes in production costs and linking with overlapping prices.

For high tech goods, hedonic methods are currently being tested.

New products can enter the market as replacements for disappearing products. In some instances, when they have gained a significant market share and can be accommodated within the index structure, the new products are added to supplement the sample. However, in most instances, new products are only introduced at the time of an index rebase.

\subsubsection{Other statistical procedures (e.g., data adjustments and transformations, and statistical analysis) employ sound statistical techniques}

For each transaction price, the long-term price relative is calculated and the elementary aggregate formed as the simple arithmetic mean of the relevant price relatives, i.e., the Carli formula is used. The BOK recognizes that this formula is known to have a potential upward bias and is not recommended under international standards; accordingly, experimental work is being undertaken on the use of geometric means. The BOK is considering moving to adopting the Jevons formula, which addresses the issue and which would be in line with international best practice. A supplementary index compiled using the geometric mean formula has been compiled from the year 2000 for internal analysis. However, no commitment to adopting the Jevons formula has yet been made or any plans elaborated for involving the users in the decision process. It is planned to undertake a study of the issues associated with the implementation of this methodology for the published index.

The Laspeyres formula is used to aggregate the elementary aggregate indices to progressively higher levels in the index structure. In recognition of the potential for substitution bias using this approach, the BOK has compiled experimental annual chain indices, which would be in line with international best practice, for internal study. With the next index review, consideration will be given to implementing this approach into the mainstream PPI compilation, although no commitment has as yet been made. The BOK considers that there 
may be resource implications, although the current experimental use of the chained index suggests that resource issues have already been addressed.

The weight reference period and the price reference period of the index are aligned, both relating to 2005 . When the 2005 based index was introduced, the previous index (2000 based) was linked to the new index by the application of annual link factors based on the ratio of the 2005 annual average indices calculated using the new weights divided by the indices compiled using the old weights. That is, the previous series was scaled to the levels of the new index in 2005.

\subsection{Assessment and validation of intermediate data and statistical outputs}

\subsubsection{Intermediate results are validated against other information, where applicable}

PPI staff regularly compare PPI and Stage of Processing (SOP) indices with private sector measures (such as raw material price indices) for consistency. Regular analyses of trends between relatable PPI, CPI, import price index and export price index components and aggregates are also undertaken.

\subsubsection{Statistical discrepancies in intermediate data are assessed and investigated}

Unusual movements in the index arising from large movements in particular sectors are investigated and explained in descriptive documentation contained in the monthly press release.

\subsubsection{Statistical discrepancies and other potential indicators of problems in statistical outputs are investigated}

Overall, the PPI and SOP indices are consistent. Consistent imputations, etc., are undertaken in both indices.

\subsection{Revision studies}

\subsubsection{Studies and analyses of revisions are carried out routinely and used internally to inform statistical processes (see also 4.3.3)}

The PPI is final when first released and there are no preliminary monthly estimates.

Every five years, when there is a weight revision (rebase), a study is undertaken to identify the causes of the changes in the weights, new and deleted commodities, changes in coverage, and changes in methodology.

The rebased index is systematically lower than the previous index because of the substitution effects that are prevalent in a fixed weights index. Because of this bias, and the recent international attention that has been given to it, the BOK has commenced compiling an 
experimental annual chain Laspeyres index in order to assess the extent to which the effects of the substitution bias are reduced.

\section{Serviceability}

\subsection{Periodicity and timeliness}

\subsubsection{Periodicity follows dissemination standards}

The PPI is published monthly and conforms to the SDDS requirements.

\subsubsection{Timeliness follows dissemination standards}

The PPI is released around the tenth day after the end of the reference month and the SOP index is released in the middle of the month. The timeliness of both indices conforms to SDDS requirements.

\subsection{Consistency}

\subsubsection{Statistics are consistent within the dataset}

There are two classification typologies for the PPI: a basic classification by industry and a specialized classification by generic commodity groupings (see 2.3.1 above). The aggregate index is invariant to the separate typologies of aggregation.

\subsubsection{Statistics are consistent or reconcilable over a reasonable period of time}

Consistent time series are available for the aggregate PPI back to the last revision in 2005 . Prior to that, there is a consistent historical time series back to 1995, when service industries were introduced, and a consistent series for goods producing industries prior to that date.

Erratic movements in the index, caused for example by unusual shocks such as oil prices, exchange rates or natural disaster, are explained in the monthly press release.

When rebased series are introduced every five years, the PPI is recalculated from the new base period forward and then linked to comparable components of the old series to provide a consistent time series. It is not possible to revise series for methodological changes and source data improvements prior to the last revision.

\subsubsection{Statistics are consistent or reconcilable with those obtained through other data sources and/or statistical frameworks}

Components of the PPI for consumer goods are consistent and relatable with comparable CPI components. The PPIs for raw materials and intermediate goods are consistent with comparable components of the import price index. 


\subsection{Revision policy and practice}

\subsubsection{Revisions follow a regular and transparent schedule}

The PPI is rebased every five years and new weights and a revised regimen introduced. This cycle is well known to users.

The dates of the release of rebased series are announced to the public more than three months in advance. The rebases are scheduled around the availability of weight source data from the censuses and the latest input-output table.

\subsubsection{Preliminary and/or revised data are clearly identified}

This is not applicable as there are no monthly revisions.

\subsubsection{Studies and analyses of revisions are made public (see also 3.5.1)}

No revisions are made to the monthly data. A detailed analysis of the results of the five-year revision is made available at the time of release of the rebased series.

\section{Accessibility}

\subsection{Data accessibility}

\subsubsection{Statistics are presented in a way that facilitates proper interpretation and meaningful comparisons (layout and clarity of text, tables, and charts)}

As well as aggregate indices, time series of PPI statistics are presented at the two- and three-digit industry level of the KSIC in the monthly press release, and also for lower level aggregations (at the five-digit industry level) on the BOK's website. Table layouts are clear, concise and easily readable and the graphs are informative.

\subsubsection{Dissemination media and format are adequate}

The PPI is released around the tenth day of the following month through a press release. Simultaneously, more detailed time series are presented on the BOK's website.

The PPI data on the website are clearly presented with user-friendly menus that readily facilitate the selection of data using a top down approach.

However, the accessibility to ECOS on which the relevant data and metadata are presented at the moment is somewhat problematic. Upon seeking to access ECOS, users are asked to download locally produced software. Reportedly this arrangement derives from a plan of the BOK to speed up access to its data; however, this software is not recognized by users, especially non-Korean users, and institutional firewalls prevent the required downloading or, at a minimum accompany it with strong computer security warnings. In practical terms 
therefore users cannot access these data or their accompanying metadata electronically. (They are still accessible through print publications or commercial vendors.) The BOK is aware of this problem. Budget has been provided, and work will shortly commence on by-passing the need for this software through providing browser-free direct access. It is expected that this work will be completed in 2012.

\subsubsection{Statistics are released on a preannounced schedule}

The release date is announced a week in advance on the website; the date is adhered to.

\subsubsection{Statistics are made available to all users at the same time}

The PPI is made available, in both aggregate and detailed formats, to all users simultaneously. There is no advance release.

\subsubsection{Statistics not routinely disseminated are made available upon request}

Additional non-confidential data are made available on request. Users are advised of this service on the BOK's website.

\subsection{Metadata accessibility}

5.2.1 Documentation on concepts, scope, classifications, basis of recording, data sources, and statistical techniques is available, and differences from internationally accepted standards, guidelines, or good practices are annotated

The BOK publishes a Guide to Economic Statistics, in English and Korean, which covers the methodology used in the PPI. A more detailed description of the concepts, scope, classifications and statistical techniques is provided, in Korean, in the Report on the 2005 Revision on the BOK's website.

Documentation explicitly identifying differences from international standards is not currently produced.

As noted above, there is a significant problem with access to the metadata through ECOS, because of the use of software that is not internationally recognized.

The SDDS metadata and summary methodologies are updated regularly.

\subsubsection{Levels of detail are adapted to the needs of the intended audience}

Summary metadata are presented in the monthly press release and on the website. More detailed and specialized information on the PPI is also presented on the website. 


\subsection{Assistance to users}

\subsubsection{Contact points for each subject field are publicized}

The BOK has a call desk to assist users, staffed by an economist who will either respond directly to enquiries or refer the caller to a subject specialist, as appropriate. In addition, the PPI contact number is on the BOK website.

5.3.2 Catalogs of publications, documents, and other services, including information on any charges, are widely available

The BOK website has a list of publications. In addition, the Economic Information Office can advise users about available publications and services, including charges. 
Table 3. Data Quality Assessment Framework (July 2003): Summary of Results for Price Statistics (Producer Price Index)

(Compiling Agency: Bank of Korea)

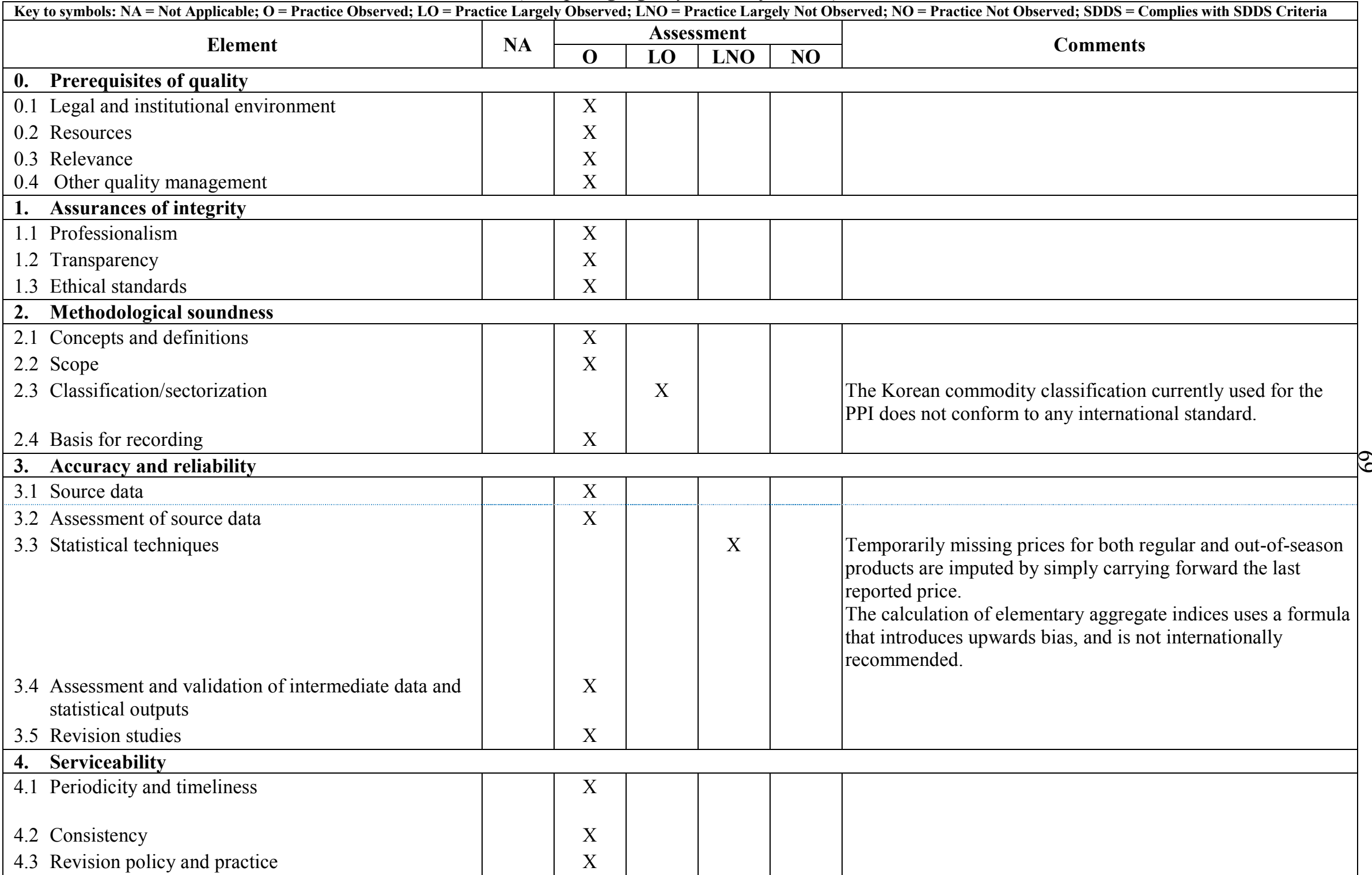


Table 3. Data Quality Assessment Framework (July 2003): Summary of Results for Price Statistics (Producer Price Index)

(Compiling Agency: Bank of Korea)

Key to symbols: NA $=$ Not Applicable; $O=$ Practice Observed; LO $=$ Practice Largely Observed; LNO $=$ Practice Largely Not Observed; NO $=$ Practice Not Observed; SDDS $=$ Complies with SDDS Criteria

\begin{tabular}{|c|c|c|c|c|c|c|}
\hline \multirow{2}{*}{ Element } & \multirow{2}{*}{ NA } & \multicolumn{4}{|c|}{ Assessment } & \multirow{2}{*}{ Comments } \\
\hline & & $\mathbf{O}$ & LO & LNO & NO & \\
\hline \multicolumn{7}{|l|}{ 5. Accessibility } \\
\hline 5.1 Data accessibility & & & $\mathrm{X}$ & & & $\begin{array}{l}\text { There is a significant problem with access to the data through } \\
\text { the ECOS, because of the use of software that is not } \\
\text { internationally recognized. }\end{array}$ \\
\hline 5.2 Metadata accessibility & & $\mathrm{X}$ & & & & \\
\hline 5.3 Assistance to users & & $X$ & & & & \\
\hline
\end{tabular}




\section{Recommendations}

- Implement the Korean Central Product Classification, based on the Central Product Classification, for the 2010 PPI rebase in 2013.

- $\quad$ Introduce the use of more sophisticated techniques for imputing temporarily missing prices for both regular and seasonal products, as described in the PPIM 2004.

- $\quad$ Continue the compilation and study of the Korean supplementary PPI using the geometric mean formula for the computation of elementary aggregate indices. Implement with the 2010 rebase. To the extent that the component products within an elementary aggregate are heterogeneous, with a resultant disparity of price levels, cluster the prices within narrow price bands and form separate elementary aggregates.

- $\quad$ Continue the compilation and study of annual chain Laspeyres PPIs, consult with users during the 2010 rebase and implement with the rebase, to counter the effect of substitution bias.

- In metadata documentation, explicitly identify areas where there are departures from international standards in the Korean PPI. 


\section{Government Finance Statistics}

\section{Prerequisites of quality}

\subsection{Legal and institutional environment}

\subsubsection{The responsibility for collecting, processing, and disseminating the statistics is clearly specified}

The Government Organization Act (1948) and subsequent Decrees attribute to the Fiscal Policies Bureau in the Ministry of Strategy and Finance (MOSF) the responsibility for disseminating statistics on government operations following the internationally accepted definitions and classifications (hereafter referred to GFS).

Three ministries share the responsibility of compiling GFS for sections of the overall government. Pursuant to Articles 9 and 91 of the National Finance Act (2006), the MOSF is responsible for compiling and publishing GFS, as well as statistics on bonds and debt, related to central government. Articles 59 and 60 of the Local Finance Act and Article 67 of the Enforcement Decree of Local Finance Act (2006) stipulate that the Ministry of Public Administration and Security (MOPAS) is responsible for collecting, analyzing, and disseminating GFS for local government. The same legal base confines to the Ministry of Education, Science and Technology (MEST) the duty to collect and compile GFS data for local education institutions. The Ministries cooperate closely to promote consistency of statistical methods and results.

Under the Statistics Law a high-level deliberative body, the National Statistics Committee, has been established under the chairmanship of the Minister for Strategy and Finance for the development and improvement of statistical systems as well as the coordination, merger, and abolition of similar and overlapping statistics.

\subsubsection{Data sharing and coordination among data-producing agencies are adequate}

All central government entities are obliged to report their operations to the MOSF, and all local government entities are obliged to report to the MOPAS. The situation is similar with regard to the MEST. The MOPAS and the MEST in turn provide the statistics for which they are responsible to the MOSF to allow the latter to compile statistics for general government.

Data sharing is deemed to be satisfactory. The compiling ministries consult at least once a year on the production of GFS for general government, as well as on ways to improve this process while reducing the burden on data reporters. These contacts have been taking place on about a monthly basis during the ongoing reform process. 


\subsubsection{Individual reporters' data are to be kept confidential and used for statistical purposes only}

GFS and statistics for government bonds and government debt are subject to the provisions of the Statistics Act. Although the practical implications for GFS are very small, in principle confidential data of individual reporters are protected under Articles 33 and 34 of the Statistics Act.

\subsubsection{Statistical reporting is ensured through legal mandate and/or measures to encourage response}

Pursuant to Articles 9/2, 58/1 and 91/4 of the National Finance Law, the heads of each central government agency shall submit data for the compilation and dissemination of government finance data, preparation of budget settlement statements, and establishment of the government debt management plan to the MOSF. This applies to all units, whether budgetary or extrabudgetary.

Article 59/1 of the Local Finance Law prescribes that the heads of local government agencies shall submit data analyzing the financial management of their agency to the MOPAS. Local education offices should submit similar data on local schools to the MEST.

Adequate reporting of basic data is, among other things, promoted by making reference books available that explain the standards for the submission of information. In addition, the reporting burden for individual government agencies has effectively been eliminated by the introduction of the Digital Budget and Accounting System (DBAS or dBrain). The DBAS has been accompanied by training on how to use the system, the distribution of a manual, and access to a telephone helpline.

\section{$0.2 \quad$ Resources}

\subsubsection{Staff, facilities, computing resources, and financing are commensurate with statistical programs}

Staff, financial, and computing resources are adequate to compile data on central and local government operations. The process of collecting and compiling basic data is fully computerized. Digital budget and accounting systems ensure that the information regarding receipts and payments of government units is instantly processed, which considerably relieves the manual efforts in compiling GFS. The number of staff involved in GFS in the MOSF and the MOPAS together is about 20; the equivalent of about five staff is dedicated to the verification of incoming data.

Staff are adequately trained in applying the recommendations of the Government Finance Statistics Manual 1986 (GFSM 1986). Promotion opportunities and salary increases for these experts are equal to those for other public officials. Sufficient resources have been allocated to maintain the computerized system and additional budget resources have been made available for the project to implement the Government Finance Statistics Manual 2001 (GFSM 2001) that should lead to the publication of a set of new GFS tables in 2012. 


\subsubsection{Measures to ensure efficient use of resources are implemented}

The cost efficiency of the statistical program is monitored. All government agencies are subject to a policy performance assessment conducted by the Prime Minister's Office. For the Budget and Accounting Reinvention Office (BARO), which deals with collecting and compiling source data to produce GFS, the performance indicators include its ability to operate the finance information system in a stable manner and provide information supporting the strategic allocation of government resources. These performance criteria have been assessed annually since 2008 . The results of the performance assessment are used by the administration and the National Assembly when formulating the budget for the following year.

\subsection{Relevance}

\subsubsection{The relevance and practical utility of existing statistics in meeting users' needs are monitored}

The MOSF and the MOPAS maintain several channels to receive information about existing and future users' needs, including through a users' survey conducted in 2007. However, they have not instituted a standing advisory committee.

Feedback received from users, particularly those in government, has for instance led to the high degree of computerization of the compilation process, thus facilitating monitoring key statistics such as details on government spending and debt. The decision to move to accrual accounting and double-entry bookkeeping was also influenced by demands received from outside. More recently, a program was developed to monitor the early execution of government finances in response to the global financial crisis in 2008. This program contributed considerably to the timely design of policies to combat the crisis. User demands are furthermore monitored through reports that IT companies involved in the development of the dBrain system must provide to the MOSF.

With the purpose of improving the quality of GFS, the MOSF instituted in December 2008 a Joint Task Force in which both the government and private sector are represented to reestablish the scope of government. Research regarding policies related to the implementation of the GFSM 2001 is being carried out through co-operation with the Korea Institute of Public Finance. The opinion of other ministries, in addition to expert and researchers' advice, is often asked to review the usefulness of existing statistics and identify those that will be needed in the future.

\subsection{Other quality management.}

\subsubsection{Processes are in place to focus on quality}

The high profile of GFS, which are presented in the National Assembly and used in policy information, reminds managers constantly of the importance of the various dimensions of quality. 


\subsubsection{Processes are in place to monitor the quality of the statistical program}

The BARO monitors the progress in the collection of data and the various tests performed by statisticians on the source data. This results in weekly and monthly business reports.

Every month, the Finance and Planning Division at the MOSF monitors the quality of GFS produced by making comparisons with other statistics. For instance, GFS is compared with the National Tax Service's tax records, other indicators handled by the MOSF (such as major project cost execution records), and statistics for the previous year.

The Statistics Act applies to the GFS. Therefore, under Articles 9 through 12 of the Statistics Act and Articles 7 through 15 of the Enforcement Ordinance of the Statistics Act, the GFS should undergo a quality review every five years, and may in addition be subject to voluntary reviews. Quality reviews were conducted by KOSTAT on the consolidated fiscal balance in 2007, and on government bonds in 2008.

\subsubsection{Processes are in place to deal with quality considerations in planning the statistical program}

Management makes it a matter of policy to respond adequately and in a timely manner to revealed needs, thereby improving existing statistics and developing new ones. Specifically, this led to the development of a program to ensure timely monitoring of the execution of the budget, which has been one of the tools supporting measures to maintain economic stability during the 2008-9 global economic turmoil. Since the reorganization of the government (March 2008) efforts have been made also to provide explanations on the consolidated budget balance. These explanations are scheduled to be provided on the official websites during 2010.

\section{Assurances of integrity}

\subsection{Professionalism}

\subsubsection{Statistics are produced on an impartial basis}

There is no formal arrangement that supports professional independence. However, strong informal safeguards support professional independence of both the compiling unit and the compilation process. Staff make their own decisions with respect to data compilation based on objective facts and the recommendations of international manuals. They accept no interference from outside and are strongly supported in this respect by the MOSF management.

Staff recruitment is based on a relevant specialty, which may be statistics, economics, or accounting. Staff participate in workshops and training courses organized by regional and international organizations (e.g., the OECD and the IMF). Use is made of the ability of the commissioner of KOSTAT to support education programs on statistics, exchanges and cooperation with international organizations, foreign governments, and foreign institutions. 
Staff make contributions to an annual description of the GFS system in the annual publication Government Finance Statistics of Korea.

\subsubsection{Choices of sources and statistical techniques as well as decisions about dissemination are informed solely by statistical considerations}

Decision on sources, statistical methods, and channels of dissemination are made exclusively based on professional considerations. As GFS and statistics on government debt are submitted to the National Assembly, factors other than accuracy, objectivity, and credibility are not taken in consideration.

\subsubsection{The appropriate statistical entity is entitled to comment on erroneous interpretation and misuse of statistics}

The MOSF actively comments on misinterpretation or misuse of GFS by the National Assembly, the media, academia, research institutes, or NGOs. This generally is done through a press release, which also is posted on the MOSF website (http://english.mosf.go.kr, News and Events). In the case of erroneous interpretation by the National Assembly, comments may be delivered in the form of review report, or officials may explain the data when the National Assembly questions ministers during the regular plenary session.

To prevent misinterpretation or misuse of statistics, the Public Relations Division in the MOSF reviews the media every day.

\subsection{Transparency}

\subsubsection{The terms and conditions under which statistics are collected, processed, and disseminated are available to the public}

All Acts and Presidential and Ministerial Decrees are published in the Kwanbo (the Government Gazette) and posted on the websites of the relevant Ministries. Laws and regulations are also available in public libraries served by computerized search facilities and universities. The Government Accounting Settlement Guidelines are published and are equally easily accessible.

\subsubsection{Internal governmental access to statistics prior to their release is publicly identified}

There is no internal government access to statistics prior to their release. Officials are not aware of any recent attempt by other government bodies to obtain early access. The publication of monthly GFS data is approved by the Director General of the Fiscal Policy Bureau in MOSF; and the publication of the annual data is approved by the Minister of the MOSF. The approval process is made public through a Delegation Decree.

\subsubsection{Products of statistical agencies/units are clearly identified as such}

The information on GFS is identified by source. Statistics disseminated in the form of a press release include the name of the data-producing agency, as well as the agency's logo, emblem, 
and contact information of the staff member in charge. Statistics released in other forms equally clearly identify their source.

\subsubsection{Advance notice is given of major changes in methodology, source data, and statistical techniques}

Up to now there have not been major changes in source data, methodology, or statistical techniques. When major changes are introduced, such as the implementation of GFSM 2001, the MOSF intends to provide adequate advance notice and background to the public.

\subsection{Ethical standards}

\subsubsection{Guidelines for staff behavior are in place and are well known to the staff}

All public officials are bound by the rules outlined in the Code of Ethics for Civil Servants. This code specifies, inter alia, an obligation of loyalty to the State, honesty and service to the people, and professional and personal integrity.

In addition, MOSF staff are bound by a specific code of conduct. This code specifies, among other things, an obligation to fair performance of official duties, and provides guidelines for staff behavior when higher officials order duties in contravention of fairness, or when unreasonable demands are made by a politician or a political party. The code also addresses staff's responsibility to avoid duties in which they may have a personal interest, and to abstain from giving special favors, or making use of information obtained during the course of performing official duties. Penalties are applied to noncompliant staff.

All MOSF staff recognize the code of conduct. They are educated in various ways: detailed information and Q\&A documents are made available, and staff are reminded periodically of the code by way of workshops organized for all MOSF employees. Furthermore, new staff and officials transferred from other ministries are educated on the code of conduct when they join the organization. This cultural environment promotes that all MOSF officials, from the minister to new staff, strictly observe the code.

\section{Methodological soundness}

\subsection{Concepts and definitions}

\subsubsection{The overall structure in terms of concepts and definitions follows internationally accepted standards, guidelines, or good practices}

The overall structure of the Korean GFS follows the concepts and definitions of the GFSM 1986. The authorities have been working on a major restructuring of their budget process that will allow them to disseminate GFS according to the GFSM 2001 within a few years.

The restructuring process is making good progress and has involved, among other things, the adoption of a comprehensive new dBrain and the introduction of new government accounting 
standards. All local government units with the exception of (most) education entities introduced accrual accounting and double-entry book keeping in January 2007; the remaining education entities followed suit in January 2009 (cash-based data will continue to be available). Furthermore, in December 2008 a task force was instituted to review the scope of government, which, following the recommendations of the GFSM 2001, should be based on institutional units. The full revision process has been accompanied by advice from external experts and research institutes, including the Korean Institute of Public Finance.

GFSM 2001 compliant statistics are expected to be published in 2012 after a trial period. They should encompass the full range of operations and balance-sheet tables recommended by the Manual.

It should be noted that the GFS compiling Ministries also publish budget execution data in the shape of Budget Settlement Statements. The structure of these Statements differs in various respects from the GFS. When the structuring process has been completed, however, the budget statements will have approximately the same format as the GFSM 2001 statistical tables.

\section{$2.2 \quad$ Scope}

2.2.1 The scope is broadly consistent with internationally accepted standards, guidelines, or good practices

The government sector in Korea's GFS covers all entities performing a government function. This is in accordance with the definition of the GFSM 1986, which differs from the recommendations in the $1993 S N A$. The information is detailed by the central and local government levels. In addition, data on nonfinancial public enterprises (NFPEs) are published in GFS format.

\subsection{Classification/sectorization}

\subsubsection{Classification/sectorization systems used are broadly consistent with internationally accepted standards, guidelines, or good practices (*)}

The Korean GFS distinguish between central and local government in accordance with the recommendations of the GFSM 1986.

From an administrative point of view, the central government and local government each comprise general budget accounts, special accounts, and public funds. Central government also includes extra-budgetary accounts and off-budget items, while local government includes the special accounts for local education.

The general account covers general expenditures financed by general tax revenue. Special accounts are used to manage funds raised from specific sources that are spent on selected purposes. They are subdivided according to their purposes into (i) special accounts to finance specific programs-these accounts are financed by the operating income of the respective 
nonfinancial public enterprises (NFPEs) and by transfers from the general account; (ii) special accounts established for managing special funds-e.g., the Fiscal Financing Special Account, which is financed from income from government property and surpluses from other public funds; and (iii) special accounts for expenditures financed with earmarked revenues. The GFS exclude special accounts that are mainly involved in commercial activities (the NFPEs) or have monetary/financial functions. Also excluded is the Foreign Exchange Stabilization Fund, which is considered a constituent part of the monetary authorities accounts in consistency with the recommendations of the GFSM 1986 (see however section 4.2.1). Extra-budgetary funds are funds owned by the government whose operations are viewed as important to the pursuit of government policy objectives. They are included in the budget documents but are not technically part of the budget proper (the branch ministries or agencies have a wider discretion over the use of the extra-budgetary funds they manage). GFS data cover social security funds. Off-budget items are small or temporary accounts that usually have no positive or negative balance. An example is the Foreign Sub-loans account that records loans taken up abroad by central government that are lent on to local governments. The following box summarizes the types of administrative units that are included in the central government and local government subsectors.

\section{Box 1. Composition of the central and local government sectors}

Central government includes:

- $\quad$ Budgetary central government, that is, the general account covering the Presidency, Prime Minister's office, National Assembly, Judiciary, ministries, national election commission;

- $\quad$ Extra-budgetary central government, comprised of

- the special accounts other than those of entities engaged in large-scale commercial activities, and social security funds;

- public funds excluding funds with monetary and financial functions; and

- off-budget items such as the account for foreign sub-loans;

- $\quad$ Social security funds, comprising the National Pension Fund, the Employment Insurance Fund, and the Industrial Accident Compensation Insurance and Prevention Fund.

In addition, data for the five central government special accounts that refer to nonfinancial public enterprises are compiled and published in GFS format.

Local government includes:

- The general accounts

- Special accounts

- $\quad$ Public funds.

for the following entities:

- $\quad$ The city of Seoul, six other autonomous cities, nine provinces (Do);

- $\quad 74$ cities ( $\mathrm{Si}$ ), 89 counties (Gun), 69 autonomous districts (Jachi-Gun)

- $\quad$ Local education institutions.

Data on small entities such as nonautonomous districts (Gu), Dongs, and Meyons are included in the data reported by the larger local government entities. 
The economic and functional classifications used in the Korean GFS are consistent with the GFSM 1986. Data on lending minus repayments include changes in equity and are presented on a gross and net basis. Privatization receipts are classified under lending minus repayments (net lending and net acquisition of equities).

\subsection{Basis for recording}

\subsubsection{Market prices are used to value flows and stocks}

All flows are recorded at the value of the cash received or paid. Transactions in foreign currency are converted to local currency using the mid-point exchange rate prevailing in the market at the moment they take place. Debt outstanding is valued at face value (the amount that the government is obligated to pay when the debt matures). Debt denominated in foreign currencies is valued at appropriate foreign exchange rates as at the end of each period. The difference between value on maturity of discounted bonds and their issue or acquisition price is recorded as interest. These practices are consistent with the GFSM 1986 recommendations.

\subsubsection{Recording is done on an accrual basis}

In accordance with the GFSM 1986, transactions are recorded on a cash basis, that is, when cash is received (revenue) and paid (expenditure). Even though parts of government have already adopted accrual accounting, the GFS are compiled on a cash basis. This is made possible by the fact that all stages between the budget preparation and the final payments related to the budget realization are covered by appropriate documentation.

Payments recorded during the first 15 days of the fiscal year are allocated to the previous year.

\subsubsection{Grossing/netting procedures are broadly consistent with internationally accepted standards, guidelines, or good practices}

All transactions are shown on a gross basis. Tax refunds are shown as negative tax revenue. Borrowing and amortization are shown on both a gross and a net basis. The (net) cash operating surpluses or deficits of NFPEs are recorded as revenue or expenditure respectively. Intergovernmental transfers can be clearly identified and are eliminated from the appropriate expenditure and revenue items when the accounts are consolidated. These practices are in accordance with the recommendations of the GFSM 1986. 


\section{Accuracy and reliability}

\subsection{Source data}

\subsubsection{Source data are obtained from comprehensive data collection programs that take into account country-specific conditions}

The sources for the Korean GFS transaction tables are all administrative records obtained from budget execution data. The budget codes used by central government, local government, and local education agencies, although different from each other, all include identifiers that recognize the economic, functional, and transaction partner classifications of payments received or made. Extra-budgetary accounts use the same coding system that is used in the budgetary accounts. Sources for the central government debt tables are the submissions that all central government agencies have to make to the MOSF.

The data collection is strongly computerized. In central government, the Digital Budget and Accounting System (dBrain) has been in use since 2007. dBrain is an integrated fiscal information system that covers all fiscal affairs including budget formulation, execution, and settlement, management of state assets and debt on an online and real time basis. Apart from agencies that still operate their own systems (the Ministry of Unification, Korea Post, and some public funds), dBrain is being used by all central government agencies. Information from the agencies not using dBrain is collected either through a real-time connection with dBrain, or by periodic uploading on the dBrain website.

Systems like dBrain make sampling or collecting information from supplementary sources superfluous. With the help of a bridge table, the program even automatically produces statistical tables. The MOPAS uses a similar system called e-Hojo, and the MEST makes use of the system Edufine.

\subsubsection{Source data reasonably approximate the definitions, scope, classifications, valuation, and time of recording required}

Detailed source data for the central government and local government are fully reconcilable with the GFS definitions and classification system. However, the source data the MEST collects from schools provide few details.

The time of recording and valuation of source data are consistent with the recommendations of the GFSM 1986.

\subsubsection{Source data are timely.}

Source data on government operations are available on a timely basis. In the Digital Budget and Accounting Systems, entries are recorded when transactions are made based through the Electronic Bill Presentation and Payment and the Electronic Funds Transfer. Agencies that are not permanently linked to the mainframe upload their information regularly (at least every month). 


\subsection{Assessment of source data}

3.2.1 Source data-including censuses, sample surveys and administrative records—are routinely assessed, e.g., for coverage, sample error, response error, and other nonsampling error; the results of the assessments are monitored and guide statistical processes

The information that is uploaded in the Digital Budget and Accounting Systems is assessed on a daily basis at the responsible ministries. The systems also themselves perform automated tests on the inputted data.

\subsection{Statistical techniques}

\subsubsection{Data compilation employs sound statistical techniques to deal with data sources}

Apart from several validation rounds, there is no need for statistical techniques. As the sources are complete and available on time, no estimates are made for missing data. The automated systems compile statistics through simple addition.

\subsubsection{Other statistical procedures (e.g., data adjustments and transformations, and statistical analysis) employ sound statistical techniques}

An essential procedure needed is the development of sound bridge tables between the source data classified by budget categories and the GFSM 1986 classifications.

\subsection{Assessment and validation of intermediate data and statistical outputs}

\subsubsection{Intermediate results are validated against other information where applicable}

Statistical discrepancies are rare owing to the detailed monthly reconciliation undertaken and the automatic cross-checks imbedded in the data compilation system.

A monthly comparison is made with the data recorded by the BOK (in the case of central government), or the designated regional bank (in the case of local governments). Comparisons are made with revenue data from the tax service and other administrative sources, such as on the progress of major projects. Also, intermediate results are evaluated against data pertaining to the same period in the previous year.

\subsubsection{Statistical discrepancies in intermediate data are assessed and investigated.}

Statistical discrepancies are investigated and solved.

\subsubsection{Statistical discrepancies and other potential indicators of problems in statistical outputs are investigated}

Statistical discrepancies are rare and mostly do not allow drawing general conclusions about types of errors that should be monitored more closely. 


\subsection{Revision studies}

3.5.1 Studies and analyses of revisions are carried out routinely and used internally to inform statistical processes (see also 4.3.3)

Revisions of the data are incidental and limited in scope. They do not give rise to studies into systematic errors or omissions.

\section{Serviceability}

\subsection{Periodicity and timeliness}

\subsubsection{Periodicity follows dissemination standards}

The GFS detailed data for the central government are disseminated on a monthly basis, and data for the general government are disseminated on an annual basis. Quarterly debt data for the central government are posted on the KOSTAT website.

The periodicity of these data is consistent with SDDS requirements.

\subsubsection{Timeliness follows dissemination standards}

Monthly GFS data for the central government are generally disseminated within one month after the reference period. Data for the first months of the fiscal year may take slightly longer due to work pressures associated with the closing of the preceding fiscal year. This is a small infringement on SDDS requirements.

GFS on the general government are disseminated usually about one year after the end of the reporting year. Good practice as laid down in the SDDS requirements indicates that these data should be published within two quarters after the reporting year. Korea is availing itself of a flexibility option regarding the timeliness of general government operations data.

Quarterly statistics for central government debt are disseminated within one quarter. This corresponds with SDDS requirements.

\subsection{Consistency}

\subsubsection{Statistics are consistent within the dataset}

Statistics are mostly internally consistent. Components of revenue, expenditure, net lending, and financing add to aggregates. Detailed revenue, expenditure and net lending, and financing data agree with the aggregates in summary table. Substantial internal cross-checks aimed at ensuring the internal consistency of the fiscal accounts are embedded in the digital fiscal accounting systems in use by the three GFS compiling ministries. 
However, the definition of government in the debt tables is not equal to the one in the operations tables. Contract authorizations are not included in the operation tables, but they are recorded as part of government debt. (Contract authorizations refer to unpaid government debt that has been converted into fixed-term contractual obligations. They are a minor element of debt). Also, in line with the recommendations of the GFSM 1986, the Foreign Exchange Stabilization Fund is excluded from the operations tables. Nevertheless, in response to the requirements of the National Finance Act, bonds issued by this Fund are included in the outstanding debt of central government. These inconsistencies will be removed when the data are published according to the GFSM 2001.

\subsubsection{Statistics are consistent or reconcilable over a reasonable period of time}

There are no significant breaks in series over a reasonable period of time.

The MOSF adheres to the principle that when changes in statistics or methodology are introduced, historical series should be reconstructed as far back as reasonably as possible. Recently, as the GDP data were changed by adopting new base year in the national accounts, the MOSF reconstructed relevant ratios, and these changes were explained in the commentary. In general, unusual changes in trends are explained in the MOSF press releases.

\subsubsection{Statistics are consistent or reconcilable with those obtained through other data sources and/or statistical frameworks}

The overall budgetary position according to GFS used not to coincide with the corresponding item that the BOK published till 2001 owing to differences in institutional and transactions coverage between the two datasets. GFS data include net foreign borrowing on-lent to enterprises not included in the BOK's government data. Moreover, the BOK classified cash in the Treasury (government cash) as a government deposit in the BOK thus affecting the measure of net credit to the government. Despite these differences, the two statistics were still fully reconcilable as the source data of the BOK coincided with those of used for the compilation of GFS.

Nowadays, the GFS are in principle reconcilable with the balance of payments and the national accounts. Whereas the GFS is based on cash data provided by the government administrative system, the balance of payments and the national accounts compilers (when describing government operations) use accrual base information emerging from the same source.

Financial statistics classify three unfunded government employee pension schemes in the subsector Other financial institutions, whereas the GFS classify them in central government. Again, reconciliation of the two statistics is possible. 


\subsection{Revision policy and practice}

\subsubsection{Revisions follow a regular and transparent schedule}

Once the National Assembly has reviewed the budget account settlement, the GFS data including the fiscal balance and government debt are considered final. Minor revisions to monthly data are incorporated in the monthly cumulative data disseminated for the following month(s).

There is no schedule to conduct major revisions, given that data are sourced from actual administrative files.

\subsubsection{Preliminary and/or revised data are clearly identified}

Preliminary data are clearly indicated as such in the publications, either as a note in the statistical tables or as a general warning in the accompanying text.

\subsubsection{Studies and analyses of revisions are made public (see also 3.5.1)}

Press releases and several other publications contain an explanation of revisions.

\section{Accessibility}

\subsection{Data accessibility}

\subsubsection{Statistics are presented in a way that facilitates proper interpretation and meaningful comparisons (layout and clarity of text, tables, and charts)}

The three annual press releases related to GFS (related to the annual general government data, the publication of Government Finance Statistics of Korea, and the release of summary data on the operations of local government) answer the criteria of clear textual and analytical presentation, understandable tables providing time series if appropriate, and charts conducive to the correct interpretation of the data.

\subsubsection{Dissemination media and format are adequate}

A problem is that the information on GFS is dispersed over several partial publications that, even when taken together, does not provide a complete picture. To remedy that situation, the MOSF has recently taken the initiative of developing a website that draws together comprehensive information on the Korean GFS (see http://english.mosf.go.kr/public/gfs list.php?sect=pubs the Korean version is more extensive, see http://www.digitalbrain.go.kr/ifms/hp/sa/SaItgPfinRad.do. The website should present, among other things, the detailed operation accounts for general government and its subsectors, as well as the debt data of central government (the latter are already available on the Korean language website at http://www.digitalbrain.go.kr/ifms/hp/sa/SaGod.do).

\subsubsection{Statistics are released on a preannounced schedule}


With the exception of statistics published on the National Summary Data Page, no preannounced schedules exist. Nevertheless, many users know approximately when the data will be released. For instance, for central government the monthly data are disseminated about one month after the reference period; the preliminary data on the annual budget execution are published in March, and the final data are disseminated immediately after the National Assembly has approved them. Users can sign up for being alerted when the data are posted.

\subsubsection{Statistics are made available to all users at the same time}

The statistics are made available to interested users at the same time. In the past, press releases were provided to the media under embargo. This practice has been discontinued.

Box 2 contains an overview of the various GFS publications and their main characteristics.

\begin{tabular}{|c|c|c|}
\hline \multicolumn{3}{|c|}{ Box 2. Dissemination vehicles of Korea's GFS } \\
\hline \multicolumn{3}{|c|}{ General Government } \\
\hline \multirow[t]{3}{*}{ Annual } & $\begin{array}{l}\text { Operations and debt } \\
\text { (in development) }\end{array}$ & $\begin{array}{l}\text { Detailed data, broken down by subsectors. MOSF website, in Korean } \\
\text { and English. Will be further developed to become the central } \\
\text { dissemination vehicle of Korean GFS. }\end{array}$ \\
\hline & Operations & $\begin{array}{l}\text { Summary data, no text. KOSTAT website DSBB/NSDP, in Korean } \\
\text { and English. (Methodological notes on the IMF DSBB website). }\end{array}$ \\
\hline & Operations & $\begin{array}{l}\text { Press release providing an analysis of the summary data, available on } \\
\text { the MOSF website, in Korean. }\end{array}$ \\
\hline \multicolumn{3}{|c|}{ Central Government } \\
\hline \multirow[t]{2}{*}{ Monthly } & Operations summary & Cumulative data with some metadata. MOSF website, in Korean. \\
\hline & Operations summary & $\begin{array}{l}\text { Cumulative data, no text. KOSTAT website DSBB/NSDP, in Korean } \\
\text { and English. (Methodological notes on the IMF DSBB website). }\end{array}$ \\
\hline Quarterly & Debt & $\begin{array}{l}\text { No text. KOSTAT website DSBB/NSDP, in Korean and English. } \\
\text { (Methodological notes on the IMF DSBB website). }\end{array}$ \\
\hline \multirow[t]{2}{*}{ Annual } & Operations & $\begin{array}{l}\text { Government Finance Statistics of Korea, hard copy and press release } \\
\text { by the MOSF (the latter also on the MOSF website), in Korean with } \\
\text { English labels in the tables. Tables of full central government and } \\
\text { PSEs' operations with extensive methodological explanations. }\end{array}$ \\
\hline & Debt & $\begin{array}{l}\text { Report on Government Debt Management and Government Debt } \\
\text { Management Plan, hard copy, data and extensive press release also } \\
\text { available on the MOSF website in Korean and English. Detailed } \\
\text { tables on various aspects of debt, methodological notes, and analysis. }\end{array}$ \\
\hline \multicolumn{3}{|c|}{ Local Government } \\
\hline Annual & $\begin{array}{l}\text { Operations and } \\
\text { balance sheet } \\
\text { summary }\end{array}$ & $\begin{array}{l}\text { Tables and press release on the MOPAS website, in Korean. Accrual- } \\
\text { based data. Budget execution data rather than GFS. }\end{array}$ \\
\hline \multicolumn{3}{|c|}{ Local Education } \\
\hline & Not applicable & Currently no publication of data or metadata. \\
\hline
\end{tabular}

DSBB/NSDP: Dissemination Standards Bulletin Board, National Summary Data Page. 


\subsubsection{Statistics not routinely disseminated are made available upon request}

At their request, users can obtain data that are more detailed than those appearing in the publications.

\subsection{Metadata accessibility}

5.2.1 Documentation on concepts, scope, classifications, basis of recording, data sources, and statistical techniques is available, and differences from internationally accepted standards, guidelines, or good practices are annotated

The Government Finance Statistics of Korea, Report on Government Debt Management and Government Debt Management Plan, and the Financial Yearbook of Local Government provide information on concepts and methods. For instance, the Government Finance Statistics of Korea contains a discussion of concepts and definitions, and explains the link between revenue and expenditure items in the budget documents and the GFS. These metadata, however, refer to specific levels of government and are in part difficult to access by users.

Users that would like to have a general overview of the Korean GFS concepts and methods can turn to the DSBB metadata posted on the IMF's website. Some metadata are provided in the Government Finance Statistics of Korea such as on the concepts and definitions of GFS, compilation, processing, and the relationship with the budget.

\subsubsection{Levels of detail are adapted to the needs of the intended audience}

The monthly publication of central government operations on the MOSF website provides suitable concise metadata touching on the concept of GFS and its history, the scope of the data, classifications, etc. Lay users who want to have a general overview that still is not too voluminous are best served by the metadata developed in the framework of the DSBB. Audiences that are interested in further details probably would like to go deeper into the concepts used in government budgets. On this topic, publications are available at various levels of sophistication. A simple introduction provides the annual MOSF publication Budget Overview, also available at the MOSF website, which is distributed when the budget is submitted to the National Assembly. The Budget Overview includes an explanation of the difference between the concepts of "revenue" and "expenditure" in the budget document and in the GFS.

\subsection{Assistance to users}

\subsubsection{Contact points for each subject field are publicized}

The names of relevant staff are indicated in the GFS publications and press releases. 
The Guideline for Civil Affairs Management requires that requests for data must be followed up within seven days. The timely response on inquiries is one of the indicators for evaluating the MOSF's performance, and thus is closely monitored.

5.3.2 Catalogs of publications, documents, and other services, including information on any charges, are widely available

A short catalog of GFS publications is available (see

http://www.digitalbrain.go.kr/ifms/hp/sa/help/SaFiItgPfinTsiRepMtrP.htm in Korean). 
Table 4. Data Quality Assessment Framework (July 2003): Summary of Results for Government Finance Statistics (Compiling Agency: Ministry of Strategy and Finance (MOSF))

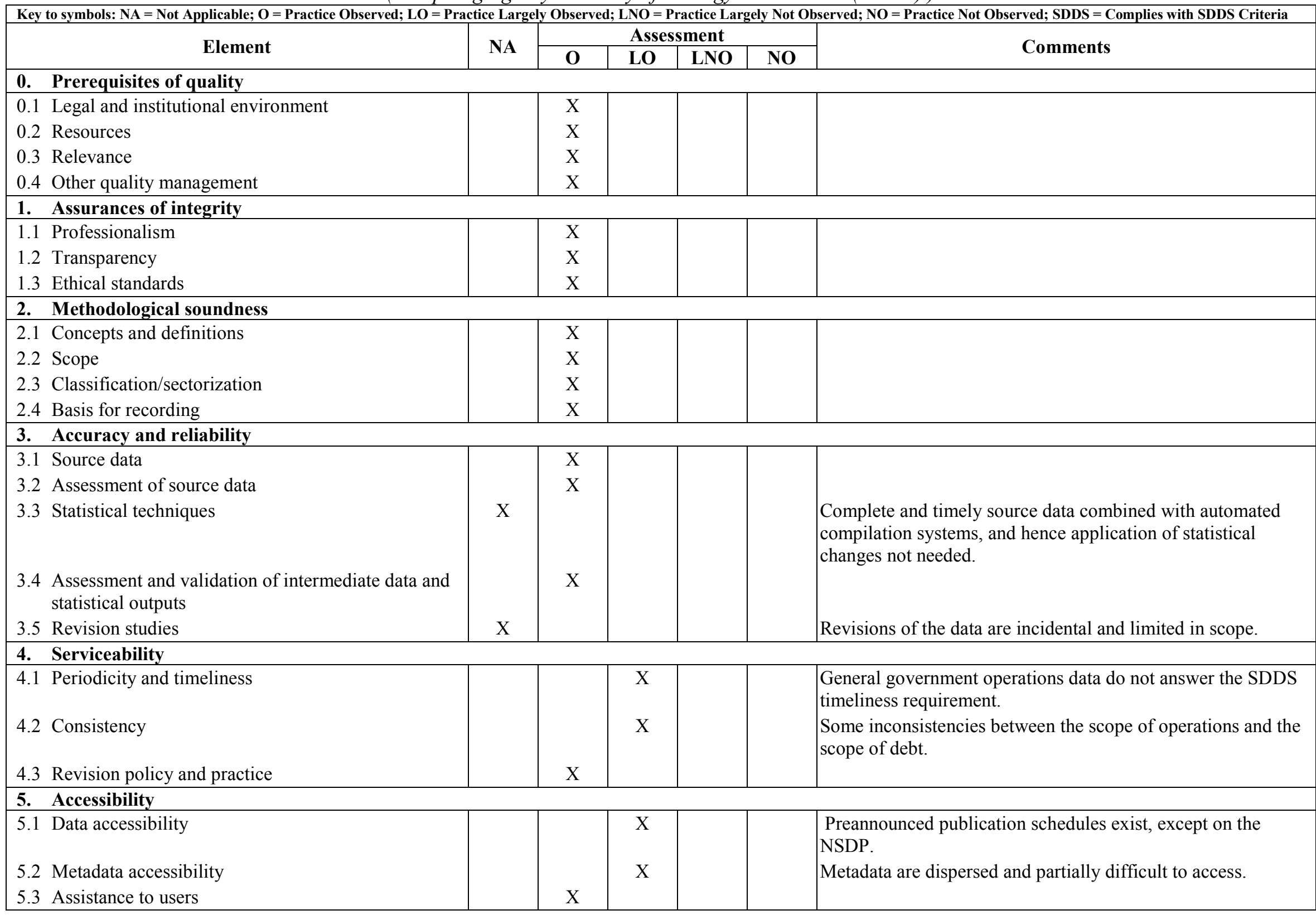




\section{Recommendations}

\section{High priority}

- $\quad$ Review range of publications of data and metadata for general government and its subsectors with a view to increasing focus on, and accessibility of, data on the government sector as a whole.

- $\quad$ Strive to make a detailed description of sources and methods of the compilation of Korean GFS available to users (in Korean and English).

- $\quad$ Study the possibilities to publish the general government operations data within the timeliness prescribed by the SDDS (and thus relinquish the current flexibility option).

- Footnote in all publications of government debt that, in contrast to the functional definition of government in the operations accounts, the central government debt data also include bonds issued by the FESF. Furthermore, involve the BOK and KOSTAT in the discussions how to make the GFSM 2001 definition of government operational in Korea. Consider classifying the FESF into the accounts of the central government at the time of the GFSM 2001 migration, in line with the precepts of that manual.

\section{Other recommendations}

- $\quad$ Strictly adhere to SDDS timeliness for GFS data on the NSDP.

- Introduce an advance release calendar for all Korean GFS publications.

- $\quad$ Publish monthly central government operations data as distinct months instead of the cumulative figures for the current year. This facilitates the analysis of trends by allocating any revision on the original data to the correct months.

- $\quad$ Periodically compare the GFS with the government data in the balance of payments, the national accounts, and monetary statistics. 


\section{Monetary Statistics}

\section{Prerequisites of quality}

\subsection{Legal and institutional environment}

\subsubsection{The responsibility for collecting, processing, and disseminating the statistics is clearly specified}

The Bank of Korea (BOK) has the responsibility for collecting source data, and compiling and disseminating monetary statistics. The Bank of Korea Act (last amended in 2008) assigns the responsibility and provides authority to the BOK for collecting and compiling macroeconomic statistics, including monetary statistics. Article 86 of the Act states that "The Bank of Korea may, when necessary for the formulation of its monetary and credit policies, collect and compile statistics on money and banking, public finances, prices, wages, production, the balance of payments, and other basic economic statistical series and conduct economic research and for such purposes request any materials or information from government organizations and any juristic or individual person."

Article 42 of the Banking Act states the terms under which commercial and specialized banks are to submit balance-sheet accounts to the BOK and that the BOK may publish the reported data. Although the Banking Act relates only to financial institutions maintaining reserves requirements with the $\mathrm{BOK}$, other financial institutions incurring liabilities that are included in Korea's broad money aggregate, M2, file monthly balance sheet returns requested by the BOK.

In addition, the Statistics Act (last amended in 2009) specifies all aspects of the production of statistics in Korea. Article 15 describes conditions for the designation of designated statistics-collecting agencies; and Article 18 governs conditions for the collection and dissemination of statistics. As a designated agency the BOK is governed in its statistical work also by the remaining provisions of the Statistics Act. Article 27 requires statistical agencies, including the BOK, to disseminate the macroeconomic statistics compiled and their corresponding metadata.

Within the BOK, the Monetary and Financial Statistics Team (MFST) of the Economic Statistics Department (ESD) is responsible for collecting source data, and compiling and disseminating monetary statistics. Working arrangements in the BOK for the collection and compilation of monetary data are consistent with the assignment of responsibilities granted by the corresponding legal framework.

\subsubsection{Data sharing and coordination among data-producing agencies are adequate}

Under the Statistics Act, a high-level deliberative body, the National Statistics Committee, has been established under the chairmanship of the Minister of Strategy and Finance, for the development and improvement of statistical systems as well as the creation, merger and abolition of similar and overlapping statistics. 
The Statistics Act ensures coordination and data sharing among statistics-compiling agencies. Article 30 of the Statistics Act states that "In cases where it is necessary for the collection of statistics, the head of a statistics-collecting agency may request other statistics collecting agencies for the supply of statistical data. In such cases, the head of a statistics collecting agency who has received the request shall comply therewith unless there is any special reason otherwise."

Although monetary statistics from compilation to dissemination are the responsibility of the BOK, there is a need for data cross-checking with the Financial Supervisory Service (FSS) and data adjustment based on the Korea Securities Depository's (KSD) database. The working arrangements between the BOK and these agencies are adequate (see item 0.2.1 ahead).

\subsubsection{Individual reporters' data are to be kept confidential and used for statistical purposes only}

The Statistics Act, in Article 33, states that data collection and compilation by the statistical agencies must carry a legal guarantee of protection of the confidentiality of individuals and juristic persons or bodies' information; and the information collected will be used only for statistical purposes. Article 39 states that persons who use data for other than statistical purpose or disclose to others are subject to imprisonment for not more than three years or a fine of not more than ten million Korean won.

All BOK staff are bound by the Bank of Korea Act, Article 42, which specifies that they should not divulge confidential matters to outsiders. Similar provisions are contained in Article 20 of the Articles of Incorporation of the BOK, as well as in the BOK's Rules of Employment, the Code of Conduct, and the Code of Ethics and Morals. All staff must take a written oath to commit to follow the Code of Conduct, and penalties and sanctions are provided for not doing so.

The Guidelines for Compilation and Dissemination of Statistics of the ESD, in its Article 2, states that the employees of the ESD shall protect the collected basic data from unlawful disclosure and that confidential information of data providers should not be allowed for public reading, reprint, or dissemination to those other than the statistics compilers. Also, the confidentiality of data is guaranteed by the following: (i) access to confidential data is restricted to staff directly involved; (ii) access to the BOK building and respective offices is restricted; and (iii) computer and database security is ensured. New staff, including temporary staff, are apprised of the guidelines.

The integrity of the staff is held to be of critical importance at the highest levels of the BOK. Any breach of confidentiality would likely be reported in detail in the newspapers; to date, there have been no such breaches. Under the Statistics Act, Article 39, breaches of confidentiality may result in imprisonment. 
Other depository corporations (ODCs) report data electronically via the BOK's Data Collection System (DACOS; http://dacos.bok.or.kr) through the internet. No specific security measures are in place to protect the reported data from external attacks, but the data are in coded format. Also, the Information Technology Department of the BOK audits and monitors the traffic between the BOK network and the internet through the Intrusion Prevention System. If unauthorized intrusions are detected, the Integrated Security Control System would block the respective computer or server. The BOK requests a private IT security firm to conduct annual evaluations of its IT security systems.

\subsubsection{Statistical reporting is ensured through legal mandate and/or measures to encourage response}

The BOK has the legal authority to collect data required to compile monetary statistics, and its collection activity is consistent with the legal authority. The Bank of Korea Act, the Banking Act, and the Statistics Act collectively provide the legal basis for the collection of statistical information for compiling monetary statistics. The Banking Act specifies the format and timeliness with which the financial institutions should report to the BOK.

However, the BOK has no legal power itself to impose penalties for non-compliance with statistical reporting requirements. Under the Statistics Act, Article 41, (KOSTAT can impose fines for non-response to reasonable requests. The BOK can ask KOSTAT to levy such penalties on its behalf, but so far has never needed to do so. In practice, the BOK emphasizes courtesy and effective relations with data reporters, explains the importance of the data being sought for policy analysis and formulation, and provides assistance in completing and submitting reporting forms.

\section{$0.2 \quad$ Resources}

\subsubsection{Staff, facilities, computing resources, and financing are commensurate with statistical programs}

Staff, facilities, and computing resources are fully adequate to compile monetary statistics. The MFST comprises 13 professional staff with experience in the compilation of monetary statistics ranging from 10 months, for the most recently appointed employee, to over seven years for several key staff. The team consists of a head, five economists, and seven assistant economists. All professional staff have completed a university education - two staff members have doctor's degrees in economics and in statistics, one has a master's degree in economics, and all the other staff members have bachelor's degrees in economics and in business administration.

The BOK takes every opportunity to send staff on international training courses, seminars, and workshops. A separate budget is available to the ESD for these purposes. Two staff members have participated in the IMF's Monetary and Financial Statistics training courses. Most knowledge of compilation is built up from the job manuals which explain the concepts, classification, compilation process, and computer programming. These manuals are regularly updated by each current compiler to reflect any changes in the compilation process and handed over to new compilers with explanation and coaching. New staff is always provided 
on-the-job training for about one month. The BOK also undertakes its own training in general statistical matters, including monetary statistics. Salaries are competitive in the BOK, so it does not have a serious issue in retaining staff or obtaining funding for statistical development.

Available computer and other IT resources are adequate to perform the required tasks. Each staff member has a computer. Computers are linked by a local network within the ESD and with other departments of the BOK. An exclusive network line is also available for accessing the database of the KSD and the BOK wire system that is used for payments within the financial system of Korea. The MFST staff have access through the internet to the database of the FSS for relevant balance sheet data.

The MFST compiles statistics using the BOK's Economic Statistics System (ECOS; http://ecos.bok.or.kr), an integrated statistics system for compiling, analyzing, and disseminating statistics. All ODCs report data electronically via the BOK's DACOS that is an integral component of ECOS.

The existing infrastructure provides for optimal working conditions at the BOK. Adequate safeguards are in place to provide emergency back-up and retrieval of statistical series and updates, if necessary.

\subsubsection{Measures to ensure efficient use of resources are implemented}

Measures to ensure efficient use of resources seem to be adequate. In August of each year, the ESD prepares its budget for the following year, which the BOK's Budget and Management Department (BMD) evaluates. During the year, the program and use of resources are monitored on a quarterly basis. The program is reviewed annually.

The staff performance assessment is conducted twice a year. The outcomes of these assessments determine one of the two salary bonuses received by the staff. Reviews of work processes are carried out periodically. On occasion, outside consultants are used, for instance, to develop statistical compilation systems.

\subsection{Relevance}

\subsubsection{The relevance and practical utility of existing statistics in meeting users' needs are monitored}

KOSTAT regularly monitors users' statistical needs and conveys them to the BOK to improve monetary statistics. The BOK does not maintain any formal users' liaison group for monetary statistics. However, it uses the ECOS website to communicate with users. Users can submit questions and comments about economic statistics at this website. In addition, surveys about users' needs are conducted regularly through this site.

Monthly monetary data are provided and explained to the press by the BOK. When relevant changes (methodological changes, adjustments to reporting procedures, availability of new data, revisions, etc.) occur, the MFST informs users by press releases. On the front page of 
the press release, e-mail addresses and phone numbers are provided in order to receive questions and monitor users' needs. In addition, contact points are provided in all publications and data releases of the $\mathrm{BOK}$. The $\mathrm{BOK}$ is receptive to remarks and requests from the users of its statistics. This has, for instance, resulted in the publication of the document Easy Guide to Understanding Economic Indicators where users can find the basic metadata and information about some procedures for statistics compilation. The BOK regularly participates in statistical meetings and seminars organized by international and regional organizations. It undertakes studies to identify new and emerging data requirements.

\subsection{Other quality management}

\subsubsection{Processes are in place to focus on quality}

The BOK is fully aware of the importance of quality in statistics. To this end, it has made major efforts during the last years to improve data-collection systems, align compilation procedures with international statistical standards, and expand and improve dissemination means.

Quality improvements are a major concern and duty of the BOK staff in charge of compiling statistics, and the staff are always encouraged to improve the quality of statistics. Improvements made are always reported to the managers, and are an important factor in evaluating staff performance.

The Audit Department of the BOK regularly reviews the consistency and accuracy of the disseminated statistics, together with the level of budget expertise of the candidate, and staff are hired following a competitive process. Internal staff promotions are based on relevant skills, expertise, and performance. The BOK encourages staff to participate in seminars and training programs arranged by domestic, regional, and international organizations in order to enhance statistical knowledge. Staff are also encouraged to prepare research papers on statistical issues that are published under their names; seminars and conferences are arranged at which staff and outside experts participate. In addition, the ESD encourages its staff to prepare research papers for circulation within the ESD as a means of knowledge sharing.

\subsubsection{Choices of sources and statistical techniques, as well as decisions about dissemination, are informed solely by statistical considerations}

The choices of sources, statistical techniques, and dissemination of monetary statistics are made freely by the BOK, and informed solely by statistical considerations. The BOK staff are highly professional and make independent decisions on statistical matters.

The report forms used to collect data for compiling monetary statistics are included in the BOK's Manual on Monetary and Financial Statistics Reports (June 2009). The BOK's Explanation of Monetary and Financial Statistics (2008) documents sources, methods, and the classification of accounts used in compiling the monetary statistics published by the BOK. 


\subsubsection{The appropriate statistical entity is entitled to comment on erroneous interpretation and misuse of statistics}

The BOK monitors media coverage of its statistical products daily. Where there is an erroneous interpretation of the monetary statistics, it seeks correction from the media. It also issues its own press releases to correct misinterpretation or misuse of statistics.

\section{Assurances of integrity}

\subsection{Professionalism}

\subsubsection{Statistics are produced on an impartial basis}

The monetary statistics are compiled on an impartial basis. By the Bank of Korea Act, Article 3, the BOK is independent from the government in its operations, and this independence is personally stressed by the highest levels of the BOK. The BOK's governor is appointed for a term of four years and may be reappointed for a single consecutive term (Article 33). There is no external pressure on the BOK with respect to the content or release of the statistics. In general, the terms and conditions under which the BOK produces and disseminates the monetary statistics are in accordance with professional independence and follow strict technical criteria.

The BOK's recruitment process is solely based on the relevant aptitude and expertise of the candidate, and staff is hired following a competitive process. Internal staff promotions are based on relevant skills, expertise, and performance. The BOK encourages staff to participate in seminars and training programs arranged by domestic, regional, and international organizations in order to enhance statistical knowledge. Staff are also encouraged to prepare research papers on statistical issues that are published under their names; seminars and conferences are arranged at which staff and outside experts participate. In addition, the ESD encourages its staff to prepare research papers for circulation within the ESD as a means of knowledge sharing.

\subsubsection{Choices of sources and statistical techniques, as well as decisions about dissemination, are informed solely by statistical considerations}

The choices of sources, statistical techniques, and dissemination of monetary statistics are made freely by the BOK, and informed solely by statistical considerations. The BOK staff are highly professional and make independent decisions on statistical matters.

The report forms used to collect data for compiling monetary statistics are included in the BOK's Manual on Monetary and Financial Statistics Reports (June 2009). The BOK's Explanation of Monetary and Financial Statistics (2008) documents sources, methods, and the classification of accounts used in compiling the monetary statistics published by the BOK. 


\subsubsection{The appropriate statistical entity is entitled to comment on erroneous interpretation and misuse of statistics}

The BOK monitors media coverage of its statistical products daily. Where there is an erroneous interpretation of the monetary statistics, the BOK seeks correction from the media. It also issues its own press releases to correct misinterpretation or misuse of statistics.

\subsection{Transparency}

1.2.1 The terms and conditions under which statistics are collected, processed, and disseminated are available to the public

The Bank of Korea Act, the Statistics Act, and the Banking Act are available on the websites of the BOK (http://www.bok.or.kr), KOSTAT (http://www.kostat.go.kr), and the FSS (http://www.fss.or.kr), respectively. Detailed descriptions of the methodologies and techniques used are presented on the BOK's website and in various statistical publications.

The ESD also maintains an Information Center where users can obtain additional information on the statistics.

\subsubsection{Internal governmental access to statistics prior to their release is publicly identified}

There is no internal government access to monetary and financial statistics prior to their release to the public.

\subsubsection{Products of statistical agencies/units are clearly identified as such}

The BOK's publications and press releases clearly identify the BOK as the publisher by name, logo, and insignia.

\subsubsection{Advance notice is given of major changes in methodology, source data, and statistical techniques}

Advance notice is provided to the press, or through the BOK's and ECOS websites, when the BOK is preparing a major change in methodology, source data, or statistical technique, for instance, to introduce revised monetary aggregates based on the concepts and definitions recommended in the Monetary and Financial Statistics Manual 2000 (MFSM) or when planning to introduce advance release calendars for its statistical products.

\subsection{Ethical standards}

\subsubsection{Guidelines for staff behavior are in place and are well known to the staff}

There are clear ethical guidelines for official statistics in the Guidelines on Compilation and Dissemination of Statistics issued to all staff in September 1999, which is given to all new 
staff including contract employees, and displayed in work areas. Periodically, the Personnel Department will remind staff of aspects of professional behavior.

High ethical standards are expected of, and observed by, the BOK staff. The BOK's Rules of Employment, the Code of Conduct, and the Code of Ethics and Morals provide general employment rules and guidelines for staff behavior. The Code of Ethics and Morals provides guidance on how to address situations such as conflict of interest, improper requests from outsiders, and information disclosure. Article 32 of the Code of Ethics and Morals requires that training be provided to BOK employees at least once a year to facilitate compliance with the ethics code. Such training is provided to all new employees, and familiarity with this document is required of new staff members, including temporary staff.

\section{Methodological soundness}

\subsection{Concepts and definitions}

\subsubsection{The overall structure in terms of concepts and definitions follows internationally accepted standards, guidelines, or good practices}

The methodological framework used by the MFST to compile monetary statistics is broadly based on the guidelines of the MFSM. This represents significant progress compared with the findings of the 2001 Data ROSC that the monetary statistics were then compiled, in general, on the basis of the IMF's Draft Guide to Money and Banking Statistics in International Financial Statistics (December 1984). However, a few minor departures from the MFSM methodology still exist.

The MFST compiles a depository corporations survey (DCS) that is based on the monetary authorities account (MAA), accounts of the commercial and specialized banks, and accounts of the nonbank depository corporations. The MAA (called "central bank" in BOK publications) is based on the consolidation of the balance sheets of the BOK and the Foreign Exchange Stabilization Fund (FESF). The FESF is owned by the central government and has a foreign currency account at the BOK that pays agreed fixed interest; the FESF does not hold foreign assets itself.

The MFST compiles a separate table on reserve money and its components, although the MAA does not explicitly identify the monetary base, as recommended in the MFSM, but focuses on broad money components issued by the BOK. Other asset and liability components of the MAA also differ somewhat from those recommended in the MFSM, e.g., no separate item for Claims on other depository corporations is presented, and instead net claims on ODCs are compiled and presented as "Consolidation adjustment, net."

The MFST also compiles the ODCs survey (ODCS) that covers commercial and specialized banks and nonbank depository corporations. However, this survey is disseminated only through ECOS and is not included in the BOK's monthly statistical publications. These publications present two separate surveys: one for commercial and specialized banks, and one for nonbank depository corporations. 
Following the recommendations of the 2001 Data ROSC mission, the MFST has, since early 2002, been compiling and disseminating revised monetary aggregates and a new DCS that, in general, comply with the MFSM. The main monetary aggregates compiled by the BOK are as follows:

- $\quad$ Reserve money: currency in circulation (same as currency outside depository corporations $^{2}$ ) and BOK liabilities to ODCs in the form of required and excess reserves.

- $\quad$ M1 (narrow money): currency in circulation plus demand deposits and transferable savings deposits of resident nonfinancial corporations, other financial corporations, and households.

- $\quad$ M2 (broad money): M1 plus money market funds, time and savings deposits, deposits in foreign currency, marketable instruments (certificates of deposit (cd), repurchase agreements, cover bills), yield-based dividend instruments (money in trusts, beneficiary certificates), financial debentures, and cash management accounts (CMAs), all held by resident nonfinancial corporations, other financial corporations, and households. Financial instruments with original maturities of more than two years are excluded.

In addition, in 2006 the MFST began releasing a liquidity aggregate $(L)$ and changed the name of the former $M 3$ aggregate into $L f$ comprising the liquidity aggregate of financial institutions. These aggregates include:

- $\quad$ Lf (liquidity of financial institutions): M2 plus financial instruments with original maturities of more than two years (those types included in M2), policy reserves at life insurance companies, and deposits of the Korea Securities Finance Corporation.

- $\quad$ L (liquidity aggregate): Lf plus liquidity instruments issued by central and local governments, certain other financial corporations, and nonfinancial corporations.

\subsection{Scope}

2.2.1 The scope is broadly consistent with internationally accepted standards, guidelines, or good practices

A single definition of broad money is not prescribed in the MFSM, in recognition that national definitions of broad money vary considerably across countries. For each country, the

\footnotetext{
${ }^{2}$ The mission noted that currency in circulation should exceed currency outside depository corporations by the amount of national currency holdings of ODCs, and was informed that these data will be adjusted accordingly.
} 
national definition of broad money is used in determining the institutional units covered by the DCS.

At end-September 2009, the depository corporations sector, as defined in Korea's monetary statistics, comprised the BOK (including the FESF), 50 commercial banks, five specialized banks, seven merchant banking corporations, 14 investment trust accounts of asset management companies, 38 trust companies (commercial banks' trust accounts), 106 mutual savings banks, 1404 mutual credits, 982 credit unions, 1525 community credit cooperatives, 20 securities companies (issuing CMAs), and the Postal Savings. Coverage of the DCS is complete, as it is based on data from all these institutional units. The Postal Savings is properly classified as an ODC; it is an entirely distinct institutional unit with a complete set of accounts, of which only those accounts related to financial intermediation services are included in the aggregate. The mission was informed that there are no ODCs in liquidation in Korea at this time.

Data for securities companies issuing CMAs that provide settlement services are included in DCS starting from July 2009 when the issuance of these types of CMA accounts was authorized by legislation. However, only the CMA accounts and corresponding assets of these institutions are included. This treatment is not in line with the MFSM concept in that the entire balance sheet of a financial institution should be covered in the DCS, if any of the instruments issued by the institution are included in the national definition of broad money. Furthermore, these securities companies also issue repurchase agreements that could be considered substitutes for deposits, although the amounts are small (about 1.8 percent of broad money).

All ODCs report their balance-sheet data to the BOK on a monthly basis. Consistent with the MFSM, the reported data cover the accounts of domestic headquarters and branches. Overseas branches of domestic ODCs are considered as nonresident and are excluded, whereas branches of foreign banks in Korea are regarded as residents and are included.

\subsection{Classification/sectorization}

\subsubsection{Classification/sectorization systems used are broadly consistent with internationally accepted standards, guidelines, or good practices}

Following the MFSM, foreign positions are distinguished from domestic positions on the basis of residency. The definition of residency is broadly consistent with the concept of residence recommended in the MFSM and the Balance of Payments Manual, fifth edition (BPM5), and is provided in the BOK's Manual on Monetary and Financial Statistics Reports (June 2009). This manual provides guidance to ODCs on completing reports for monetary statistics.

Sectorization of domestic positions into economic sectors is largely in line with guidelines outlined in the MFSM and is presented in the DCS as follows: central government, local government, social security organizations, other financial corporations, nonfinancial 
corporations, and households. Nonprofit institutions serving households are included in the entry "households."

Classification of financial instruments in the monetary statistics also largely follows the recommendations of the MFSM. Classification of financial instruments used in the source data for both the BOK's and the ODCs' accounts, in general, is more detailed than the recommendations of the MFSM. All the types of instruments included in M2, except currency and demand deposits, are also classified by original maturity (up to two years and more than two years). However, for some instruments the source data do not provide sufficient detail to allow proper mapping. For instance, there is no distinction in the source data as to whether money-market funds, trust accounts, and cash management accounts are transferable or nontransferable.

Monetary data disseminated through ECOS provide the full range of instrument detail recommended by the $M F S M$, including positions in financial derivatives and advances on insurance premiums (insurance technical reserves). The only exception is the classification of instruments for monetary aggregates. Although the financial instruments presented for monetary aggregates are more detailed than those in the MFSM, some negotiable instruments, such as CDs and financial debentures, etc., are classified as deposits.

Monetary statistics published in the BOK monthly statistical publications do not provide the same range of instrument detail. Positions in financial derivatives and advances on insurance premiums (Insurance technical reserves) are not separately identified. Furthermore, for some major aggregates, such as net foreign assets, net claims on central government, claims on other financial corporations, etc., certain financial instrument components are omitted. Some additional financial instrument detail is provided in supplementary tables, but reconciliation with data in the main surveys is complicated by heterogeneous groupings of financial instruments across the tables.

Repurchase agreements are classified as collateralized loans, and financial derivatives are properly recorded. Repurchase and reverse repurchase agreements are recorded as separate items in the reported balance sheets. Repurchase agreements and reverse repurchase agreements with resident institutions are classified as deposits (with original maturities of up to two years) and loans, respectively, at the level of the DCS, in line with the MFSM. Repurchase and reverse repurchase agreements with nonresidents are classified as foreign liabilities and foreign assets, respectively.

\section{$2.4 \quad$ Basis for recording}

\subsubsection{Market prices are used to value flows and stocks}

All ODCs value financial assets and liabilities on their reported balance sheets in accordance with the Financial Accounting Standards $(F A S)$ and Statements of Korean Accounting Standards $(S K A S)$ issued by the Korea Accounting Standards Board (KASB). These standards are broadly consistent with the International Financial Reporting Standards (IFRS). The KASB has already developed the Korean International Accounting Standards that more 
closely follow the IFRS. Implementation by the ODCs of these new accounting standards is planned for 2011.

In general, ODCs use market prices to value flows and stocks. Article 68 of the FAS requires that assets and liabilities denominated in foreign currencies be done using market exchange rates in effect at the balance-sheet date. The market exchange rate used is the previous business day's trading volume weighted average rate.

SKAS No. 8 (Investments in Securities) requires that traded securities and available-for-sale securities be initially recognized at their acquisition cost and then be valued using market prices, which is consistent with the MFSM methodology. Held-to-maturity securities are recorded initially at acquisition cost, and then valued at amortized cost using the effective interest rate method.

The BOK continues to value its financial assets and liabilities at book value, and assets and liabilities denominated in foreign currency, including positions with the IMF, are revalued every six months (in June and December). Gold is valued at its historical US dollar price, and the US dollar amount is revalued every six months like all the other foreign currency denominated assets.

In line with the recommendations of the MFSM, loans are not adjusted for expected loan losses. Provisions for expected loan losses are recorded as separate entries and are included in Other liabilities.

\subsubsection{Recording is done on an accrual basis}

The $F A S$ and the $S K A S$ require interest to be accrued on a monthly basis, but do not require accrued interest to be incorporated into the underlying financial instrument. This notwithstanding, monetary statistics are produced on an accrual basis consistent with the MFSM. Both the BOK and ODCs record their accounts on an accrual basis, and the accrued interest is presented together with its underlying instrument.

In accordance with the $F A S$ and the $S K A S$, transactions in financial instruments are recorded on the transaction dates.

\subsubsection{Grossing/netting procedures are broadly consistent with internationally accepted standards, guidelines, or good practices}

Source data for monetary statistics are collected and compiled on a gross basis with no netting of claims of a particular transactor against the liabilities to that transactor or group of transactors. Accounts in overdraft are recorded and reported as loans to the corresponding sector. Loans are recorded on a gross basis at nominal values plus accrued interest, with the provisions for loan losses reported as a separate item under Other liabilities.

In the disseminated survey data, claims on the central government and net foreign assets are presented on a net basis, to be useful for analysis, as specified in the MFSM. The underlying data on a gross basis are also disseminated (see also item 2.3.1 above). 
When producing the ODCS, the MFST applies consolidation procedures that are not in line with the MFSM approach. The MFST consolidates the intrasectoral accounts of ODCs, but also consolidates the accounts of ODCs with the BOK. The net consolidation adjustment is presented separately, and besides the consolidation adjustment includes the net claims of ODCs on the BOK. As a result, ODCs reciprocal asset and liability positions are not identified in the ODCS.

Some ODCs in Korea operate so-called "offshore" accounts. These accounts are separate from the institutions' general banking activities, and are used for raising funds and making loans exclusively with nonresidents. The "offshore" accounts are managed and booked by the institutions' head office located in Korea and are included on the balance sheet reported to the BOK, in line with the FAS. The mission was informed that "offshore" accounts of ODCs are now included in the monetary statistics on a gross basis, following the recommendation of the 2001 Data ROSC mission.

\section{Accuracy and reliability}

\subsection{Source data}

\subsubsection{Source data are obtained from comprehensive data collection programs that take into account country-specific conditions}

The MFST collects monthly balance-sheet report forms for the BOK, including the balance sheet of the FESF, commercial and specialized banks, and other nonbank depository corporations. The BMD provides the BOK balance sheet every month. The monthly balance sheet of the FESF is received from the International Department of the BOK.

All financial institutions operating in Korea are licensed by the FSS. The FSS keeps an up-to-date register, to which MFST staff have online access. All ODCs report their monthly balance sheets electronically through the BOK's website via DACOS, in compliance with the BOK's regulations. The report forms for ODCs used by the BOK for monetary statistics compilation are similar, but not identical, to those used by the FSS for prudential supervision. Also, report forms for commercial and specialized banks slightly differ from those for nonbank depository corporations in that the former provide more detailed information. Report forms are being continually evaluated, and revised when needed, to keep them current with market and legislative changes. The report forms were last revised in June 2009.

For certain nonbank depository corporations, such as mutual savings banks, mutual credits, credit unions, and community credit cooperatives, the monthly reports are collected by their respective federations and forwarded to the BOK.

The report forms solicit detailed information on the ODCs' holdings and issuances of financial instruments. Sectoral information on financial instruments is generally sufficient for meeting the MFSM guidelines. The reported balance sheets are prepared by respondents on the basis of accounting records. The BOK does not use supplementary data in compiling the monetary statistics, with the exception of adjustments made for negotiable instruments traded 
in secondary markets to reflect the proper sectoral classification of their non-ODC holders, using information from the KSD database.

Although there are no regular consultations between the BOK and the FSS on the design of report forms for ODCs, extensive consultations take place whenever there is a need to introduce changes.

\subsubsection{Source data reasonably approximate the definitions, scope, classifications, valuation, and time of recording required}

The source data, compiled in accordance with the BOK's Manual on Monetary and Financial Statistics Reports and the KASB's FAS and SKAS, provide a reasonable approximation to the required definitions, classifications, valuations, and timing of recording. The structures of the balance-sheet report forms require provision of highly detailed data for compiling monetary statistics.

The Manual on Monetary and Financial Statistics Reports provides detailed guidance and instructions to respondents on completing the report forms. The MFST updates the manual regularly, along with the revision of reporting forms, and visits ODCs annually to review the accuracy of the classifications of the underlying accounting data on the reported balance sheets.

\subsubsection{Source data are timely}

The MFST receives the BOK and the FESF balance sheets every month, within 10 days after the reference month. The ODCs are required to transmit monthly balance sheets to the BOK by the $20^{\text {th }}$ of the next month, but sometimes the reports from certain ODCs are delayed until the $25^{\text {th }}$ because some institutions, such as mutual savings banks and the Postal Savings, have extensive branch systems. To meet the dissemination deadline, the BOK employs follow-up procedures to ensure timely receipt of ODCs' data by directly contacting the respondents concerned.

\subsection{Assessment of source data}

3.2.1 Source data-including censuses, sample surveys, and administrative records-are routinely assessed, e.g., for coverage, sample error, response error, and nonsampling error; the results of the assessments are monitored and made available to guide statistical processes

Fully computerized procedures in the BOK's data-collection and compiling systems DACOS and ECOS facilitate monitoring of the accuracy of the data reported by individual ODCs. These systems ensure the internal consistency of each institution's data through automated data validation procedures and identify out-of-trend movements. Any such movements, as well as high-value transactions, are verified with the reporting ODCs.

In addition, the MFST cross-checks the data reported by the ODCs against the balance sheets reported to the FSS. As noted earlier, the relevant BOK and FSS staff have mutual online 
access to the databases in each institution. However, no regular cross-checks of interbank positions, or of the positions between the BOK and the ODCs, are carried out.

\subsection{Statistical techniques}

\subsubsection{Data compilation employs sound statistical techniques to deal with data sources}

The potential for processing errors is minimized by using full electronic reporting and processing procedures, as well detailed documentation of the mappings used in compiling monetary statistics from the reported balance sheets. The DCS is based on the actual accounting records of the BOK and the ODCs, and therefore no estimations are necessary. Data reported by the ODCs are complete and the MFST does not need to estimate missing information.

\subsubsection{Other statistical procedures (e.g., data adjustments and transformations, and statistical analysis) employ sound statistical techniques}

To reflect the proper sectoral classification of holders of negotiable instruments traded in secondary markets, such as CDs and financial debentures, the BOK uses primarily the asset side records of the ODCs, cross-checked with the KSD database. Further, for non-ODC holders of these securities, the information from the KSD database is used.

The MFST undertakes seasonal adjustments of the monetary and liquidity aggregates, and of their major components, using a software called BOK-X-12-ARIMA (v0.3). This software was developed based on the X-12-ARIMA procedures of the United States, adapted for elements of the lunisolar calendar that are in effect in Korea.

\subsection{Assessment and validation of intermediate data and statistical outputs}

\subsubsection{Intermediate results are validated against other information, where applicable}

The data reported by the ODCs are cross-checked on a monthly basis with the balance sheets reported to the FSS. The MFST also regularly cross-checks ODCs' security holdings and classifications with the KSD database and survey data from major securities companies. Certain transactions are also cross-checked with the BOK's wire system. As noted earlier, an exclusive network line is available for the MFST staff to access the KSD database and the BOK's wire system.

Regular consistency crosschecks of interbank positions, and positions between the BOK and the ODCs, are not carried out by the MFST, but the mission was provided with aggregated records on these positions and could verify the broad consistency of the positions by main instruments. 


\subsubsection{Statistical discrepancies in intermediate data are assessed and investigated}

The MFST regularly monitors reported data to investigate statistical discrepancies and to ensure data accuracy. If discrepancies in ODC data are identified, the MFST contacts the reporting institution for clarifications.

\subsubsection{Statistical discrepancies and other potential indicators of problems in statistical outputs are investigated}

Procedures are in place to investigate classification and sectorization errors. If errors are detected, the MFST contacts the respondent institution with a request to correct them, and ensures that the root causes of these errors are addressed.

\subsection{Revision studies}

\subsubsection{Studies and analyses of revisions are carried out routinely and used internally to inform statistical processes (see also 4.3.3)}

Normally, monetary statistics are not subject to routine revision studies. DCS data are revised only when mistakes are detected or methodological changes are applied. Material data revisions by reporting institutions are investigated. Revisions because of changes in the methodology are explained in the BOK's methodological publications.

For the BOK data, the MFST analyzes differences between preliminary and final data from time to time.

\section{Serviceability}

\subsection{Periodicity and timeliness}

\subsubsection{Periodicity follows dissemination standards}

The MAA, the ODCS, the DCS, and the monetary aggregates are disseminated on a monthly basis, consistent with the requirements of the SDDS.

\subsubsection{Timeliness follows dissemination standards}

The BOK disseminates the MAA in two weeks after the end of the reference month, in compliance with the SDDS requirement for the central bank survey.

For the DCS, Korea is availing itself of a flexibility option on timelines due to delays in the reporting of some ODCs. Under the flexibility option, the DCS is disseminated not later than six weeks after the end of the reference month.

The timeliness of reporting by the ODCs has improved recently and, as mentioned earlier, all ODCs' reports are usually available by the $20^{\text {th }}$ of the following month. Taking into account that all compilation procedures are automated, in the near future the BOK should be able to 
release the DCS within one month after the end of the reference month, provided that final BOK data also become available within one month. This would enable Korea to graduate from its use of the SDDS flexibility option.

\subsection{Consistency}

\subsubsection{Statistics are consistent within the dataset}

Automated error-checking systems are employed to check the internal consistency of the individual reported data. The disseminated data do not allow cross-checking of positions between the BOK and the ODCs, or among the ODCs, as these positions are not separately identified. Although the consistency of interbank positions and positions between the BOK and the ODCs is not regularly cross-checked by the MFST, these positions are broadly consistent at the aggregate level. The mission was provided with aggregated records on these positions and could verify the consistency of the positions by main instruments. Whereas the mission detected minor differences between the BOK's and the ODCs' positions at the aggregate and main instrument level, larger (but still relatively small) differences were found in the ODCs' internal positions (by about 4 percent on average for August-October 2009) that could partially be attributed to the fact that the exchange of negotiable instruments in secondary markets is not being reflected in the ODCs' balance sheets immediately.

\subsubsection{Statistics are consistent or reconcilable over a reasonable period of time}

Consistent time series for the DCS and its components are available for over eight years. Longer consistent time series are available for the monetary aggregates (for about 18 years). When changes in methodology or compilation techniques are introduced, historical series are reconstructed as far back as reasonably possible. For example, when the definition of monetary aggregates was revised in 2002, new time series were compiled and officially released going back to 1991 .

Brief footnotes to disseminated tables explain the main breaks and discontinuities in time series.

\subsubsection{Statistics are consistent or reconcilable with those obtained through other data sources and/or statistical frameworks}

Monetary data are consistent with the BOP, IIP, and flow-of-fund accounts as the main source for these sets of data as they relate to depository corporations is the monetary statistics.

Bonds issued by the FESF are recorded as foreign liabilities in the MAA and also included in the central government external debt. Net credit to the government based on government accounts in the BOK differs from GFS data published by the MOSF owing to some differences in sectoral classification. These differences, however, are set out and explained in the BOK's Explanation of Monetary and Financial Statistics (2008). 


\subsection{Revision policy and practice}

\subsubsection{Revisions follow a regular and transparent schedule}

The ODCs' data are final when first released, and not subject to revisions, except when mistakes are detected, in which case the revisions are made and explained in footnotes and comments in upcoming releases. BOK data are preliminary at first release, pending the closing of the BOK's books for the reference month. Data become final in about six weeks after the end of the reference month. A timetable for the release of preliminary and final BOK data is provided in ECOS and the Guide to Economic Statistics Compiled by the BOK.

\subsubsection{Preliminary and/or revised data are clearly identified}

Preliminary and revised data are clearly indicated in all BOK publications and data releases, as relevant.

\subsubsection{Studies and analyses of revisions are made public (see also 3.5.1)}

Revisions of monetary aggregates and other monetary data are explained in the BOK's Explanation of Monetary and Financial Statistics (2008) and through footnotes to the corresponding tables in statistical publications.

\section{Accessibility}

\subsection{Data accessibility}

5.1.1 Statistics are presented in a way that facilitates proper interpretation and meaningful comparisons (layout and clarity of text, tables, and charts)

Monetary statistics are disseminated through press releases, the BOK's ECOS website, and through a variety of statistical publications. ECOS provides data at a relatively detailed level, and includes various kinds of tools for data presentation and comparisons, such as tables, charts, and data download. In addition to ECOS, the BOK's monthly Money and Banking Statistics, the Monthly Statistical Bulletin, and the Principal Economic Indicators present tables on monetary statistics at different levels of detail. The Money and Banking Statistics also provides various charts.

Commentaries on developments in the monetary aggregates are presented in press releases. Statistical publications present time series data for six years, with monthly data for the current year. Seasonally adjusted monetary series are also included in the publications and ECOS.

\subsubsection{Dissemination media and format are adequate}

The BOK disseminates monetary data in the hard copy publications mentioned above and in electronic format. All publications are posted on the BOK's website, in ECOS, in electronic format. ECOS provides time series data going back to 1960. 
However, the accessibility to the BOK's ECOS at the moment is somewhat problematic. It encounters a problem that reportedly is affecting computers throughout Korea. The ECOS is based on access through Internet Explorer, which has a so-called "Active X" component that is intended to increase the speed of access to the site. Upon seeking to access the ECOS, users are asked to download a dedicated locally-provided software program. While this software may be cutting-edge in terms of accessing and manipulating data, the "Active X" component on the Internet Explorer apparently prevents it crossing the firewalls that protect users, or leads to security warnings before the software can be downloaded. The BOK is aware of this issue and is working on addressing it. The BOK estimates that the problem will be resolved by 2012 when there will be state-of-the-art browser-free access. In the meantime, however, international users without direct assistance are restricted to obtaining data and metadata from print publications or commercial vendors.

\subsubsection{Statistics are released on a preannounced schedule}

The BOK provides an advance release calendar for a whole year on a no-later-than basis. The exact release date is then announced one week prior to the release, and the statistics are released in accordance with the announced schedule. Besides, an advance release calendar is disseminated through the IMF's Dissemination Standards Bulletin Board (DSBB) (http://dsbb.imf.org/Applications/web/sddsctycatarclist/?strcode=KOR).

\subsubsection{Statistics are made available to all users at the same time}

The BOK releases monetary data to all users simultaneously via press releases and its website. The press is informed in advance of the data to be released, and embargos are imposed on press releases (for about three hours) to prevent early public disclosure.

\subsubsection{Statistics not routinely disseminated are made available upon request}

Users are provided nonconfidential additional information upon request. Additional information can be requested through the contact points included in ECOS and the BOK's Guide to Economic Statistics Compiled by the BOK (last updated in August 2008).

\subsection{Metadata accessibility}

5.2.1 Documentation on concepts, scope, classifications, basis of recording, data sources, and statistical techniques is available, and differences from internationally accepted standards, guidelines, or good practices are annotated

A comprehensive methodological document on monetary statistics called Explanation of Monetary and Financial Statistics (2008) is available in Korean on the BOK's website and is updated regularly. ECOS includes well-structured methodological descriptions in Korean and English. In addition, two summary documents on methodology (see 5.2.2 ahead) are available. Brief methodological notes provided in footnotes accompany all the tables, including explanations related to revisions. 
Access problems through the ECOS are discussed in section 5.1.2 above.

Korea has posted its monetary metadata on the IMF's DSBB since March 1998

(http://dsbb.imf.org/Applications/web/sddsctycatbaselist/?strcode=KOR\&strcat=AAB00). These metadata were last updated in July 2008 and certified in September 2008. The SDDS monetary metadata should be reviewed and updated to reflect the most current compilation practices.

\subsubsection{Levels of detail are adapted to the needs of the intended audience}

The BOK provides different levels of metadata detail to meet various users' needs. In addition to the detailed methodological publication above, the Guide to Economic Statistics Compiled by the BOK, available in Korean and English, and the Easy Guide to Understanding Economic Indicators, in Korean, provide summary explanations for all the datasets compiled by the BOK, including monetary statistics.

\subsection{Assistance to users}

\subsubsection{Contact points for each subject field are publicized}

Contact information (e-mail addresses, and telephone and fax numbers) is widely available in ECOS and is included in the BOK's Guide to Economic Statistics Compiled by the BOK. Detailed information on contact points is also available in press releases.

Other user services, such as access to more detailed data, submission of data requests, queries and comments, are available to all users through ECOS.

\subsubsection{Catalogs of publications, documents, and other services, including information on any charges, are widely available}

A detailed list of all BOK statistical publications, including contact points and other relevant information, is available in ECOS and included in the Guide to Economic Statistics Compiled by the $B O K$. Electronic versions of all these publications can be obtained free of charge from the BOK's website, some available only in Korean. 
Table 5. Data Quality Assessment Framework (July 2003): Summary of Results for Monetary Statistics

(Compiling Agency: Bank of Korea)

\begin{tabular}{|c|c|c|c|c|c|c|}
\hline \multirow{2}{*}{ Element } & \multirow{2}{*}{ NA } & \multicolumn{4}{|c|}{ Assessment } & \multirow{2}{*}{ Comments } \\
\hline & & $\mathbf{O}$ & LO & LNO & NO & \\
\hline \multicolumn{7}{|l|}{ 0. Prerequisites of quality } \\
\hline 0.1 Legal and institutional environment & & $\mathrm{X}$ & & & & \\
\hline 0.2 Resources & & $\mathrm{X}$ & & & & \\
\hline 0.3 Relevance & & $\mathrm{X}$ & & & & \\
\hline 0.4 Other quality management & & $\mathrm{X}$ & & & & \\
\hline \multicolumn{7}{|l|}{ 1. Assurances of integrity } \\
\hline 1.1 Professionalism & & $\mathrm{X}$ & & & & \\
\hline 1.2 Transparency & & $\mathrm{X}$ & & & & \\
\hline 1.3 Ethical standards & & $\mathrm{X}$ & & & & \\
\hline \multicolumn{7}{|l|}{ 2. Methodological soundness } \\
\hline 2.1 Concepts and definitions & & $\mathrm{X}$ & & & & \\
\hline 2.2 Scope & & $\mathrm{X}$ & & & & \\
\hline 2.3 Classification/sectorization & & $\mathrm{X}$ & & & & \\
\hline 2.4 Basis for recording & & & $\mathrm{X}$ & & & $\begin{array}{l}\text { The BOK values its financial assets and liabilities at book } \\
\text { value and revalues foreign currency-denominated assets and } \\
\text { liabilities twice yearly. Consolidation procedures applied for } \\
\text { the ODCS deviate from } M F S M \text {. }\end{array}$ \\
\hline \multicolumn{7}{|l|}{ 3. Accuracy and reliability } \\
\hline 3.1 Source data & & $\mathrm{X}$ & & & & \\
\hline 3.2 Assessment of source data & & $\mathrm{X}$ & & & & \\
\hline 3.3 Statistical techniques & & $\mathrm{X}$ & & & & \\
\hline $\begin{array}{l}\text { 3.4 Assessment and validation of intermediate data and } \\
\text { statistical outputs }\end{array}$ & & $\mathrm{X}$ & & & & \\
\hline 3.5 Revision studies & & $\mathrm{X}$ & & & & \\
\hline \multicolumn{7}{|l|}{ 4. $\quad$ Serviceability } \\
\hline 4.1 Periodicity and timeliness & & & $\mathrm{X}$ & & & Timeliness does not meet the SDDS requirement. \\
\hline 4.2 Consistency & & & $\mathrm{X}$ & & & $\begin{array}{l}\text { No consistency cross-checking of interbank positions and the } \\
\text { ODCs' records against the BOK's records. Bonds issued by } \\
\text { the FESF are included in both monetary statistics and GFS. }\end{array}$ \\
\hline 4.3 Revision policy and practice & & $\mathrm{X}$ & & & & \\
\hline
\end{tabular}


Table 5. Data Quality Assessment Framework (July 2003): Summary of Results for Monetary Statistics (Compiling Agency: Bank of Korea)

\begin{tabular}{|c|c|c|c|c|c|c|}
\hline Element & NA & $\mathbf{O}$ & LO & LNO & NO & Comments \\
\hline \multicolumn{7}{|l|}{ 5. Accessibility } \\
\hline 5.1 Data accessibility & & & $\mathrm{X}$ & & & $\begin{array}{l}\text { Access to the data posted on the BOK's online database } \\
\text { (ECOS) requires the installation of software that may create } \\
\text { computer security concerns particularly for non-Korean users. }\end{array}$ \\
\hline 5.2 Metadata accessibility & & $\mathrm{X}$ & & & & \\
\hline 5.3 Assistance to users & & $\mathrm{X}$ & & & & \\
\hline
\end{tabular}




\section{Recommendations}

\section{High priority}

- In the future, along with the implementation of the GFSM 2001 methodology, consider recording all FESF flows and stocks in the central government accounts. Ensure consistent treatment of the FESF accounts in the monetary statistics, BOP, IIP, and GFS at all stages.

- For monetary statistics purposes value all marketable financial instruments in the BOK balance sheet, including monetary gold, based on market prices, and revalue assets and liabilities denominated in foreign currencies at the end of every month.

- Take necessary actions to be able to disseminate the DCS within one month after the end of the reference month, in order to withdraw the SDDS flexibility option.

- In compiling the ODCS, do not include net claims on the BOK in the consolidation adjustment, but present claims on and liabilities to the BOK on the assets and liabilities side, respectively.

- Introduce regular cross-checking procedures of positions between the BOK and the ODCs, as well as positions among the ODCs.

\section{Other}

- Change the name of the "reserve money" to "monetary base" and align the dissemination components of the central bank survey with those recommended in the $M F S M$, to explicitly identify the monetary base on the liabilities side and the corresponding components on the assets side.

- Compile and disseminate the ODCs in the BOK's statistical publications combining the accounts of the commercial and specialized banks and the nonbank depository corporations.

- Include the entire balance sheet of those securities companies that issue liabilities included in the national definition of broad money in the DCS.

- Group financial instruments included in monetary aggregates and in broad money into the following MFSM-defined instruments: Currency in circulation, Transferable deposits, Other deposits, and Securities other than shares. The more detailed instrument breakdown could continue to be presented under these instruments as sub-items. Classify all negotiable instruments included in monetary aggregates as Securities other than shares.

- Carefully review and update the SDDS monetary metadata to reflect the most current compilation practice 


\section{Balance of Payments Statistics}

\section{Prerequisites of quality}

\subsection{Legal and institutional environment}

\subsubsection{The responsibility for collecting, processing, and disseminating the statistics is clearly specified}

The Bank of Korea (BOK) has responsibility for collecting and compiling balance of payments (BOP), international investment position (IIP), and external debt data. The Bank of Korea Act (May 1950; last amendment in February 2008), in Article 86, assigns responsibility and provides authority to the BOK for collecting and compiling macroeconomic statistics, among those BOP statistics, and for conducting economic research. The Guidelines on Compilation and Dissemination of Statistics (September 1999), prepared by the BOK's Economic Statistics Department (EDS), provides specific guidelines for the compilation and dissemination of statistics. The Foreign Exchange Transactions Act (December 1961; last amendment in January 2009) and bylaws (the enforcement decree and regulation of this $A c t$ ), also provide authority to the BOK for collecting information from individuals, corporations or foreign exchange banks on international transactions for the purpose of compiling BOP statistics. Article 10-2 of the regulation states that the BOK should report the BOP to the Ministry of Strategy and Finance (MOSF) on a monthly basis. Article 42 of the Banking Act (May 1950; last amendment in October 2009) states the terms under which commercial and specialized banks are to submit balance-sheet accounts to the BOK, and that the BOK may publish the reported data. The Statistics Act (January 1962; last amendment in April 2009) specifies all aspects of the production of statistics in Korea. Article 15 describes conditions for the designation of designated statistics-collecting agencies. The BOK's role in compiling and disseminating BOP statistics is recognized by KOSTAT, which, on July 22, 1976, granted the BOK formal approval (authorization number 30108) to disseminate BOP statistics. Article 27 requires statistical agencies, including the $\mathrm{BOK}$, to disseminate the macroeconomic statistics compiled, and their corresponding metadata.

The compilation of BOP statistics is performed by the BOP Team of the ESD. Working arrangements in the BOK for collection and compilation of BOP and IIP data are consistent with the assignment of responsibilities granted by the corresponding legal framework.

\subsubsection{Data sharing and coordination among data-producing agencies are adequate}

Under the Statistics Act, a high-level deliberative body, the National Statistics Committee, has been established, under the chairmanship of the Minister of Strategy and Finance, for the development and improvement of statistical systems as well as the creation, merger, and abolition of similar and overlapping statistics.

Arrangements and procedures exist to facilitate data sharing and coordination between the $\mathrm{BOK}$ and the data-producing agencies. Those arrangements guarantee the timely provision of monthly data to the $\mathrm{BOK}$, including information on exports and imports from the Korea 
Customs Service (KCS), foreign direct investment in kind from the Korea Trade-Investment

Promotion Agency (KOTRA), residents' reinvested earnings from the Export-Import Bank of Korea, foreign purchases and sales of domestic stocks and bonds from the Financial Supervisory Service (FSS), and international aid flows from the Korea International Cooperation Agency (KOICA). Regular meetings are held with the KCS to discuss data reporting and other related issues, and there are occasional contacts with some of the other data producing agencies.

The Statistics Act, in Article 30, guarantees coordination and data sharing among statistics compiling agencies.

\subsubsection{Individual reporters' data are to be kept confidential and used for statistical purposes only}

The Bank of Korea Act states, in Article 42, that BOK staff should not divulge confidential matters to outsiders. Similar provisions are contained in Article 20 of the Articles of Incorporation of the BOK (June 1950, most recently amended December 2003).

The Rules of Employment of the BOK (September, 1954, last amended in April 2009), in Article 6, states the BOK staff should not disclose information obtained while performing their work. BOK staff who violate the Rules of Employment (Article 32) are to be punished with dismissal, suspension, pay cut, or reprimand.

The BOK's Code of Conduct of the BOK (November, 2004, last amendment December 2009) states in Article 23, that a BOK employee shall not disclose to a third party any information acquired in carrying out his/her duty without prior approval. Also, Article 34 states that the Governor can take necessary action to sanction any employee who has materially engaged in an act in violation of the Code of Conduct. Details of the possible sanctions/punishment are to be established by the BOK's Human Resource Department. All staff take a written oath to commit to follow the code of conduct.

The BOK's Code of Ethics and Morals (January 1996; last amendment November 2004) states, in Number 4, that employees shall consider the interest of the BOK before personal interest and shall not disclose any confidential information acquired during work, and shall not use such information in any way other than to perform a given task.

The Guidelines for Compilation and Dissemination of Statistics of the ESD (September 1999), in its Article 2, states that "Employees of the Economic Statistics Department shall protect the collected basic data from unlawful disclosure and in particular confidential information of the data providers should not be allowed for public reading, reprint, or dissemination to those other than the statistic compilers."

The Foreign Exchange Transactions Act, in Article 22, strictly prohibits officials involved in foreign exchange transactions work from divulging information and/or using information for purposes different from those indicated in this legislation; and, in Article 28, states that officials who violate Article 22 of the Act are liable to imprisonment for not more than two 
years and/or a fine of not more than two hundred million Korean won. The Foreign Exchange Transactions Act (in Korean) is posted on the BOK's website.

The Statistics Act, in Article 33, states that data collection and compilation by the statistical agencies must carry a legal guarantee of protection of the confidentiality of individuals' and juristic persons or bodies' information; and the information collected will be used only for statistical purposes. Article 39 states persons who use data for other than statistical purposes or disclose data to others, are subject to imprisonment for not more than three years or a fine of not more than 10 million Korean won. When conducting surveys and inquiring about other statistical issues, the BOP Team of the BOK informs respondents of the confidentiality provisions and the statistical purpose of the data collected and compiled, following the Statistics Act. The Statistics Act is posted on the KOSTAT website.

Also, confidentiality is guaranteed by the following: (i) data sources are restricted to BOK staff who use this information for performing their statistical duties; (ii) access to the BOK building where confidential data are stored is restricted; and (iii) computing systems have security systems, such as passwords.

\subsubsection{Statistical reporting is ensured through legal mandates and/or measures to encourage response}

The BOK has the legal authority to collect data required to compile BOP and IIP statistics, and its collection activity is consistent with this legal authority.

The Bank of Korea Act, Article 87, provides the legal basis for the collection of information for compiling statistics. In the conduct of statistical collections, the BOK explains to survey respondents the importance of the data being sought for policy formulation in order to encourage response, and has found the approach mostly successful. The Act does not prescribe penalties on non-respondents. In practice, the BOK emphasizes courtesy, and effective relations with respondents.

Thus:

- $\quad$ The BOK considers carefully the response burden (by actively pursuing alternative avenues to obtain data, adapting questions to reporters' terminology and record-keeping systems, carefully designing new surveys, closely monitoring response burden, and periodically evaluating existing surveys).

- $\quad$ The BOK provides assistance to respondents in completing and submitting forms.

The Foreign Exchange Transactions Act makes it mandatory for all corresponding respondents, in Article 16, to provide the information on the methods of payments of any transaction between resident and non-resident, and, in Article 18, to provide the information on financial transactions between residents and nonresidents, and on direct investment and acquisition of overseas immovable items or any related transaction. This Act, in Article 19, indicates the penalties, such as the suspension of permission to perform foreign exchange activities, to be applied when a data producer fails to submit information requested, or reports false information. Article 20 indicates the BOK will request the data producers to submit 
pertinent information on foreign exchange transactions. This Article also delegates to the BOK the responsibility of collecting data indicated by this law. Article 32 states that persons who do not provide information or provide false information intentionally are liable to the imposition of a fine of not more than five million Korean won.

Under the Statistics Act, Articles 24, 25, and 26, make it mandatory for public agencies, individuals, corporations, organizations and other entities to report data for statistical purposes to KOSTAT or delegated data compiling agencies. Under Article 41, KOSTAT can impose fines for non-response to reasonable requests. The BOK can ask KOSTAT to levy such penalties on its behalf, but so far has never needed to do so.

\section{$0.2 \quad$ Resources}

\subsubsection{Staff, facilities, computing resources, and financing are commensurate with statistical programs}

Overall, the BOK has highly qualified human resources in relation to the compilation of BOP and IIP statistics. At present, 12 staff members, most of whom have worked many years in this field (some staff for over 10 years), are engaged in the compilation of the BOP and IIP data. The BOP Team also employs seven temporary workers to assist in collecting data. A large part of the information is collected through the Foreign Exchange Information System (FEIS). Seven staff members are in charge of maintaining and improving the FEIS, and 15 staff members check the correctness of information and compile and analyze foreign exchange statistics. Salary levels are adequate to perform current statistical activities, and staff core and turnover are adequate and manageable, respectively.

The BOP Team is equipped with computers, which are connected to the main data sources and internet, and also it has access to software relevant for its collecting and compiling work.

Physical facilities and financial resources appear to be adequate for current BOP and IIP collection, compilation, and dissemination.

The BOK indicates that it will have sufficient human, computing, physical, and financial resources to carry out the prospective migration to the Balance of Payments and International Investment Position Manual, Sixth edition (BPM6).

\subsubsection{Measures to ensure efficient use of resources are implemented}

One of the important management objectives of the BOK is to raise efficiency. In pursing greater efficiency, the BOK assesses each team's tasks annually and provides for an adequate number of personnel. The staff performance assessment, which is based on employees' working performance, is conducted twice a year. The outcomes of these assessments determine one of the two salary bonuses received by the staff. 
In October of each year, the ESD's teams prepare their budgets for the following year, which the BOK's Budget and Planning Department evaluates. During the year, the program and use of resources are monitored on a quarterly basis. The program is reviewed annually.

Reviews of work processes are carried out periodically. On occasion, outside consultants are used, for instance, to develop statistical compilation systems

\subsection{Relevance}

\subsubsection{The relevance and practical utility of existing statistics in meeting users' needs are monitored}

KOSTAT regularly monitors users' statistical needs, including BOP statistics, and conveys the information to the BOK.

Monthly BOP figures are provided and explained to the press by the BOK. When relevant changes (methodological changes, adjustments to reporting procedures, availability of new data, revisions, etc.) occur in the BOP statistics, the BOP Team informs users through ECOS and by press releases. On the front page of the press release, an e-mail address and phone number are provided in order to receive questions and monitor users' needs. In addition, an e-mail address and phone number are provided in all publications and in ECOS. The BOK is receptive to suggestions and requests from the users of its statistics. This has, for instance, resulted in the publication of a document, Easy Understanding of Economic Indicators, where users can find information about the basic metadata and some procedures for statistics compilation. The BOK regularly participates in statistical meetings and seminars organized by international and regional organizations. It undertakes studies to identify new and emerging data requirements.

\subsection{Other quality management}

\subsubsection{Processes are in place to focus on quality}

The BOK is fully aware that quality should be the cornerstone of the statistical processes. To this end, major efforts such as improving collection systems, coordination with compiling agencies, aligning data compilation to international recommendations, and expanding and improving dissemination means have been put in place during the last years. The BOP Team recognizes the trade-offs involved in data compilation, such as between timeliness and accuracy.

The Statistics Act, in Article 11, mandates self-evaluations of the quality of the statistics every year. In addition, Article 9 of the Act, and Article 7 of the Enforcement Decree of the Statistical Act (March 1962; last amendment in June 2008) state that KOSTAT should perform a statistics quality evaluation every five years, including on BOP and IIP data. 


\subsubsection{Processes are in place to monitor the quality of the statistical program}

Mechanisms are in place to ensure increasing quality in the compilation of the BOP and IIP. For instance, some users give feedback to the BOP Team about BOP statistics (the Korea Tourism Organization gives feedback about the travel account of BOP). Other mechanisms include the review and revision of preliminary data, periodic visits to data providers, other periodic reviews to identify steps necessary to maintain quality, assessments of data collection and compilation processes, and cross-checking data sources. Also, access to expert guidance on the quality of statistics and strategies for improving data production is sought to improve the quality of the statistics including compilation and dissemination practices.

\subsubsection{Processes are in place to deal with quality considerations in planning the statistical program}

There are medium- and long-term plans to improve data quality. These plans include actions to improve institutional coverage, additional training, and an ongoing familiarization with the BPM6 analytical framework for compiling BOP and IIP data. They also include feedback from users on quality standards and on new and emerging data requirements, and considerations about resource availability, timeliness, and accuracy and reliability.

\section{Assurances of integrity}

\section{$1.1 \quad$ Professionalism}

\subsubsection{Statistics are produced on an impartial basis}

A culture of professionalism is clearly recognized as essential to the credibility of statistical results. The BOP statistics are compiled on an impartial basis. There is no external pressure on the BOK with respect to the content or release of the statistics. In general, the terms and conditions under which the BOK produces and disseminates the BOP statistics are in accordance with professional independence and follow strict technical criteria. The Bank of Korea Act, Article 3, states that the BOK is independent from the government in its operations.

The BOK's governor is appointed for a term of four years and may be reappointed for a single consecutive term (Bank of Korea Act, Article 33). The BOK's recruitment process is solely based on the aptitude and expertise of the candidate, and staff are hired following a competitive process. Internal promotions of the staff are based on relevant skills, expertise, and performance. The BOK encourages staff to participate in seminars and training programs arranged by domestic, regional, and international organizations in order to enhance statistical knowledge. A separate budget is available to the ESD for these purposes. Article 32 of the Code of Ethics and Morals indicates that the BOK's governor shall provide training to employees, and that such training will be provided at least once a year. Staff are encouraged to prepare research papers on statistical matters that are published under their names; and seminars and conferences are arranged at which staff and outside experts participate. In 
addition, the ESD encourages its staff to prepare research papers for internal circulation within the ESD as a means of sharing knowledge.

\subsubsection{Choices of sources and statistical techniques, as well as decisions about dissemination, are informed solely by statistical considerations}

Choices of data sources and statistical techniques, and decisions about dissemination are taken by the BOP Team solely on statistical considerations. Data sources are selected according to the usefulness and availability of the information to compile sound BOP and IIP. Also, changes to the analytical framework and decisions on dissemination are based solely on statistical grounds. Each year the monthly release date for the BOP is determined by the BOP Team in advance and publicized on the BOK's website. BOP figures are disseminated by press release.

\subsubsection{The appropriate statistical entity is entitled to comment on erroneous interpretation and misuse of statistics}

BOP data are disseminated through regular briefings to the press, along with explanatory materials. The BOP Team maintains an active monitoring system of media relations to help avoid erroneous interpretation and misuse of statistics. The BOP Team monitors press reports after BOP data dissemination, and releases additional explanatory materials as needed.

\subsection{Transparency}

\subsubsection{The terms and conditions under which statistics are collected, processed, and disseminated are available to the public}

The terms and conditions under which statistics are collected, compiled, and disseminated are posted on the BOK' website. The Bank of Korea Act, the Statistics Act, and the Foreign Exchange Transactions Act are available on the websites of the BOK (http://www.bok.or.kr), MOSF (http://www.mosf.go.kr), and KOSTAT (http://www.kostat.go.kr), respectively. Detailed descriptions of the methodologies and techniques used are presented on the BOK's website and in various statistical publications. The ESD also maintains an Information Center where users can obtain additional information on the statistics.

The ECOS, posted on the BOK's website, covers 49 aspects of the BOP statistics, including content, history, raw data, compiling method, quality information, dissemination periodicity, dissemination schedule, dissemination method, confidentiality policy, update date, and contact persons.

\subsubsection{Internal governmental access to statistics prior to their release is publicly identified}

At the scheduled date and time, BOP data are disseminated to the press without embargo. 


\subsubsection{Products of statistical agencies/units are clearly identified as such}

The BOK's publications and press releases clearly identify the BOK as the publisher by name, logo, and insignia. Advance notice is given to the public about major changes in the methodology or other relevant changes that materially affect the BOP, such as improvements in the institutional and transactions coverage.

\subsubsection{Advance notice is given of major changes in methodology, source data, and statistical techniques}

New statistical initiatives were announced by press release on September 24, 2008. Changes in compilation methodology, such as raw data and release items, are included in the press release and explained during the press briefing. These changes are explained in the BOK's publications by footnotes.

When the BPM6 is implemented, the BOK will a make public announcement in advance as was the case when the Balance of Payments Manual Fifth Edition (BPM5) was implemented.

\subsection{Ethical standards}

\subsubsection{Guidelines for staff behavior are in place and are well known to the staff}

The Rules of Employment, the Code of Conduct, and the Code of Ethics and Morals in the BOK prescribe the appropriate behavior of the BOK staff. The Code of Ethics and Morals is circulated each month to the BOK staff to remind them.

\section{Methodological soundness}

\subsection{Concepts and definitions}

2.1.1 The overall structure in terms of concepts and definitions follows internationally accepted standards, guidelines, or good practices

Korean BOP concepts and definitions are broadly consistent with the recommendations of the BPM5 framework. In particular:

- $\quad$ Current, capital, and financial accounts of the balance of payments statement are defined according to the guidelines of the BPM5, and the current account balance is equal (with sign reversed) to the net capital and financial account balance.

- In constructing the balance of payments statement, a double-entry system is applied as a basic principle, and the net residual is embedded in the errors and omissions item.

- A clear distinction is made between the income component and the goods and services components. 
- The financial account provides for a separate recording of transactions in assets and transactions in liabilities.

- $\quad$ The directional principle is applied in recording foreign direct investment.

The data are split up in four main headings:

- $\quad$ Current account: goods and services, income and current transfers.

- Capital and financial accounts: capital transfers and other (that includes information of the acquisition/disposal of nonproduced nonfinancial assets) in the capital account; and direct investment, portfolio investment, financial derivatives, and other investment in the financial account.

- $\quad$ Change in reserve assets.

- $\quad$ Net errors and omissions.

The BOK compiles BOP statistics in accordance with the methodology recommended in the BPM5 since January 1998, and has revised previous data for 1980-97. In March 2003, the BOK released its first annual IIP statistics, for 2001. Since June 2007, the BOK has released quarterly BOP for time series starting in 2002.

The authorities have prepared a plan to migrate to the BPM6. This process will start in 2010, and data compiled using this framework are scheduled to be disseminated in 2012.

Resident institutional units are generally defined in conformity with the BPM5's concepts of economic territory and center of economic interest. The definitions of resident and nonresident are established by the Foreign Exchange Transactions Act, bylaws, and the BOP and IIP Guide. The definition of residents includes (i) any private person who has a domicile or residence in the Republic of Korea, (ii) organizations, agencies, or other equivalent entities located in the Republic of Korea, including branch offices or other offices of nonresidents, and (iii) any foreigner who has stayed in the Republic of Korea more than six months; and the definition of nonresidents includes (i) any private person and any juristic person other than residents, (ii) organizations, agencies, or other equivalent entities located in foreign countries, including foreign branch offices or other offices of residents, (iii) nationals of the Republic of Korea who work in business offices or other offices abroad, and (iv) nationals of the Republic of Korea who have stayed abroad for more than two years. For the compilation of BOP, students who stayed in or out of Korea for more than two years will not change his/her condition of residency if they intend to return to their country of origin.

The center of economic interest of individuals of a household unit remains in the country in which the household is resident.

Following international guidelines, the BOK has adopted the 10-percent criterion for recording direct investment transactions since April 1999. 


\subsection{Scope}

2.2.1 The scope is broadly consistent with internationally accepted standards, guidelines, or good practices

In principle, Korea's BOP statistics cover all resident-nonresident transactions. The data cover the whole economic territory of Korea. However, currently, partial data are compiled on reinvested earnings viz, for the foreign branches of domestic banks, and on foreign currency transactions of enterprises through accounts held abroad. Regarding reinvested earnings, the authorities plan to disseminate time series of these transactions from 2006 onwards with full coverage at the beginning of 2010; and regarding the information about the accounts held abroad, the FEIS already records this information.

Some deviations from the BPM5 framework are clearly identified in public sources.

\subsection{Classification/sectorization}

\subsubsection{Classification/sectorization systems used are broadly consistent with internationally accepted standards, guidelines, or good practices}

The BOP statistics are mostly in line with the classification recommended by the BPM5.

Korean BOP aggregates for selected financial accounts are prepared using a full coverage of institutions and with an institutional breakdown that follows international recommendations. The Foreign Exchange Stabilization Fund is classified as part of monetary authorities.

Government guaranteed external debt transactions are attributed to the institutional sector of the borrower. Public enterprises claims and liabilities are attributed to the private borrowing sector. With regard to transactions, borrowing and lending between direct investors and direct investment enterprises are classified under Foreign Direct Investment (FDI), except when those transactions are between affiliated monetary financial institutions. Also, long-term construction projects are classified under foreign direct investment. Transactions in goods and services by government entities abroad are classified under the standard component "government services not-included-elsewhere." The short-term and long-term attribution of transactions in the other investment component is made according to the original maturity of the financial instrument.

Some departures from the international recommendations are still in place. For instance, reporting on foreign direct investment is based on the Foreign Transactions Act and bylaws, which is believed to cover mostly long-term direct investment in the form of equity and long-term loans. Thus, the foreign direct investment data do not include trade credits and short-term loans with affiliated entities, which are recorded as part of other investment. 


\subsection{Basis for recording}

\subsubsection{Market prices are used to value flows and stocks}

Transactions are valued at market prices.

Transactions reported in the FEIS are converted to US dollars, the unit of account, at the rates prevailing at the time of the transaction; transactions in goods are converted by the KCS using the average exchange rate of the previous week; and monthly data on inward portfolio investment in the domestic stock and bond market, which represent Korean won transactions, are converted to US dollars at daily exchange rates.

The financial flows of banking sector and reserve transactions in foreign exchange are derived from stock data and are adjusted to remove the effects of exchange rate fluctuations.

\subsubsection{Recording is done on an accrual basis}

Merchandise trade statistics are recorded largely according to the time of clearance by customs, except shipbuilding exports which are surveyed and recorded at the time of change of ownership. From 2010, a time series back to 1994 of shipbuilding exports on the basis of stage payments will be disseminated, to be in line with the treatment in the National Accounts. National Accounts statistics have started compiling these data on the basis of stage payments since May 2009.

Portfolio investment and other investment are recorded at the time of change of ownership.

The BOK's BOP and IIP Guide notes that all income, including interest and dividend income, is recorded on a payment basis, which is not in conformity with the BPM5 framework. For transactions of significant amounts in this category the BOP Team makes adjustments to an accrual basis using surveys.

\subsubsection{Grossing/netting procedures are broadly consistent with internationally accepted standards, guidelines, or good practices}

Gross/netting procedures are broadly consistent with the BPM5. Current and capital account transactions are recorded on a gross basis. Financial account transactions are recorded on a net basis, separately for the individual asset and liability components.

The FEIS permits some netting of transactions, and the BOP Team makes adjustments for selected transactions to record them on a gross basis. 


\section{Accuracy and reliability}

\subsection{Source data}

\subsubsection{Source data are obtained from comprehensive data collection programs that take into account country-specific conditions}

The data sources are broadly sufficient to compile major items of Korea's BOP statistics and are under continuous review to guarantee that the data-collection program remains comprehensive. The primary data sources employed by the BOP Team to compile the monthly balance of payments statistics are the trade statistics compiled by the KCS, and the FEIS data collected by the BOK's International Department. These primary data sources are supplemented with information from several secondary data sources. These include administrative data on foreign direct investment in Korea compiled by the Ministry of Knowledge Economy (MKE), data on nonresident sales and purchases of domestic securities compiled by the FSS, the BOK survey on portfolio investment abroad, information on international aid from the Korea International Cooperation Agency, and several surveys in the area of transportation, communication, and construction services and of credit card companies. There is complete coverage of financial institutions in the FEIS. The reporting system permits netting, and the BOP staff adjust the data to a gross basis where they can. The coverage of the secondary data sources is also close to comprehensive. There is comprehensive coverage of administered surveys.

The FEIS is an electronic reporting system that records and classifies all international transactions associated with flows of foreign exchange that result in changes to the foreign exchange banks' foreign currency balance sheets. This system was developed by the BOK for domestic financial institutions to transmit to the BOK information on international transactions and positions. Under the Foreign Exchange Transactions Act, all transactions must be recorded, although transactions below US\$ 10,000 for payments and US\$20,000 for receipts do not require detailed reporting. The FEIS comprises both flows and some stocks statistics. The stock data are for financial institutions: the BOK, deposit money banks, merchant banks, and development institutions. The information collected through the FEIS is shared with other institutions, including the MOSF, the KCS, the National Tax Service, and the Korean Financial Intelligence Unit. Entities such as securities and insurance companies also report data to the FEIS. Also, the FEIS collects some data on external debt of deposit money banks. The BOK regularly performs auditing procedures on the data recorded in the FEIS in addition to the cross-checking options that the system has itself. Users of this system also cross-check and validate data recorded in the FEIS.

Goods data collected by the KCS are the primary source data for goods exports and imports. In addition, the KCS provides data for smuggled goods. The custom data exclude bunker fuel sales to carriers. Data on goods procured in ports are obtained from the Korean National Oil Corporation in a special survey (for exports) and from the FEIS for imports of goods by domestic carries. Migrants' effects are recorded in the customs documents for both exports and imports. 
Service data recorded in the FEIS are the primary source data for services. Surveys of resident airline and shipping companies are the primary data source for transportation services. Some of the transportation items are also derived from the FEIS. Data on travel credits are obtained from the FEIS and supplemented with information obtained from domestic airlines for nonresident expenditures in domestic flights and from credit card companies. Data on travel debits are also obtained from the FEIS and supplemented with information on the credit card companies. Data on communication services are obtained from the FEIS, supplemented with information from a direct survey of telecommunication companies. Data on construction is recorded in the FEIS. Data on fees and commissions associated with nonresident transactions in domestic securities are obtained from estimates using data available on the value of securities trading by nonresidents compiled by the Financial Supervisory Service. Data on government services, n.i.e., are derived from the FEIS and supplemented with information from a special survey on payments to the United States troops based in Korea and the KOICA. The FEIS is the data source for royalties and various business services transactions. Data on other services, i.e., financial services and other business services such as advertisements and services with affiliated companies, come from the FEIS. Merchanting data are obtained using surveys.

Income data source is mainly the FEIS. Investment income receipts and payments are recorded net of any withholding taxes deducted at source. The BOP Team obtains information on financial lease payments from a monthly survey of some airlines and eight shipping companies. In addition, some adjustments are made by the BOP Team's survey to cover interest and dividend receipts in residents' accounts abroad. Reinvested earning data are obtained from surveys of financial and nonfinancial enterprises.

Current transfer data source is mainly the FEIS. In addition, Korea's foreign aid provision in kind is obtained from the KOICA.

Capital Account data sources are the FEIS and the KOICA. Migrants' transfers, including migrants' effects, are recorded in the capital account.

Acquisition/disposal of nonproduced, nonfinancial assets data source is the FEIS.

Direct investment data source is the FEIS for recording outward direct investment, and administrative information from the MKE for recording inward direct investment. In addition to information on equity and loan transactions with foreign direct investors, the reports from the MKE cover imported goods that form part of the direct investor's investment in an enterprise. The BOP Team's survey is used to complement the information indicated above. Data for foreign direct investment in kind are obtained from the KOTRA, and data for reinvested earnings of residents' direct investment overseas are obtained from the Export-Import Bank of Korea.

Portfolio investment data abroad are obtained by the BOP Team's survey, and data on foreign portfolio investment are obtained partly from the FSS and partly from the FEIS. The survey of financial institutions includes data on opening and closing positions in different types of foreign securities, transactions with nonresidents, and other factors contributing to 
changes in the positions data. The securities transactions data do not include any fees and commissions. Data on nonresidents' transactions in the domestic stock-and-bond markets are obtained from the FSS.

Other investment data source is mainly the FEIS for short-term trade credit and for the liability side, and the surveys to large shipbuilding enterprises for long-term trade credit. Several sources are employed to compile data on loan assets. For the monetary authorities, the data are obtained from balance-sheet information, while for central government the data are reported by the Export-Import Bank of Korea, which serves as the government's agent. On the liability side, information on the use of Fund credit and loans is obtained from the International Department. Information on the external loans of general government, banks, and other sectors comes from the FEIS. Flows on account of foreign currency deposits and assets abroad are computed from changes in balance-sheet positions. Bank's transactions are mostly derived from position data submitted by resident banks to the BOK. Data from the BOP Team's survey are also used.

Financial derivatives transaction data sources are the FEIS and the BOP Team's survey. The $\mathrm{BOK}$ is developing a system to collect flows and positions of financial derivatives for 2010.

Capital account data are mainly from the FEIS. Data on migrants' assets in kind are obtained from the KCS.

Reserve assets data are obtained from the BOK's International Department. The data on positions are obtained and transactions are derived from compiling differences in monthly positions in original currencies.

\subsubsection{Source data reasonably approximate the definitions, scope, classifications, valuation, and time of recording required}

The source data for Korea's BOP to a large extent use definitions, scope, classifications, valuations, and times of recording that are broadly in line with the BPM5. The surveys conducted by the BOP Team are designed to adhere to the BPM5 guidelines. Where applicable, adjustment procedures to source data are used to improve the coverage, classification, and timing of the information received by the BOP Team from the FEIS. Several adjustments to goods data are also made for coverage, classification, and timing.

The FEIS provides good coverage of transactions. There is no reporting mechanism to systematically record non-cash transactions in the BOP statistics, such as share exchanges, stock dividends, debt to equity conversions, and arrears. Some information is captured for debt to equity conversions.

\subsubsection{Source data are timely}

Source data for the compilation of monthly BOP statistics are timely. Monthly merchandise trade statistics are available within three weeks after the reference month. Information from the FEIS is also available within three weeks after the reference month. Response to monthly 
surveys is requested within three weeks after the reference month, and the BOP Team conducts follow-ups to ensure the timely receipt of respondents' data.

\subsection{Assessment of source data}

\subsubsection{Source data-including censuses, sample surveys, and administrative records-are routinely assessed, e.g., for coverage, sample error, response error, and nonsampling error; the results of the assessments are monitored and made available to guide statistical processes}

The BOP Team regularly assesses source data and makes supplementary surveys when necessary. Sample surveys are conducted. In the survey of outward portfolio investment transactions, respondents are required to provide a reconciliation of the flows that contributed to the net change in positions between two reporting periods.

Information obtained from the FEIS is comprehensive. High-value or other unusual transactions identified in primary or secondary data sources are queried with individuals or with the agency responsible for the data.

The source data are analyzed for underreporting/misreporting, in particular to check temporal consistency and consistency with related data sources and in the context of revisions. All material changes from available up-to-date data are incorporated into the BOP statement according to a revision cycle.

The accuracy of public sector external debt data, international trade, and other supplementary sources used to compile balance of payments statistics is routinely assessed.

There are no formal requirements for the reporting institutions and in the FEIS to reconcile changes in foreign exchange positions with the reported data. The BOP Team collects data from the FEIS by direct access and by formats that aggregate data. If detailed information from these formats is needed by the BOP Team, the International Department of the BOK provides this information. A summary report of transactions and positions is submitted to the ESD every 10 days, and a detailed one every month.

\subsection{Statistical techniques}

\subsubsection{Data compilation employs sound statistical techniques to deal with data sources}

In the FEIS, compiling procedures minimize processing errors since they are made by computer programs. Adjustments to individual reports are made only when confirmed with the reporters. Sound estimation techniques are employed to adjust data for missing observations in statistical collection. For certain financial items, such as deposits, the stock data are used to derive flows estimates. The flow data are also used to update benchmark data in compiling monthly external debt statistics. 


\subsubsection{Other statistical procedures (e.g., data adjustments and transformations, and statistical analysis) employ sound statistical techniques}

Adjustments and others for goods transactions: several adjustments are made to the trade statistics to improve coverage and timing: survey information is used to construct timing adjustments with respect to petroleum imports delivered outside the customs boundary and for the delivery of shipbuilding exports, which shows a considerable gap between the change of ownership and customs clearance; imports recorded on a c.i.f basis are converted to a c.i.f basis through the application of a factor that is determined on the basis of volume and freight earnings information periodically obtained from KOSTAT, the Ministry of Land, Transport and Maritime Affairs, airline companies, and the Korea Airports Corporation; information is obtained on earnings of domestic shipping lines and insurers from a monthly survey, which is used in conjunction with information on the volume of imported goods to compute the amount of freight and insurance charges to be deducted from imports; adjustments are made in respect of returned goods; and coverage adjustment is included for smuggled exports and imports, based on information provided by the KCS.

Adjustments and others for services: some adjustments are made to the BOP Team's survey in order to record transactions on a gross basis for transportation, insurance, telecommunications, travel, and construction. Data for communication services are collected from the FEIS, adjusted using the BOP Team's survey of telecommunications companies to record communication services on a gross basis. Data for travel services are also collected from the FEIS, and adjusted using the BOP Team's survey of credit card transactions to record travel services on a gross basis. Electronic commerce transactions by credit card, obtained from the KCS, are excluded from travel services, and included in goods transactions. The data on travel receipts are also augmented with information from domestic airlines on passenger fares received from nonresidents for domestic flights (Korean won-denominated transactions). Shipping companies and national airlines are surveyed for data on freight receipts and operational expenses abroad to record transportation services on a gross basis. Data on fees and commissions associated with nonresident transactions in domestic securities are computed by applying commission rates to the value of securities trading by nonresidents compiled by the FSS.

Adjustments and others for direct investment: a methodology has been developed to record construction activity abroad, most of which is classified under direct investment abroad because the contracts typically extend beyond one year. Large construction companies that have large overseas contracts are surveyed for information. The methodology permits a reallocation to direct investment and income of the data on construction services reported in the FEIS.

Adjustments and others for other investments: for most of other investment items, for which end-period data are used, changes between the two periods are taken and adjustments are made for exchange rate changes. The currency composition is estimated by the currency composition ratio at the end of the previous quarter. Nonresidents' portfolio investment on the domestic stock exchange entails changes in nonresidents' Korean won deposits. The BOP Team obtains data for nonresidents' Korean won deposits from the Monetary and Financial 
Statistics Team, and adds it in the "currency and deposits" item. Data for nonresidents' transactions in domestic stock exchanges are obtained from the Financial Supervisory Service, providing Korean won-denominated data. The BOP Team applies the daily exchange rate to translate into US dollars, the accounting unit. For financial leases, the payments are allocated between interest and principal. In the FEIS reporting system, loan assets of financial institutions are recorded net of loan loss provisions. For those loan transactions that are derived from stock data, the BOP Team collects, via a monthly survey, information on loan loss provisions, which it adds back to the stock of loans for purposes of calculating measures of loan transactions that are not influenced by the loss provisions. This provides a better measure of the underlying loan transactions.

\subsection{Assessment and validation of intermediate data and statistical outputs}

\subsubsection{Intermediate results are validated against other information, where applicable}

Data obtained from surveys are checked against information recorded in the FEIS. The number of nonresidents visiting Korea and Koreans traveling abroad are known from records of the Korean immigration Service, and such data are used for validating the travel estimates. Also, travel receipts and payments are checked with the number of travelers from the Korea Tourism Organization. Transportation receipts are checked with the international freight indexes and resident shipping companies' transporting volumes. For inward direct investment, data collected through the FEIS are checked against the MKE sources, and for outward direct investment, data are checking against the Export-Import Bank of Korea. Validation of the direct investment data is performed using cross-checks of flows and stocks of this category. The loans transactions data are cross-checked against balance-sheet information for banks and development institutions. BOP statistics are checked against the foreign exchange receipts and payments statistics, which are compiled in the International Department of the BOK.

\subsubsection{Statistical discrepancies in intermediate data are assessed and investigated}

Merchandise trade and the associated information from the FEIS are reviewed. Direct investment and investment income in the BOP are assessed against the corresponding stock data in the international investment position statistics. Portfolio investment data from the FSS are assessed against the information from the FEIS. Financial derivatives data obtained by the BOP Team are assessed against the information from the FEIS.

\subsubsection{Statistical discrepancies and other potential indicators of problems in statistical outputs are investigated}

The BOP Team monitors the statistical discrepancies in Korea's BOP statistics frequently. When statistical discrepancies become large, the BOP Team investigates and prepares a report on the assessment, with the actions to be taken to reduce or eliminate these discrepancies. 


\subsection{Revision studies}

\subsubsection{Studies and analyses of revisions are carried out routinely and used internally to inform statistical processes (see also 4.3.3)}

Analysis of revisions is undertaken to get an impression of the direction and magnitude of revisions between preliminary and final data. When a new compilation method is introduced, a pilot compilation is made before it is finally accepted, and it is applied to the BOP statistics for the preceding periods as well as for the subsequent periods.

\section{Serviceability}

\subsection{Periodicity and timeliness}

\subsubsection{Periodicity follows dissemination standards}

The BOK disseminates monthly BOP statistics, thereby exceeding the quarterly periodicity prescribed by the SDDS.

\subsubsection{Timeliness follows dissemination standards}

The BOK disseminates preliminary monthly BOP statistics no later than one month after the end of the reference month, thereby exceeding the timeliness of one quarter prescribed by the SDDS.

\subsection{Consistency}

\subsubsection{Statistics are consistent within the dataset}

Korea's quarterly and annual BOP data are derived by aggregating monthly data. The underlying concepts, definitions, and classifications are therefore identical across series of differing periodicity. The net errors and omissions item has shown stability and has been relatively small over time, with the signs having changed.

Financial transactions are reconcilable against changes in the IIP and a table explaining the reconciliation is disseminated on a regular basis. In the data press release, the BOK prepares a table that links BOP and IIP data.

\subsubsection{Statistics are consistent or reconcilable over a reasonable period of time}

Consistent time series are available for BOP statistics.

When the BOK introduces changes in methodology or techniques, historical time series are reconstructed as far back as reasonably possible. When the BOP statistics were aligned to the BPM5 framework at the beginning of 1998, the monthly data were revised back to 1980 and made available in a special publication and on the BOK's website. Consistent historical data 
(since 2003) are published in the Monthly Balance of Payments of the BOK. Additional BOP time series are also presented on the BOK's website. The BOK is aware of the need to explain and document changes on the time series, and when events affect time series, they are annotated and published.

\subsubsection{Statistics are consistent or reconcilable with those obtained through other data sources and/or statistical frameworks}

Korea's BOP data are broadly consistent with national accounts, external debt, IIP, international merchandise trade, and monetary and financial statistics. These datasets are produced by the BOK and the data benefit from internal consultations with relevant teams and reviews within the system of national accounts:

- $\quad$ The BOP data on trade are reconciled with the international merchandise trade data produced by the Foreign Exchange Analysis Team.

- $\quad$ The BOP data are fully reconciled with national accounts statistics.

- $\quad$ The BOP transactions are consistent with the IIP data to the extent that several data flows and position data series are obtained by the BOP Team from the same data sources.

- The BOP components comprising external debt data are consistent, in general terms, with the correspondent external debt position data (which is a subset of the IIP liabilities data).

- The BOP data have no formal reconciliation with government finance statistics, although they use the same data source. Key variables that could be reconciled include external current and capital transfers, and some general government transactions of portfolio investment and other investment accounts (external financing) against the corresponding categories in GFS.

\subsection{Revision policy and practice}

\subsubsection{Revisions follow a regular and transparent schedule}

When a change of over US\$30 million a month is made in the statistics of KCS (customs clearance basis), and when monthly foreign exchange receipts and payments are revised and finalized, the preliminary statistics for that month are revised and released together with the preliminary statistics for the following month. After the first revision, no further revisions are made until the final revision in November or December of the next year. Monthly and annual BOP statistics of the previous year are finally revised and released in November or December, based on finally revised import-export statistics of KCS, foreign exchange receipts and payments, and the annual final raw data of corporations. 
When preliminary data are finalized, they are made public by press release. The reasons for the revisions, such as the availability of updated source data, or revision in related datasets, are described.

\subsubsection{Preliminary and/or revised data are clearly identified}

Preliminary and final data are clearly noted in publications. They are disseminated with the same detail and through the same media.

\subsubsection{Studies and analyses of revisions are made public (see also 3.5.1)}

When the final BOP figures are released, factors contributing to any differences from the preliminary statistics are analyzed. The causes of any revisions are explained in the press release.

\section{Accessibility}

\subsection{Data accessibility}

5.1.1 Statistics are presented in a way that facilitates proper interpretation and meaningful comparisons (layout and clarity of text, tables, and charts)

The BOP statistics are disseminated according to the standard components of the BPM5, and with time series. This dissemination permits identification and comparison of major aggregates of flows. In the Monthly BOP (e-book), which is provided on the website of the BOK about two weeks after the press release, the statistics are presented in a way that facilitates proper interpretation and meaningful comparisons of longer time series. The data are presented in column form in a series of tables that first highlight summary aggregates and then progressively provide additional component detail. The e-book contains six years of annual data and monthly data for 23 months. Longer time series, back to 1980, are available on the BOK's website. The BOK provides bilateral balance of payment statistics, for both current account and capital and financial account, and seasonally adjusted current account statistics. Each year, the March and September issues of the Monthly Bulletin provide an analysis of the data.

The press release contains a short analysis of current-period developments.

\subsubsection{Dissemination media and format are adequate}

The dissemination formats for the BOP statistics are adequate. The BOP data are first published in a press release and made available at the same time on the BOK's Economic Statistics System website (ECOS). An abbreviated version of the press release is made available in English at the same time. The data are later published in the Monthly BOP (e-book) and the Monthly Bulletin. Data back to 1980 are available on ECOS for most series. However, ECOS encounters a problem that reportedly is affecting computers throughout Korea. These systems are based on access to Internet Explorer, which has a so-called "Active 
X" component that is intended to increase speed of access to the site. Upon seeking to access the ECOS, users are asked to download a dedicated locally-provided software. While this software may be cutting-edge in terms of accessing and manipulating data, the "Active X" component on the browser apparently prevents it crossing the firewalls that protect users, or leads to security warnings before the software can be downloaded. The BOK is aware of this issue, and is working to address it. The $\mathrm{BOK}$ estimates that the problem will be resolved by 2012, when there will be state-of-the-art browser-free access. In the meantime, however, international users without direct access to the BOK are restricted to obtaining data and metadata from print publications or by going through commercial vendors.

\subsubsection{Statistics are released on a preannounced schedule}

The BOP statistics are released on schedule according to an advance release calendar, which gives approximate release dates (on a no-later-than basis) one year in advance and the precise release date one week ahead of release. There is a notice in the Monthly Bulletin informing users of statistics that the advance release calendar can be found on the BOK's website and the IMF's website.

\subsubsection{Statistics are made available to all users at the same time}

The data are released simultaneously to all interested users at 8:00 a.m. on the day of the release through the BOK's website and by press release.

\subsubsection{Statistics not routinely disseminated are made available upon request}

Non-published, non-confidential, disaggregated and free-of-charge data are made available upon request. The availability of non-published data and the procedures for obtaining them are made known.

\subsection{Metadata accessibility}

5.2.1 Documentation on concepts, scope, classifications, basis of recording, data sources, and statistical techniques is available, and differences from internationally accepted standards, guidelines, or good practices are annotated

Metadata for BOP data are made public. Extensive documentation (about 50 items) on Korea's balance of payments methodology, data sources, and statistical techniques is available on the BOK's website. Additional information is disseminated in two documents, the BOP and IIP Guide and Easily Understanding Economic Indicators. Also, detailed metadata are posted on the IMF's DSBB. These metadata give adequate information about the meaning of data and methodology used to collect and compile the BOP and IIP. They include information about the concepts, data sources, definitions, classifications, compilation methods, and others. Bridge tables showing the links between source data and the BOP are prepared in the BOP and IIP Guide. Problems of access to metadata deriving from the "Active $X "$ issue are dicussed above. 


\subsubsection{Levels of detail are adapted to the needs of the intended audience}

The BOP metadata provide enough detail for the intended audience.

\subsection{Assistance to users}

\subsubsection{Contact points for each subject field are publicized}

BOK staff are available to answer queries from users by telephone, fax, internet (ECOS), and e-mail, as is stated on the BOK's website. Contact points (name, position, phone number, fax number, address, and e-mail) are listed on the BOK's website. Contact points are also provided on press releases.

5.3.2 Catalogs of publications, documents, and other services, including information on any charges, are widely available

A list of the statistical products produced by the BOK is presented on the BOK's website. The BOK does not charge for using statistical services on the BOK's website, but the Monthly Bulletin is available for a fee. Catalogs of publications (including the Monetary Bulletin) are provided on the BOK's website, where users can buy them. 
Table 6. Data Quality Assessment Framework (July 2003): Summary of Results for Balance of Payments Statistics

(Compiling Agency: Bank of Korea (BOK))

\begin{tabular}{|c|c|c|c|c|c|c|}
\hline \multirow{2}{*}{ Element } & \multirow{2}{*}{ NA } & \multicolumn{4}{|c|}{ Assessment } & \multirow{2}{*}{ Comments } \\
\hline & & $\mathbf{O}$ & LO & LNO & NO & \\
\hline \multicolumn{7}{|l|}{ 0. Prerequisites of quality } \\
\hline 0.1 Legal and institutional environment & & $\mathrm{X}$ & & & & \\
\hline 0.2 Resources & & $\mathrm{X}$ & & & & \\
\hline 0.3 Relevance & & $\mathrm{X}$ & & & & \\
\hline 0.4 Other quality management & & $\mathrm{X}$ & & & & \\
\hline \multicolumn{7}{|l|}{ 1. Assurances of integrity } \\
\hline 1.1 Professionalism & & $\mathrm{X}$ & & & & \\
\hline 1.2 Transparency & & $\mathrm{X}$ & & & & \\
\hline 1.3 Ethical standards & & $\mathrm{X}$ & & & & \\
\hline \multicolumn{7}{|l|}{ 2. Methodological soundness } \\
\hline 2.1 Concepts and definitions & & $\mathrm{X}$ & & & & \\
\hline 2.2 Scope & & & $\mathrm{X}$ & & & $\begin{array}{l}\text { Only partial data are compiled on foreign currency transactions of } \\
\text { enterprises through accounts held abroad and on reinvested } \\
\text { earnings. }\end{array}$ \\
\hline 2.3 Classification/sectorization & & & $\mathrm{X}$ & & & $\begin{array}{l}\text { There are some departures that arise mainly in the classification of } \\
\text { trade credits and short-term loans with affiliated entities (they are } \\
\text { recorded under other investement instead of direct investment). }\end{array}$ \\
\hline 2.4 Basis for recording & & & $\mathrm{X}$ & & & $\begin{array}{l}\text { Income transactions are recorded on a payment basis, they should } \\
\text { be recorded on an accrual basis. }\end{array}$ \\
\hline \multicolumn{7}{|l|}{ 3. Accuracy and reliability } \\
\hline 3.1 Source data & & $\mathrm{X}$ & & & & \\
\hline 3.2 Assessment of source data & & $\mathrm{X}$ & & & & \\
\hline 3.3 Statistical techniques & & $\mathrm{X}$ & & & & \\
\hline $\begin{array}{l}\text { 3.4 Assessment and validation of intermediate data and } \\
\text { statistical outputs }\end{array}$ & & $\mathrm{X}$ & & & & \\
\hline 3.5 Revision studies & & $\mathrm{X}$ & & & & \\
\hline \multicolumn{7}{|l|}{ 4. $\quad$ Serviceability } \\
\hline 4.1 Periodicity and timeliness & & $\mathrm{X}$ & & & & \\
\hline 4.2 Consistency & & $\mathrm{X}$ & & & & \\
\hline 4.3 Revision policy and practice & & $\mathrm{X}$ & & & & \\
\hline
\end{tabular}


Table 6. Data Quality Assessment Framework (July 2003): Summary of Results for Balance of Payments Statistics (Compiling Agency: Bank of Korea (BOK))

\begin{tabular}{|c|c|c|c|c|c|c|}
\hline \multirow{2}{*}{ Element } & \multirow{2}{*}{ NA } & \multicolumn{4}{|c|}{ Assessment } & \multirow{2}{*}{ Comments } \\
\hline & & $\mathbf{O}$ & LO & LNO & NO & \\
\hline \multicolumn{7}{|l|}{$\begin{array}{ll}\text { 5. } & \text { Accessibility }\end{array}$} \\
\hline 5.1 Data accessibility & & & $\mathrm{X}$ & & & $\begin{array}{l}\text { Access to the ECOS database requires the installation of software } \\
\text { that may cause computer security concerns, particularly for non- } \\
\text { Korean users. }\end{array}$ \\
\hline 5.2 Metadata accessibility & & $\mathrm{X}$ & & & & \\
\hline 5.3 Assistance to users & & $\mathrm{X}$ & & & & \\
\hline
\end{tabular}




\section{Recommendations}

- $\quad$ Expand the transactions coverage by including all transactions on reinvested earnings and foreign currency transactions of enterprises through accounts held abroad.

- Improve classification of direct investment transactions by reclassifying data on trade credits and short-term loans of affiliated enterprises.

- Align the basis of recording of income transaction to that recommended by the international standards.

- Maintain coordination across agencies to ensure data consistency during the migration process towards the BPM6 framework.

- In the future, along with the GFSM 2001 methodology, consider recording all FESF flows and stocks in the central government accounts. Ensure consistent treatment of the FESF accounts in the monetary statistics, BOP, IIP, and GFS at all stages. 


\section{APPENDIX I: USERS' VIEWS}

15. An informal survey of the views of users on the macroeconomic statistical data produced by the Korean authorities was conducted by the Fund staff with the assistance of the BOK. ${ }^{3}$ Forty responses were received. Meetings were also held individually with four users. Most users were satisfied with the coverage, periodicity, and timeliness of Korea's economic data, and considered that there had been improvements since the earlier Data ROSC in 2001. In general, these views were consistent with the findings of the mission, and the main areas identified for improvement broadly in line with the proposals being put forward by Fund staff, but a number of additional insights were derived.

16. Overall, users were satisfied with the coverage of official statistics, as well as their periodicity and timeliness, and with the level of detail disseminated. Most respondents found it easy to access the data, and considered the methodology to be sufficiently clear and at an adequate level of detail. Three quarters of respondents accessed official statistics through the official websites. One respondent thought that there was bias in the disseminated data; another suggested that the quality of Korea's statistics was likely to be higher than elsewhere, given that surveys almost invariably get a response rate well in excess of 90 percent, while in many other countries - including those with highly rated statistical systems - the response rate is frequently much lower.

17. While views were broadly positive across most of the datasets, views on the GFS were less favorable. It was the only dataset for which less than a clear majority of respondents was positive about the characteristic of the statistics about which they were being asked. Less than half the respondents considered that the statistics were being disseminated with appropriate timeliness, only a third were aware of the advance release calendar and about half felt government data were released on the dates announced. Around half considered that they could easily access the official statistics, while a third of respondents considered the quality of GFS statistics "better" than those of other countries, which was markedly lower than that for the other data categories (69 percent to 100 percent). ${ }^{4}$

18. As regards proposals for the future, there were few specific requests. Some argued a need for greater explanations on the data. A few asked for the English-language websites to be made as complete as the Korean. Several asked for a seasonally adjusted CPI. ${ }^{5}$ Also, there

\footnotetext{
${ }^{3}$ The users included academics, banks, government agencies, embassies, and financial and economic institutes.

${ }^{4}$ It is worth noting that the respondents were selected by the BOK, which may mean that they were more familiar with the data being compiled by the BOK and less with GFS. The lack of accessibility of GFS data in the past, as detailed above, could probably explain the relatively less favorable views held by users of GFS. If so, the improved accessibility introduced during the mission should help to address the situation.

5 In response, KOSTAT commented that the Price Statistics Division had conducted a study that found the seasonally adjusted CPI did not provide useful information. They further noted that paragraph 13.14 of the Consumer Price Index Manual: Theory and Practice (200) states that "Consumer price indices are, however, not usually seasonally adjusted, although they sometimes are."
} 
were requests for the CPI to be refined to better take into account housing and private education costs. ${ }^{6}$

\footnotetext{
${ }^{6}$ In response, KOSTAT commented that the CPI is released with very detailed information. Following COICOP, there are 19 item indices for housing and 23 item indices for education. Very specific items for housing maintenance and private schools are included.
} 


\section{Appendix II. Summary of the Special Data Dissemination Standard (SDDS)}

The SDDS prescribes the following practices under each of the identified dimensions:

Data dimension (coverage, periodicity, and timeliness)

- The dissemination of 18 data categories, including component detail, covering the four main sectors (real, fiscal, financial, and external) of the economy, with prescribed periodicity and timeliness.

\section{Access dimension}

- The dissemination of advance release calendars providing at least a one-quarter advance notice of approximate release dates, and at least a one-week advance notice of the precise release dates.

- The simultaneous release of data to all users.

\section{Integrity dimension}

- $\quad$ The dissemination of the terms and conditions under which official statistics are produced and disseminated.

- The identification of internal government access to data before release.

- The identification of ministerial commentary on the occasion of statistical release.

- The provision of information about revision and advance notice of major changes in methodology.

\section{Quality dimension}

- The dissemination of documentation on statistical methodology and sources used in preparing statistics.

- The dissemination of component detail and/or additional data series that make possible cross-checks and checks of reasonableness.

SDDS subscribers are required to:

- $\quad$ Post descriptions of their data dissemination practices (metadata) on the IMF's Dissemination Standards Bulletin Board (DSBB). Summary methodologies, which describe data compilation practices in some detail, are also disseminated on the DSBB. 
- $\quad$ Maintain an Internet website, referred to as the National Summary Data Page (NSDP), which contains the actual data described in the metadata and to which the DSBB is electronically linked.

The IMF's staff are monitoring observance of the standard through NSDPs maintained on the Internet. Monitoring is limited to the coverage, periodicity, and timeliness of the data and to the dissemination of advance release calendars.

Source: http://dsbb.imf.org. 


\section{Appendix III. Data Quality Assessment Framework-Generic Framework (July 2003 Framework)}

\begin{tabular}{|c|c|c|}
\hline $\begin{array}{c}\text { Quality } \\
\text { Dimensions }\end{array}$ & Elements & Indicators \\
\hline \multirow[t]{4}{*}{$\begin{array}{l}\text { 0. Prerequisites of } \\
\text { quality }\end{array}$} & $\begin{array}{l}\text { 0.1 Legal and institutional } \\
\text { environment-The environment } \\
\text { is supportive of statistics. }\end{array}$ & $\begin{array}{l}\text { 0.1.1 The responsibility for collecting, processing, } \\
\text { and disseminating the statistics is clearly specified. } \\
0.1 .2 \text { Data sharing and coordination among data- } \\
\text { producing agencies are adequate. } \\
0.1 .3 \text { Individual reporters' data are to be kept } \\
\text { confidential and used for statistical purposes only. } \\
0.1 .4 \text { Statistical reporting is ensured through legal } \\
\text { mandate and/or measures to encourage response. }\end{array}$ \\
\hline & $\begin{array}{l}0.2 \text { Resources-Resources are } \\
\text { commensurate with needs of } \\
\text { statistical programs. }\end{array}$ & $\begin{array}{l}0.2 .1 \text { Staff, facilities, computing resources, and } \\
\text { financing are commensurate with statistical } \\
\text { programs. } \\
0.2 .2 \text { Measures to ensure efficient use of resources } \\
\text { are implemented. }\end{array}$ \\
\hline & $\begin{array}{l}\mathbf{0 . 3} \text { Relevance }- \text { Statistics cover } \\
\text { relevant information on the } \\
\text { subject field. }\end{array}$ & $\begin{array}{l}\text { 0.3.1 The relevance and practical utility of existing } \\
\text { statistics in meeting users' needs are monitored. }\end{array}$ \\
\hline & $\begin{array}{l}\text { 0.4 Other quality } \\
\text { management-Quality is a } \\
\text { cornerstone of statistical work. }\end{array}$ & $\begin{array}{l}\text { 0.4.1 Processes are in place to focus on quality. } \\
0.4 .2 \text { Processes are in place to monitor the quality of } \\
\text { the statistical program. } \\
\text { 0.4.3 Processes are in place to deal with quality } \\
\text { considerations in planning the statistical program. }\end{array}$ \\
\hline \multirow{3}{*}{$\begin{array}{l}\text { 1. Assurances of } \\
\text { integrity } \\
\text { The principle of } \\
\text { objectivity in the } \\
\text { collection, } \\
\text { processing, and } \\
\text { dissemination of } \\
\text { statistics is firmly } \\
\text { adhered to. }\end{array}$} & $\begin{array}{l}\text { 1.1 Professionalism—Statistical } \\
\text { policies and practices are } \\
\text { guided by professional } \\
\text { principles. }\end{array}$ & $\begin{array}{l}\text { 1.1.1 Statistics are produced on an impartial basis. } \\
\text { 1.1.2 Choices of sources and statistical techniques, } \\
\text { as well as decisions about dissemination, are } \\
\text { informed solely by statistical considerations. } \\
\text { 1.1.3 The appropriate statistical entity is entitled to } \\
\text { comment on erroneous interpretation and misuse of } \\
\text { statistics. }\end{array}$ \\
\hline & $\begin{array}{l}\text { 1.2 Transparency_-Statistical } \\
\text { policies and practices are } \\
\text { transparent. }\end{array}$ & $\begin{array}{l}\text { 1.2.1 The terms and conditions under which } \\
\text { statistics are collected, processed, and disseminated } \\
\text { are available to the public. } \\
\text { 1.2.2 Internal governmental access to statistics prior } \\
\text { to their release is publicly identified. } \\
\text { 1.2.3 Products of statistical agencies/units are } \\
\text { clearly identified as such. } \\
\text { 1.2.4 Advance notice is given of major changes in } \\
\text { methodology, source data, and statistical techniques. }\end{array}$ \\
\hline & $\begin{array}{l}1.3 \text { Ethical standards-Policies } \\
\text { and practices are guided by } \\
\text { ethical standards. }\end{array}$ & $\begin{array}{l}\text { 1.3.1 Guidelines for staff behavior are in place and } \\
\text { are well known to the staff. }\end{array}$ \\
\hline
\end{tabular}




\begin{tabular}{|c|c|c|}
\hline $\begin{array}{c}\text { Quality } \\
\text { Dimensions }\end{array}$ & Elements & Indicators \\
\hline $\begin{array}{l}\text { 2. Methodological } \\
\text { soundness } \\
\text { The methodological } \\
\text { basis for the } \\
\text { statistics follows } \\
\text { internationally } \\
\text { accepted standards, } \\
\text { guidelines, or good } \\
\text { practices. }\end{array}$ & $\begin{array}{l}\text { 2.1 Concepts and definitions- } \\
\text { Concepts and definitions used } \\
\text { are in accord with } \\
\text { internationally accepted } \\
\text { statistical frameworks. } \\
\mathbf{2 . 2} \text { Scope-The scope is in } \\
\text { accord with internationally } \\
\text { accepted standards, guidelines, } \\
\text { or good practices. } \\
\mathbf{2 . 3} \text { Classification/ } \\
\text { sectorization—Classification } \\
\text { and sectorization systems are in } \\
\text { accord with internationally } \\
\text { accepted standards, guidelines, } \\
\text { or good practices. } \\
\mathbf{2 . 4} \text { Basis for recording-Flows } \\
\text { and stocks are valued and } \\
\text { recorded according to } \\
\text { internationally accepted } \\
\text { standards, guidelines, or good } \\
\text { practices }\end{array}$ & $\begin{array}{l}\text { 2.1.1 The overall structure in terms of concepts and } \\
\text { definitions follows internationally accepted } \\
\text { standards, guidelines, or good practices. } \\
\text { 2.2.1 The scope is broadly consistent with } \\
\text { internationally accepted standards, guidelines, or } \\
\text { good practices. } \\
\text { 2.3.1 Classification/sectorization systems used are } \\
\text { broadly consistent with internationally accepted } \\
\text { standards, guidelines, or good practices. }\end{array}$ \\
\hline $\begin{array}{l}\text { 3. Accuracy and } \\
\text { reliability } \\
\text { Source data and } \\
\text { statistical techniques } \\
\text { are sound and } \\
\text { statistical outputs } \\
\text { sufficiently portray } \\
\text { reality. }\end{array}$ & $\begin{array}{l}\text { 3.3 Statistical techniques-- } \\
\text { Statistical techniques employed } \\
\text { conform to sound statistical } \\
\text { procedures. } \\
\text { 3.4 Assessment and validation } \\
\text { of intermediate data and } \\
\text { statistical outputs- } \\
\text { Intermediate results and } \\
\text { statistical outputs are regularly } \\
\text { assessed and validated. } \\
\text { 3.5 Revision studies-- } \\
\text { Revisions, as a gauge of } \\
\text { reliability, are tracked and } \\
\text { mined for the information they } \\
\text { may provide. }\end{array}$ & $\begin{array}{l}\text { 3.1.1 Source data are obtained from comprehensive } \\
\text { data collection programs that take into account } \\
\text { country-specific conditions. } \\
\text { 3.1.2 Source data reasonably approximate the } \\
\text { definitions, scope, classifications, valuation, and } \\
\text { time of recording required. } \\
\text { 3.1.3 Source data are timely. } \\
\text { 3.2.1 Source data-including censuses, sample } \\
\text { surveys, and administrative records - are routinely } \\
\text { assessed, e.g., for coverage, sample error, response } \\
\text { error, and nonsampling error; the results of the } \\
\text { assessments are monitored and made available to } \\
\text { guide statistical processes. } \\
\text { 3.3.1 Data compilation employs sound statistical } \\
\text { techniques to deal with data sources. } \\
\text { 3.3.2 Other statistical procedures (e.g., data } \\
\text { adjustments and transformations, and statistical } \\
\text { analysis) employ sound statistical techniques. } \\
\text { 3.4.1 Intermediate results are validated against other } \\
\text { information, where applicable. } \\
\text { 3.4.2 Statistical discrepancies in intermediate data } \\
\text { are assessed and investigated. } \\
\text { 3.4.3 Statistical discrepancies and other potential } \\
\text { indicators or problems in statistical outputs are } \\
\text { investigated. } \\
\text { 3.5.1 Studies and analyses of revisions are carried } \\
\text { out routinely and used internally to inform statistical } \\
\text { processes (see also 4.3.3). }\end{array}$ \\
\hline
\end{tabular}




\begin{tabular}{|c|c|c|}
\hline $\begin{array}{c}\text { Quality } \\
\text { Dimensions }\end{array}$ & Elements & Indicators \\
\hline $\begin{array}{l}\text { 4. Serviceability } \\
\text { Statistics, with } \\
\text { adequate periodicity } \\
\text { and timeliness, are } \\
\text { consistent and } \\
\text { follow a predictable } \\
\text { revisions policy. }\end{array}$ & $\begin{array}{l}\text { 4.1 Periodicity and } \\
\text { timeliness-Periodicity and } \\
\text { timeliness follow internationally } \\
\text { accepted dissemination } \\
\text { standards. } \\
\text { 4.2 Consistency_Statistics are } \\
\text { consistent within the dataset, } \\
\text { over time, and with major } \\
\text { datasets. } \\
\text { 4.3 Revision policy and } \\
\text { practice-Data revisions follow } \\
\text { a regular and publicized } \\
\text { procedure. }\end{array}$ & $\begin{array}{l}\text { 4.2.1 Statistics are consistent within the dataset. } \\
\text { 4.2.2 Statistics are consistent or reconcilable over a } \\
\text { reasonable period of time. } \\
\text { 4.2.3 Statistics are consistent or reconcilable with } \\
\text { those obtained through other data sources and/or } \\
\text { statistical frameworks. } \\
\text { 4.3.1 Revisions follow a regular and transparent } \\
\text { schedule. } \\
\text { 4.3.2 Preliminary and/or revised data are clearly } \\
\text { identified. } \\
\text { 4.3.3 Studies and analyses of revisions are made } \\
\text { public (see also 3.5.1). }\end{array}$ \\
\hline $\begin{array}{l}\text { 5. Accessibility } \\
\text { Data and metadata } \\
\text { are easily available } \\
\text { and assistance to } \\
\text { users is adequate. }\end{array}$ & $\begin{array}{l}\text { 5.1 Data accessibility- } \\
\text { Statistics are presented in a } \\
\text { clear and understandable } \\
\text { manner, forms of dissemination } \\
\text { are adequate, and statistics are } \\
\text { made available on an impartial } \\
\text { basis. } \\
\text { 5.2 Metadata accessibility- } \\
\text { Up-to-date and pertinent } \\
\text { metadata are made available. } \\
\\
\text { 5.3 Assistance to users-- } \\
\text { Prompt and knowledgeable } \\
\text { support service is available. }\end{array}$ & $\begin{array}{l}\text { 5.1.1 Statistics are presented in a way that facilitates } \\
\text { proper interpretation and meaningful comparisons } \\
\text { (layout and clarity of text, tables, and charts). } \\
\text { 5.1.2 Dissemination media and format are adequate. } \\
\text { 5.1.3 Statistics are released on a preannounced } \\
\text { schedule. } \\
\text { 5.1.4 Statistics are made available to all users at the } \\
\text { same time. } \\
\text { 5.1.5 Statistics not routinely disseminated are made } \\
\text { available upon request. } \\
\text { 5.2.1 Documentation on concepts, scope, } \\
\text { classifications, basis of recording, data sources, and } \\
\text { statistical techniques is available, and differences } \\
\text { from internationally accepted standards, guidelines, } \\
\text { or good practices are annotated. } \\
\text { 5.2.2 Levels of detail are adapted to the needs of the } \\
\text { intended audience. } \\
\text { 5.3.1 Contact points for each subject field are } \\
\text { publicized. } \\
\text { 5.3.2 Catalogs of publications, documents, and other } \\
\text { services, including information on any charges, are } \\
\text { widely available. }\end{array}$ \\
\hline
\end{tabular}




\section{Appendix IV. Results of Korea's User Survey [December 2009]}

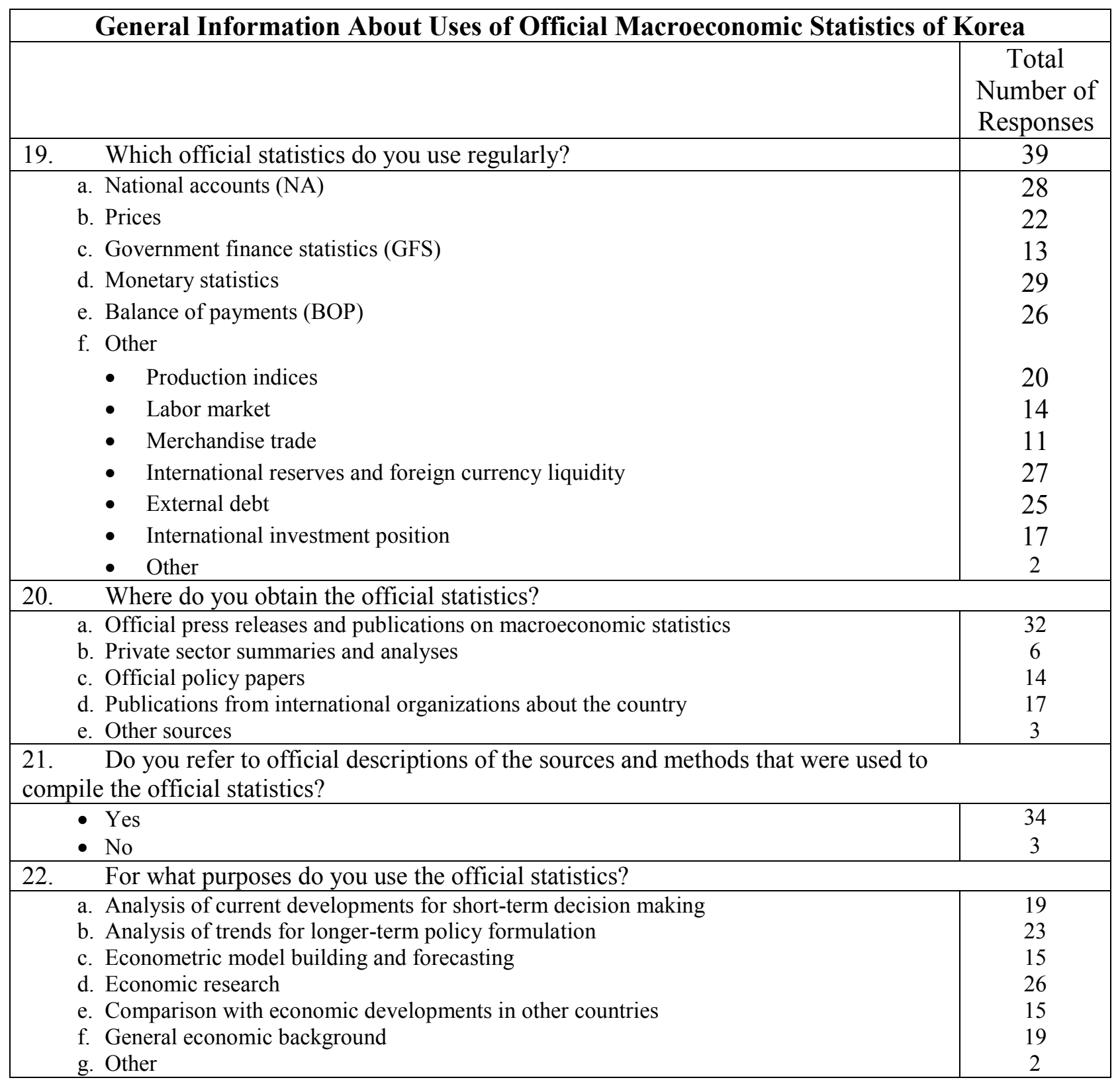




\section{Appendix IV. Results of Korea's User Survey (December 2009)}

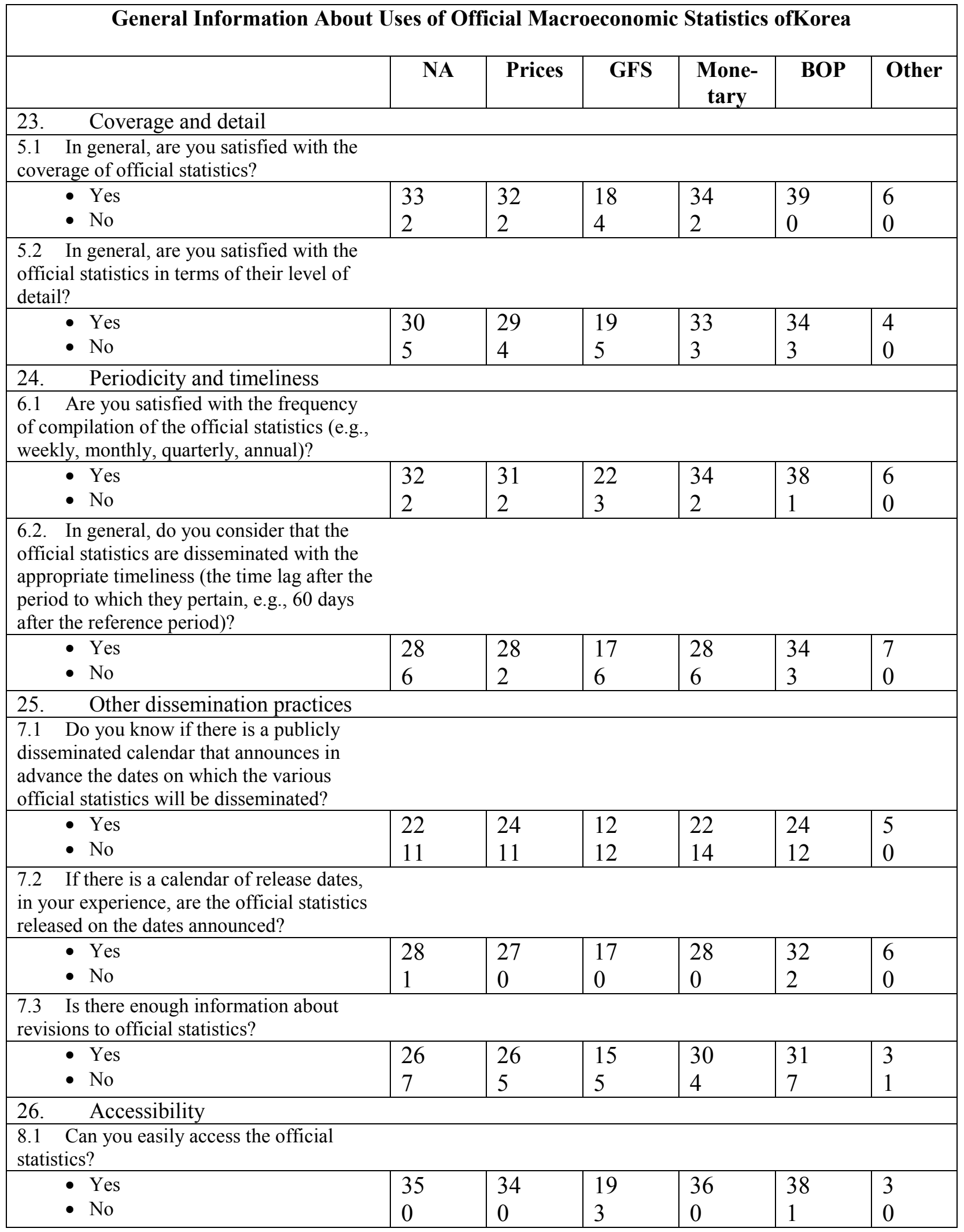




\section{Appendix IV. Results of Korea's User Survey (December 2009)}

\begin{tabular}{|c|c|c|c|c|c|c|}
\hline \multicolumn{7}{|c|}{ General Information About Uses of Official Macroeconomic Statistics ofKorea } \\
\hline & NA & Prices & GFS & $\begin{array}{c}\text { Mone- } \\
\text { tary }\end{array}$ & BOP & Other \\
\hline \multicolumn{7}{|l|}{$\begin{array}{l}8.2 \text { Can you easily access information } \\
\text { pertaining to official statistics you use } \\
\text { (explanatory notes, methodological } \\
\text { descriptions, reference concerning concepts, } \\
\text { classification, statistical practice)? }\end{array}$} \\
\hline $\begin{array}{l}\text { - Yes } \\
\text { - No } \\
\end{array}$ & $\begin{array}{l}29 \\
6\end{array}$ & $\begin{array}{l}31 \\
4\end{array}$ & $\begin{array}{l}17 \\
5\end{array}$ & $\begin{array}{l}28 \\
8\end{array}$ & $\begin{array}{l}30 \\
9\end{array}$ & $\begin{array}{l}3 \\
0\end{array}$ \\
\hline & Yes & No \\
\hline \multicolumn{5}{|l|}{$\begin{array}{l}8.3 \text { Is the above information on } \\
\text { methodology sufficiently clear and at an } \\
\text { adequate level of detail to be useful to you? }\end{array}$} & 28 & 5 \\
\hline \multicolumn{7}{|l|}{$\begin{array}{l}8.4 \text { How do you get access to official } \\
\text { statistics? }\end{array}$} \\
\hline \multirow[t]{2}{*}{$\begin{array}{l}\text { - Official releases } \\
\text { - Hard copy publications } \\
\text { - Data specifically requested } \\
\text { - Official website } \\
\text { - Other } \\
\text { - E-mail requests }\end{array}$} & & & & & $\begin{array}{l}17 \\
11 \\
5 \\
28 \\
5 \\
5\end{array}$ & \\
\hline & NA & Prices & GFS & $\begin{array}{c}\text { Mone- } \\
\text { tary }\end{array}$ & BOP & Other \\
\hline \multicolumn{7}{|l|}{ 27. Overall assessment } \\
\hline \multicolumn{7}{|l|}{$\begin{array}{l}9.1 \text { In your opinion, is the underlying } \\
\text { methodology of official statistics sound and } \\
\text { appropriate? }\end{array}$} \\
\hline $\begin{array}{l}\text { - Yes } \\
\text { - No } \\
\end{array}$ & $\begin{array}{l}33 \\
0 \\
\end{array}$ & $\begin{array}{l}32 \\
2\end{array}$ & $\begin{array}{ll}18 \\
3\end{array}$ & $\begin{array}{l}35 \\
0\end{array}$ & $\begin{array}{l}38 \\
0\end{array}$ & $\begin{array}{l}3 \\
0\end{array}$ \\
\hline \multicolumn{7}{|l|}{$\begin{array}{l}9.2 \text { In general, do you consider the official } \\
\text { statistics to be unbiased and accurate? }\end{array}$} \\
\hline $\begin{array}{l}\text { - Yes } \\
\text { - No }\end{array}$ & $\begin{array}{l}33 \\
1\end{array}$ & $\begin{array}{l}34 \\
1\end{array}$ & $\begin{array}{l}20 \\
3\end{array}$ & $\begin{array}{l}34 \\
1\end{array}$ & $\begin{array}{l}36 \\
1\end{array}$ & $\begin{array}{l}4 \\
0\end{array}$ \\
\hline \multicolumn{7}{|l|}{$\begin{array}{l}9.3 \text { How would you compare the quality } \\
\text { of official statistics of the country with those } \\
\text { of other countries in the region? }\end{array}$} \\
\hline $\begin{array}{l}\text { - Better } \\
\text { - Same } \\
\text { - Worse } \\
\end{array}$ & $\begin{array}{l}25 \\
6\end{array}$ & $\begin{array}{l}24 \\
8\end{array}$ & $\begin{array}{l}10 \\
11\end{array}$ & $\begin{array}{l}25 \\
8\end{array}$ & $\begin{array}{l}26 \\
8\end{array}$ & $\begin{array}{l}4 \\
0\end{array}$ \\
\hline $\begin{array}{l}9.4 \text { How do you assess the overall quality } \\
\text { of the official statistics? } \\
\text { ( } 1 \text { rated as poor and } 5 \text { as excellent) }\end{array}$ & 4.2 & 4.2 & 4.0 & 4.2 & 4.1 & 4.8 \\
\hline
\end{tabular}

NA = National Accounts; Prices refers to: CPI (Consumer Price Index) and PPI (Producer Price Index);

GFS $=$ Government Finance Statistics; Monetary $=$ Monetary Statistics; and BOP $=$ Balance of Payments Statistics 